
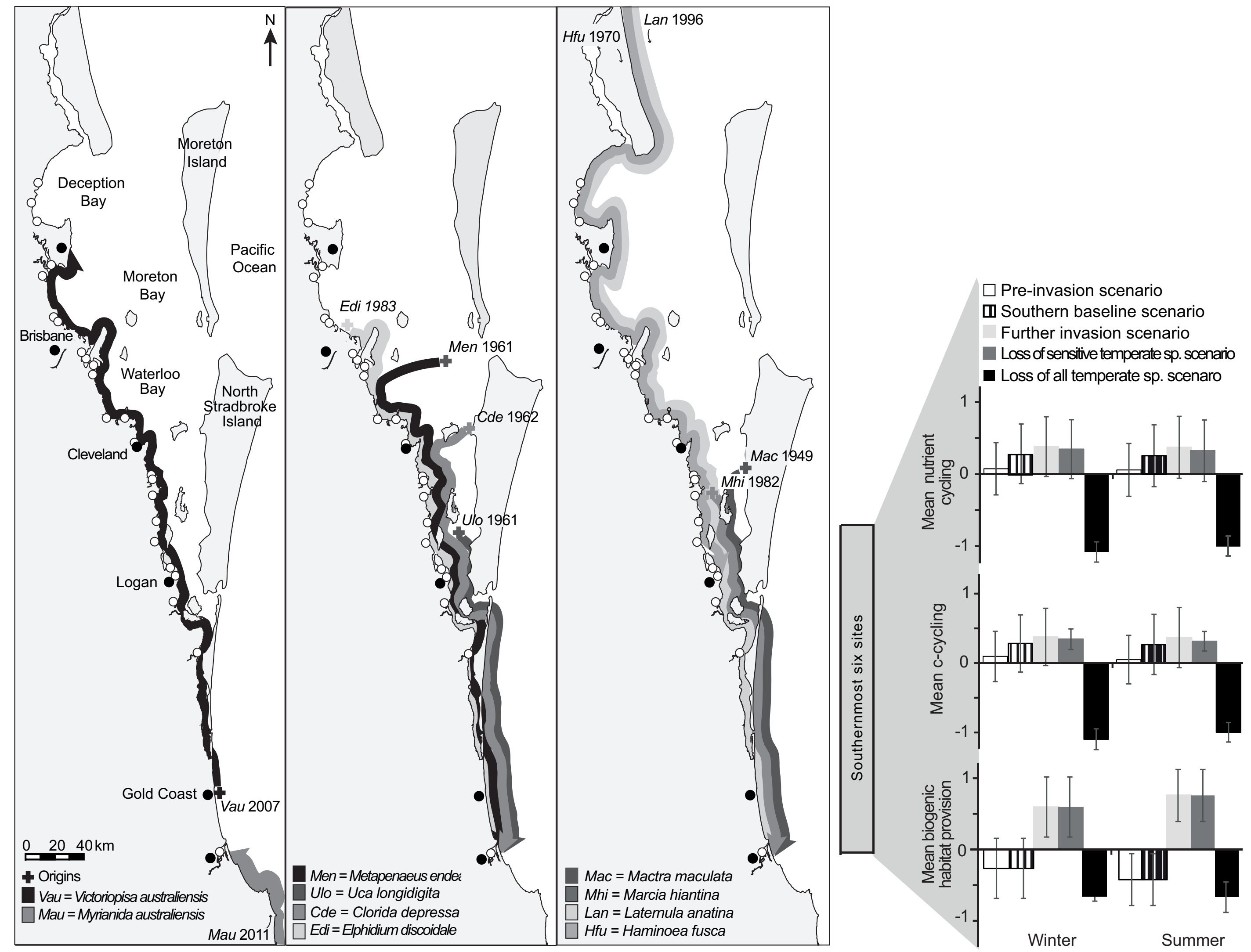

Caswell et al. 2019 Graphical abstract 


\title{
Influence of climate-induced biogeographic range shifts on mudflat ecological functioning in the subtropics
}

\author{
Bryony A. Caswell ${ }^{1,3,}{ }^{,}$, Navodha G. Dissanayake ${ }^{1,2}$, Christopher L. J. Frid ${ }^{2}$
}

${ }^{1}$ Environmental Futures Research Institute, Griffith University, Gold Coast, Parklands Drive, QLD 4222, Australia

${ }^{2}$ School of Environment and Sciences, Griffith University, Gold Coast, Parklands Drive, QLD 4222, Australia

${ }^{3}$ Department of Geography, Geology and Environment, University of Hull, Hull HU6 7RX, UK

${ }^{*}$ Corresponding author: $\underline{\text { b.a.caswell@hull.ac.uk }}$

\section{Manuscript length: $₫ 8100$}

References: 118

Figures: six

Tables: Three

Appendices: six figures and 12 tables

\section{Abstract}

A growing volume of evidence shows that the broad-scale biogeographic redistribution of species is occurring in response to increasing global temperatures. The present study documents poleward movements of up to eight species of nominally 'tropical' macroinvertebrates (molluscs, polychaetes, crustaceans and foraminifera) from intertidal mudflats on the south east coast of Australia. The speed of movement was comparable with that for Australian marine fauna generally, but was particularly fast for worms and molluscs ( $\left.70-300 \mathrm{~km} \mathrm{decade}^{-1}\right)$ and may be facilitated by the southward flowing East Australia Current. Further, two temperate taxa appear to have extended their ranges northwards. Changes in species biogeographic ranges raises questions surrounding the response of ecological processes within the altered and novel species combinations, including processes that underpin valuable ecosystem services. Using biological traits analysis to investigate how the observed species range changes might have impacted mudflat ecosystem functioning, and to predict the possible impacts of further poleward movements of tropical taxa. Our models suggest the changes to date, and those likely to occur in the near future, are within the envelope whereby ecological functioning is maintained by functional compensation and redundancy within the mudflat assemblage. However, in the most extreme scenario the replacement of temperate by tropical taxa resulted in major changes 
in ecological functioning with potential impacts on nutrient cycling and C-cycling, undermining the

Keywords: climate change; ecosystem services; infauna; functional compensation, biological potential of these mudflats to continue to deliver critical ecosystem services. The widespread nature of biogeographic range shifts and the value of coastal systems should add further weight to calls for global action to mitigate global temperature change. traits; novel assemblages

\section{Introduction}

Global average temperatures have risen $>1{ }^{\circ} \mathrm{C}$ since the 1900 s and are predicted to rise a further 1.1$4.8^{\circ} \mathrm{C}$ under most climate scenarios (RCP4.5 and above) by the end of the century (IPCC, 2014). Forecasting the responses of marine ecosystems to these changes is limited not only by uncertainties surrounding such predictions, but also by regional variations in environmental changes and ecological responses (IPCC, 2014; Poloczanska et al., 2013), differences in species biology and behaviour (Deutsch et al., 2015; Nagelkerken et al., 2016; Poloczanska et al., 2013; Wethey et al., 2011) and synergies between the effects of different anthropogenic pressures (e.g. fishing and pollution; Deutsch et al., 2015; Nagelkerken et al., 2016; Rijnsdorp et al., 2009). One consequence of warming is the global redistribution of taxa, with some displacement, contraction and expansion of species biogeographic ranges (Pecl et al., 2017; Poloczanska et al., 2016) leading to the formation of 'novel species combinations'. That is assemblages which comprise, as yet, unobserved combinations of taxa (Alexander et al., 2015). For marine taxa the reported rates of biogeographic shifts are highly variable ( 10-400 km decade $\left.{ }^{-1}\right)$ (Parmesan and Yohe, 2003; Poloczanska et al., 2016; Sorte et al., 2010). A recent meta-analysis found rates of $72 \pm 13.5 \mathrm{~km}^{\text {decade }}{ }^{-1}$ for 360 marine species across a range of taxonomic groups at the poleward or 'leading' edge of their biogeographic distributions (Poloczanska et al., 2013). This is compared with $6.1 \pm 2.4 \mathrm{~km}$ decade $^{-1}$ (Poloczanska et al., 2013) to $17.6 \pm 2.9 \mathrm{~km}$ decade $^{-1}$ for terrestrial taxa (Chen et al., 2011). Przeslawski et al. (2012) assessed 311 marine invertebrates using rigorous criteria and found $37 \%$ had robust evidence for poleward shifts of 3.8$8.9 \mathrm{~km}$ decade $^{-1}$. Variations in the reported rates probably result from differing physiology and dispersal abilities of taxa, regional environmental variations and the more restrictive criteria used by Przeslawski et al. (2012).

Whatever the mechanism driving species range shifts these taxa can have significant, positive and negative, impacts on the recipient marine communities that are similar to those for introduced non- 
native invasive species (Pecl et al., 2017; Sorte et al., 2010). Species arrivals may have no detectable impacts on the established assemblages (Zwerschke et al., 2018) or change may be catastrophic (Katsanevakis et al., 2014; Ling, 2008; Scheffer et al., 2001) for example the decline or extirpation of native species (Cheung et al., 2009; Landschoff et al., 2013; Pereira et al., 2010). The recipient communities are also subjected to changing temperatures, which may alter their abundance or distribution. Species vary in their thermal tolerance (Sunday et al., 2012) and it is likely that sensitive taxa will be lost first from an established community while the assemblage is being colonised by incoming taxa with higher thermal tolerances. The dynamics of species interactions, e.g. competition and predation (Alexander et al., 2015; Poloczanska et al., 2013), within novel assemblages may differ and so too might ecological functioning and service delivery. Sorte et al. (2010) identified eight biogeographic shifts which affected marine ecosystem processes including nutrient cycling, competition, herbivory, predation and disease dynamics. For example, the sea urchin Centrostephanus rodgersii extended its range from temperate New South Wales to eastern Tasmania where its intensive grazing negatively impacted the macroalgal communities. This loss of biogenic habitat contributed to declines in macrofaunal diversity (Ling, 2008). Poleward shifts, of 57-801 km, for $>30$ species of tropical reef fish are impacting functional dynamics on temperate reefs by grazing important habitat-forming kelp species in New South Wales (Fowler et al., 2017; Vergés et al., 2016). Northward shifts of boreal fish are changing food-web dynamics in the Barents Sea, benthic-pelagic coupling has strengthened and competition with resident taxa has led to declines in fish and mammal abundance and body condition (Bonebrake et al., 2018; Kortsch et al., 2015). Similar changes are predicted for Arctic benthos due to shifts in larger, faster-growing molluscs from the Bering Sea (Vermeij and Roopnarine, 2008). The formation of novel assemblages and changes in species interactions will ultimately lead to changes in the ecosystem functioning (Alexander et al., 2015). The biological traits of species can be used to better anticipate functional changes which seem to be critical predictors of system responses to 'invasion' (Alexander et al., 2015; Kortsch et al., 2015; Kristensen et al., 2014).

Intertidal soft sediment habitats such as mudflats deliver a range of ecosystem services (Crowe and Frid, 2015), including the production of food, fuel and construction materials, and the protection of coastal communities from storm surges and flooding (Barbier et al., 2011; Himes-Cornell et al., 2018). The ecosystem services provided by intertidal systems such as estuaries and mudflats are estimated to be US $\$ 5.2 \times 10^{12} \mathrm{y}^{-1}$ (in 2007) globally, with a further US $\$ 24.8 \times 10^{12} \mathrm{y}^{-1}$ (in 2007) from tidal marshes and mangroves (Costanza et al., 2014). Macrofaunal communities inhabiting soft sediments make important contributions to the ecological functions that underpin these ecosystem services, e.g. 
facilitating effluxes of nutrients from sediments that support primary production or sequestering carbon and so mitigating ocean acidification and anthropogenic warming. Therefore, future changes in species biogeographic distributions that impact ecological functioning as a result of warming may have major impacts on the livelihood and economies of coastal communities.

Subtropical regions are a key area of focus for identifying changes in species distributions, where the arrival of tropical taxa and/or loss of temperate taxa become apparent as their ranges expand or contract (Bonada et al., 2007; Davie and Phillips, 2010; Endean et al., 1956). The present study examined changes in the distribution of macroinvertebrates in subtropical mudflats throughout SE Queensland. Generally, information on the biodiversity and taxonomic composition of soft-sediment invertebrate assemblages in SE Queensland are sparse (Davie and Phillips, 2010) with work focussing on sandy shores (Barnes and Hamylton, 2016), northern Queensland (Dittmann, 1996, 2002; Inglis and Kross, 2000) or subtidal benthos (Eertman and Hailstone, 1988; Poiner, 1977; Young and Wadley, 1979). This study provides new data on mudflat macrofaunal assemblages in Moreton Bay, and considers changes in species distributions, and the implications of the observed and future variations for the traits, and so ecological functioning, of these economically important habitats.

\section{Materials and Methods}

\subsection{Field site and macrofaunal sampling}

A total of 24 intertidal mudflats (comprising > 10\% silt and clay) were sampled throughout SE Queensland from Deception Bay $\left(27.15^{\circ} \mathrm{S}\right)$ in the north to Tallebudgera Creek $\left(28.11^{\circ} \mathrm{S}\right)$ in the south (Fig. 1A-B, Appendix Table A.1)(Dissanayake et al. 2019). All mudflats were bordered by mangroves and showed little evidence of direct anthropogenic impact. This region (referred to herein as SE Queensland) is of recognised ecological value, being designated a RAMSAR wetland (Department of Environment and Science, 2019). The sampling sites occupy the northern part of the 'Tweed Moreton ecoregion' and so are near to the boundary (at $\left.25^{\circ} \mathrm{N}\right)$ between the Temperate Australasian and Central Indo-Pacific biogeographic marine realms (Spalding et al., 2007). As such it represents an important faunal transition between tropical and temperate latitudes (Davie and Phillips, 2010; McPhee, 2017). The southern boundary of the 'Tweed Moreton ecoregion' (Spalding et al., 2007) is delimited by the 132 point where the southward flowing East Australia Current meets the northward Tasman Sea Current (between $30-32^{\circ} \mathrm{S}$ ) and is deflected offshore (Dambacher et al., 2012). 
Sampling was conducted once in winter (July-August 2016) and once in summer (January-February 2017). At each site, five box cores $(25 * 25 \mathrm{~cm}$ to $11 \mathrm{~cm}$ sediment depth) were collected from the midshore (approx. 2-5 cm above port datum) for infauna. A minimum of $2 \mathrm{~m}$ distance was maintained between box core samples. Sediments were sieved in situ over $0.5 \mathrm{~mm}$ mesh and the residues were preserved in $90 \%$ ethanol containing Rose Bengal stain. Samples were kept at $4^{\circ} \mathrm{C}$ and returned to the laboratory for identification and enumeration. Given the lower density, mobility and heterogeneous distribution of large epifauna, they were not expected to be adequately represented within the box core samples. Thus, epifauna were collected, adjacent to the infaunal sampling locations, from the upper $20 \mathrm{~cm}$ of sediment within three $0.5 \times 0.5 \mathrm{~m}$ quadrats (with raised sides providing a barrier against fast-moving animals), and were sieved over $2 \mathrm{~mm}$ mesh. The retained fauna were preserved

To explore biogeographic patterns in species and trait composition the 24 sampling sites were grouped according to three criteria (Fig. 1); (i) sites to the north and south of Cleveland, (ii) four equal- 
sized groups ordered north to south, and (iii) the northernmost and the southernmost six sites. Differences between water circulation patterns to the north (open bay) and south of Cleveland (many large islands inhibit water flow) provided a rationale for the latitudinal subdivision of mudflats (McPhee, 2017). Site groupings (ii) and (iii) were objectively divided based on latitude, with classification (iii) representing the two ends of the latitudinal gradient. Given the potential for complex environmental gradients in Moreton Bay, we carefully examined the ordinations for potential patterns in the species composition that would not be detected by statistical comparisons between the selected geographic groupings (i-iii). We concluded that no such patterns existed (Appendix Fig. B2).

The published biogeographic ranges of each of the taxa sampled were obtained from the Atlas of Living Australia (ALA, 2018) and the Ocean Biogeographic Information Systems (OBIS, 2018), these databases contain information from a series of museum records. For each species the apparent range change between the most recently documented occurrence (ALA, 2018; OBIS, 2018) and the most northerly or southerly sampled occurrences were estimated using the difference in degrees of latitude $\left(1^{\circ}\right.$ latitude $\left.=110 \mathrm{~km}\right)$ between the two. Subsequently each taxon was classified based on their published biogeographic ranges (ALA, 2018; OBIS, 2018) as either tropical, temperate or cosmopolitan. The taxa were assigned to one of six categories (A-F) based on their historic distribution or that recorded in this study. A. Tropical species that have extended their range to the southernmost six mudflats sampled in SE Queensland (range shifters, Fig. 1C-D). B. Tropical species that occur throughout SE Queensland. C. Tropical species that currently only occur in the northernmost sites of SE Queensland. D. 'Robust' temperate species whose current range extends throughout SE Queensland, and E temperate species that are sensitive to temperature change (i.e. did not occur in the northernmost six mudflats). The 'cosmopolitan taxa' formed group F. For the purposes of this study cosmopolitan taxa are those that were distributed throughout tropical, temperate and subtropical climatic zones along Australian coastlines only (cf. Hutchings and Kupriyanova, 2018). This restricted definition is used because these records have been confirmed by Australian taxonomists and so are not confounded with other morphologically similar taxa (Przeslawski et al., 2012). Based on their biogeographic distribution three species and the polygeneric taxa (Nematoda and Nemertina) were characterised as cosmopolitan.

\subsection{Effects of climate change on the ecological functioning of} mudflats: Simulating taxonomic and trait change 
The observed changes in species biogeographic ranges were used as the basis for simulating five scenarios of changes in species composition of the mudflat fauna. The implications of past and further climate induced range shifts on mudflat ecosystem functioning were explored using biological traits analysis. Each scenario was derived from the macrofaunal assemblages at the southernmost six mudflats, with scenario 1 being the present or 'baseline' state (1), and for the remaining four scenarios (Table 2) taxonomic composition was manipulated as follows.

- 1. Southern baseline: the present assemblage from the southernmost six mudflats.

- 2. Pre-invasion: the tropical range shifting species (observed in the 24 mudflats sampled in the present study) were removed from the baseline community.

- 3. Further invasion: Tropical taxa that were absent from the southernmost six assemblages were added to the baseline at their mean densities found at the northernmost six sites.

- 4. Loss of sensitive temperate taxa: The most sensitive temperate taxa i.e. those absent from the northernmost six sites (suggesting they had reached the physiological limits of their distribution) were removed from the scenario 3 assemblage.

- 5. Loss of all temperate taxa: All temperate taxa were removed from the scenario 3 assemblage.

Analyses were performed on both unconstrained and constrained data. In the latter case all of the simulated assemblage data were standardised to the same total density to aid comparisons between scenarios. This emphasises the influence of changing species compliment rather than the size of the assemblage (Table 2). For each simulated assemblage the corresponding biological trait matrices were multiplied by the constrained and unconstrained densities to generate the biological trait composition for each scenario.

The impacts of climate-induced biogeographic range shifts on three ecological functions were investigated: nutrient cycling, C-cycling (food web dynamics) and biogenic habitat provision. In coastal seas nutrient cycling is strongly coupled with benthic processes that regenerate nitrogen compounds from sediments, this can provide $20-100 \%$ of the annual $\mathrm{N}$ requirements for water column primary production (Blackburn, 1986; Heinen and McManus, 2004). Macrofaunal communities also transport, transform and store carbon within an ecosystem, and may contribute $11-43 \%$ of total benthic community respiration (Hyndes et al., 2014; Piepenburg et al., 1995; Van Oevelen et al., 2006). This organic C-cycling is driven by food-web dynamics (ingestion, respiration, production) and reproductive processes. Infaunal and epifaunal macrofauna also provide structures (e.g. emergent tubes, mussel/oyster beds) creating habitat for species that require hard substrates, and they provide 
physical protection and refugia (Buhl-Mortensen et al., 2010). Further discussion of these processes and rationale for the determination of these indices (Table 1) is addressed in Appendix B.

Two models were used to explore the implications of species losses and gains from the southernmost mudflat assemblages. Model A included only those trait modalities thought to make meaningful contributions to each of the functions, and these were assigned a weighting of 1 (Frid and Caswell, 2016; Table 1). An additional model (Model B) employing differential weightings, to better reflect our, partial, understanding of the contribution of different trait modalities to particular functions, was also developed although it is not considered further herein (Appendix Tables A.2 and B.10, Fig. B.6).

\subsection{Data analyses}

Firstly, the abundances for all infaunal and epifaunal samples were converted to density per $\mathrm{m}^{2}$. The epifaunal and infaunal data were combined, and in instances where epifaunal taxa occurred in both box cores and the $0.5 \times 0.5 \mathrm{~m}$ quadrats the mean densities from the quadrats were used as they were more reliable for mobile epifauna. The mean and median number of individuals, species richness, Shannon-Weiner diversity and Pielou's evenness were calculated for each site for the two seasons separately, and for the three biogeographic groups (i)-(iii). Median values were compared between sites and groups using the Mann-Whitney $U$ test or Kruskal-Wallis test (SPSS v.25, IBM).

Bray Curtis similarities were calculated from log $(x+1)$ transformed pooled species densities (per $\left.\mathrm{m}^{2}\right)$ from each site (for the replicate box cores and quadrats, as described above). For biological trait composition the species-traits (determined as described in Section 2.2) were multiplied by the species densities to produce a trait modality by site matrix. Bray-Curtis similarities were calculated on untransformed biological traits data. Differences in species and biological trait composition were explored between seasons, biogeographic groups (Section 2.3), and range shift scenarios (Section 2.4) using non-metric multidimensional scaling (nMDS), Analysis of Similarities (ANOSIM) and the similarity percentage routine (SIMPER). The delivery of ecological functioning under the five range shift scenarios were compared using one-way ANOVA, and differences in trait modalities were compared using t-tests. Differences in the trait profiles of the taxa were compared between climatic zones, based on their distribution (A to F, Table 2), using ordination (nMDS and ANOSIM). The similarity percentage (SIMPER) routine was used to identify the trait modalities that contributed to the dissimilarities between groups, and the abundances of the modalities were compared using t-tests. Multivariate 
analyses were completed using Primer 6 Beta (Plymouth Routines in Multivariate Ecology Research Ltd).

\section{Results}

\subsection{Macrofaunal assemblages of mudflats in southeast Queensland}

A total of 3047 individuals were retrieved in the summer and 1800 were observed in winter across the 24 sites sampled in SE Queensland (from 120 box core samples; Mann-Whitney $U$ test, Z = -3.629, p<0.001, Fig. 2A). In the summer 50 taxa were recorded while in the winter there were 46, with the polychaete Platynereis antipoda, the bivalve Paratapes undulatus and the gastropods Recluzia johnii and Nassarius coronatus being absent during the winter. In both seasons 10 taxa contributed to 70\% of the cumulative macrofaunal density in the assemblage (Appendix Table B.1). In summer the suspension feeding bivalve Hiatula alba dominated, followed by the polychaetes Barantolla lepte and Aglaophamus australiensis. Whereas in winter the crabs Mictyris longicarpus and Macrophthalmus setosus dominated. Mudflat assemblage species composition significantly differed between winter 2016 and summer 2017 (ANOSIM, global $R=0.076, p=0.004$, Fig. 2B) with an average SIMPER dissimilarity of $\sim 52 \%$. Given the marked seasonal differences in the mudflat assemblages, for the remainder of the analyses the summer and winter assemblages were considered separately.

\subsection{Biogeographic variations in the species composition of mudflat assemblages}

Overall, northern mudflats appeared to have higher macrofaunal densities, diversity and evenness than those to the south, however they did not significantly differ between mudflats in any of the three biogeographic comparisons (i-iii; Fig. 1B) in either season (Kruskal Wallis test, $p<0.05$ in all cases; Appendix Fig. B1). Macrofaunal species composition did not significantly differ between mudflats north and south of Cleveland (one way ANOSIM; winter global $R=-0.001, p>0.05$; summer global $R$ $=0.011, p>0.05$ ) nor between the four groups of mudflats on a north-south gradient (ANOSIM, winter global $R=-0.035, p>0.05$; summer, global $R=0.057, p>0.05$ ) (Appendix $B$ ). Despite the lack of significant differences in macrofaunal densities and diversity between the northernmost and southernmost six mudflats (comparison iii), species composition significantly differed between these mudflats in summer (ANOSIM, global $R=0.272, p=0.015,55 \%$ dissimilar, Fig. 3B), but not winter (global $R=0.065, p>0.05$, Fig. $3 A$ ). Five taxa, the polychaetes $A$. australiensis and M. dakini, the 
bivalves $H$. alba, M. hiantina and the gastropod $H$. fusca each contributed $>4 \%$ to the SIMPER dissimilarity between the northernmost and southernmost six sites (Fig. 3).

300

In summer, the assemblage at the southernmost sites was comprised mostly of taxa with temperate affinities and were dominated by the bivalve H. alba and the polychaete A. australiensis, but only A. australiensis occurred in significantly higher densities in the south compared to the north ( $t$-test, $t(10)$ $=0.923, p=0.017$, Fig. 3E). M. dakini also occurred in higher densities in the south although it did not significantly differ (t-test, $p>0.05$; Table 3, Fig. 3E). Four temperate taxa, the shrimp Alpheus richardsoni, the polychaetes Trypaea australiensis, Sthenelais boa and Helograpsus haswellianus, and three tropical taxa the stomatopod Clorida depressa, the gastropod R. johnii and the decapod Uca longidigita were present in the southernmost mudflats but were absent from the northernmost sites. The northernmost assemblage was dominated by the tropical bivalve M. hiantina which occurred at significantly higher density than in the south ( $t$-test, $t(10)=-1.991, p=0.040)$. Density of the tropical gastropod $\mathrm{H}$. fusca was five-fold higher in the north (Fig. 3E), although it did not significantly differ (ttest, $\mathrm{p}>0.05$; Table 3, Fig. 3E). Five tropical taxa the bivalves Mactra maculata, P. undulatus, Lutraria impar, the brachiopod Lingula anatina and the decapod Tubuca polita occurred in the northernmost assemblages, but were absent from the southernmost mudflats.

Of the total pool of 50 taxa recorded in SE Queensland mudflats 50\% were classified as temperate, $40 \%$ were tropical and 10\% were 'cosmopolitan' taxa (i.e. widely distributed in both zones) based on their known occurrences (ALA, 2018). According to the documented species distributions (ALA, 2018; OBIS, 2018), five taxa the polychaetes $H$. fusca, Prionospio queenslandica, Eurysyllis tuberculata, Sternaspis scutata, and the bivalve Laternula anatina had previously only been recorded once in the greater SE Queensland region (ALA, 2018; OBIS, 2018; Table 3). Three species had previously only been recorded once in the study area (Table 3).

Ten taxa had wider biogeographic distributions throughout SE Queensland than had previously been documented (Table 3). Up to eight tropical taxa exhibited range shifts, the gastropod $\mathrm{H}$. fusca, the bivalves L. anatina, M. maculata, M. hiantina, and the crustaceans Metapenaeus endeavouri, C. depressa and $U$. Iongidigita, and the foraminifera Elphidium discoidale extended their ranges southwards shifting on average $146 \pm 66 \mathrm{~km}$ (Table 3, Fig. 1B). The relatively small difference in the biogeographic range of the stomatopod Clorida depressa since 1998 (Table 3) may simply result from 
new records due to greater sampling effort. The foraminifera Elphidium discoidale may exhibit a shift of $381 \mathrm{~km}$ since 1983, but this is also uncertain, as it may be confounded by subspecies Elphidium discoidale var. multiloculum (Narayan and Pandolfi 2010). Two temperate taxa also changed distribution, the polychaetes V. australiensis, and M. australiensis which shifted $85 \mathrm{~km}$ and $374 \mathrm{~km}$ northwards (Table 3), respectively. The shifts ranged from $6 \mathrm{~km}$ up to $477 \mathrm{~km}$, and the fastest shifters were H. fusca, L. anatina and M. australiensis which have all shifted $>100 \mathrm{~km} \mathrm{decade}{ }^{-1}$ (Table 3).

Trait modality richness of the macrofaunal assemblage did not significantly differ (Appendix Table B.4) between the mudflats; (i) north and south of Cleveland, (ii) in the four groups along the north to south gradient or (iii) at the northernmost and southernmost six sites. Overall, most macrofaunal taxa were short lived (1-2 years), intermediate sized (> $5 \mathrm{~cm}$ ), unattached, free moving, habitat modifiers which made burrows, and had planktotrophic larval development (Appendix Fig. B.4). Although taxa

\subsection{Taxa trait modality profiles}

The trait modality profiles for taxa with tropical, temperate and cosmopolitan geographic distributions significantly differed (ANOSIM, global $R=0.143, p=0.002$, Fig. 4A), with those for tropical taxa differing from those for temperate taxa $(R=0.149, p=0.003$; average SIMPER dissimilarity $~ 60 \%)$. More temperate taxa had body-sizes $>50 \mathrm{~mm}$, and vermiform body shapes with no exoskeleton, contrastingly tropical taxa typically had more rectangular-subrectangular body shapes and were generally smaller and had exoskeletons. The trait profiles of cosmopolitan taxa did not differ from the tropical or temperate taxa (pairwise ANOSIM, $p>0.05$ ). 
To explore these differences in greater detail the taxa were further categorised based on their occurrences within the 24 mudflats sampled and their reported biogeographic range. The trait profiles of macrofauna significantly differed between the six biogeographic (A-F, Table 3 ) categories of taxa

364 (ANOSIM, global $R=0.223, p=0.001$, Fig. 4B). Pairwise ANOSIM showed the trait profiles of temperate taxa occurring across all 24 mudflats significantly differed from those of: tropical species occurring across all 24 sites (pairwise ANOSIM, R =0.199, $\mathrm{p}=0.012$ ), tropical species present at all but the southernmost 6 sites $(R=0.518, p=0.003)$ and tropical range shifters $(R=0.299, p=0.003)$. A total of 18 trait modalities contributed to $>50 \%$ of the cumulative SIMPER dissimilarity between the trait profiles of taxa in these four categories (Fig. 4C). The main differences between the trait profiles of temperate species (D) and those from the other three categories $(A-C)$ was the greater incidence of vermiform body shapes and lack of body armour (Mann-Whitney $U$ test, $p<0.05 ;>50 \%$ contribution to dissimilarity; Fig. 4C, Appendix B). Whereas, tropical taxa (B-C) had more rectangular shaped bodies, and tropical taxa absent from the southernmost sites had more 0.5-1 mm thick body armour $(p<0.05)$. Tropical species which occurred throughout SE Queensland were typically 10-30 mm body size whereas the other three groups (A, C, E) were comprised of taxa $>50 \mathrm{~mm}$ body size. Significantly less of the temperate taxa were suspension feeders (Mann-Whitney $U$ test, $p<0.05$ ) and significantly more were deposit feeders $(p<0.05)$ compared to the tropical range shifters. There were also significantly more deposit feeding temperate taxa (Mann-Whitney $U$ test, $p<0.05$ ) than tropical taxa absent from the southernmost sites (Fig. 4C, Appendix Table B.5). These differences in trait profiles are consistent with those between all tropical and all temperate taxa.

\subsection{Simulations of species, traits and functional change}

ANOSIM identified significant differences in the taxonomic composition of the simulated assemblages (or 'scenarios') using unconstrained species abundances during both seasons (ANOSIM, winter global $R=0.362, p=0.001$; summer global $R=0.401, p=0.001$, Fig. 5A-B). Pairwise ANOSIM showed both the winter and summer taxonomic composition of scenario 5 significantly differed from all other scenarios (SIMPER dissimilarity 61-81\%); and, in summer scenario 1 differed from scenario 4, and scenario 2 differed from scenarios 3 and 4 (SIMPER 47-49\% dissimilar; Appendix Table B.7). The biological trait composition significantly differed in winter (ANOSIM, global R=0.127, $p=0.05$, Fig. 5A) and summer (ANOSIM, global $R=0.187, p=0.004$, Fig. 5B), and similar to taxonomic composition the traits of the scenario 5 assemblage significantly differed from all other scenarios (pairwise ANOSIM, p <0.01; Appendix B). Fourteen to seventeen of the 45 trait modalities contributed to $70 \%$ of the cumulative SIMPER dissimilarity between the trait composition for scenario 5 and all of the 
other scenarios in both winter and summer $(p<0.05)$. All modalities except one were significantly more abundant in scenarios 1-4 (Appendix Table B.8). Thus, despite the changed density of 4-8 taxa in scenarios 1-4 (Table 2) only scenario 5 consistently differed in species and trait composition across both seasons (Appendix Table B.8 and B.9).

The estimates for nutrient cycling significantly differed between the winter scenarios (ANOVA, winter: $F=2.868, p=0.04)$, however post-hoc Tukey tests failed to identify pairwise differences. Pairwise Mann-Whitney $U$ tests (with sequential Bonferroni correction, Rice 1989, Appendix Table B.10) showed scenario 5 significantly differed from scenarios $1-4$ only $(p<0.05$; Appendix Table B.10) and delivered three-fold lower mean functioning (Fig. 6A). Scenarios 1-4 contained more taxa with the following traits compared to scenario 5; medium and large body sizes (> $30 \mathrm{~mm}$ ), showing free movement, bioturbate by biodiffusion, deposit feeders and deep sediment dwellers (> $50 \mathrm{~mm}$ ). Therefore, a correspondence existed between the trait composition, functional estimates (Table 1, Appendix Fig. B.4A) and the elimination of all temperate taxa from the scenario 5 assemblage, the latter being typified by trait profiles with larger body sizes and deposit feeding modes.

Estimates for C-cycling were significantly higher in scenarios 1-4 than scenario 5 in the winter (ANOVA, $F=2.956, p=0.04$; Mann-Whitney $U$ test, $p<0.05$; Fig. 6B, Appendix Table B.10). Higher C-cycling was provided by taxa with medium and large body sizes (> $30 \mathrm{~mm}$ ), a lack of armour, < 2 years longevity and planktotrophic larvae (Table 1, Appendix Fig. B.4A and Table B.10). In the summer estimates for biogenic habitat provision were higher in scenarios 3 and 4 compared with scenario 5 (ANOVA, F = 4.240, p < 0.001; Appendix B). However, the trait modalities included in the functional estimates (Table 1) represented a small proportion of the total density (and < 10\% of the cumulative SIMPER dissimilarity) between the trait composition of the different scenarios (Appendix Table B.10).

For the constrained data the trait composition of the assemblage representing scenario 5 differed from all of the other scenarios (Appendix Table B.7), and for the three constrained functional estimates (Table 1) only biogenic habitat significantly differed between assemblages. The nature of the differences was consistent with that for the unconstrained estimates (Appendix Table B.6). 
Using new data on mudflat macrofaunal communities together with historic biogeographic datasets poleward biogeographic range expansions were identified for up to eight typically tropical species, representing $14 \%$ of the 50 taxa recorded from mudflats. To date this is the most comprehensive survey of mudflat macrofauna in SE Queensland, with most past work focussing on macrofauna within intertidal seagrass meadows (38\%), mangroves (9\%) and sandflats (16\%) with mudflats forming only $\sim 10 \%$ of the published work within the region. The SE Queensland assemblages were typical for the subtropics (Davie and Phillips, 2010; Dissanayake et al., 2018; Dissanayake et al. 2019; Johnson, 2010) having a mixture of species with tropical and temperate affinities, in the mudflats $50 \%$ of species were temperate and $40 \%$ tropical (ALA, 2018; OBIS, 2018). Similar patterns are observed for rocky shore invertebrates (Endean et al., 1956) and fish (Johnson, 2010) in Moreton Bay reflecting the transition from the Temperate Australasian to Central Indo-Pacific biogeographic realms at $25^{\circ} \mathrm{S}$ (Spalding et al., 2007). However, biogeographic shifts are apparent for fish (Fowler et al., 2017; Sunday et al., 2015), rocky shore (Poloczanska et al., 2011) and mudflat species (the present study) and further climatic warming may cause the biogeographic boundaries to move.

The documented shifts of mudflat macroinvertebrates are consistent with the widely reported movements of marine and terrestrial species towards the poles as a result of anthropogenic warming (Freeman et al., 2018; Poloczanska et al., 2016), and prompted us to ask how will the ecological functioning of marine ecosystems be affected by this restructuring of macrofaunal assemblages? Simulations were used to explore how macrofaunal assemblages formed by past, present and future biogeographic shifts will impact mudflat community structure and functioning. Our results suggest that even quite severe changes in species composition will not fundamentally alter the ecological functioning or the delivery of ecosystem services, initially because species with similar traits will compensate for the species lost. However, as the severity of the perturbation increase a sudden collapse in functioning may occur. This pattern of compensation followed by a catastrophic failure has previously been reported for hypoxia in ancient oceans (Caswell and Frid, 2017), and those experiencing high levels of anthropogenic organic enrichment (Caswell et al., 2018).

\subsection{Biogeographic range expansions of macrofaunal taxa}


Changes in biogeographic ranges have been documented for 54 species in the SW Pacific and more than 360 marine species globally, across most taxonomic groups and ocean regions, at a mean rate of $45972 \mathrm{~km} \mathrm{decade}^{-1}$ at the leading edge (Poloczanska et al., 2013; Poloczanska et al., 2016). For most of 460 these range shifts increases in average global surface air and seawater temperatures since the start

Species traits that may facilitate biogeographic range shifts include large existing geographic ranges (and so thermal tolerances) and wide dispersal abilities, these taxa are more likely to successfully colonise new habitats (Cheung et al., 2009; Cowen and Sponaugle, 2009). Sunday et al. (2015) showed that this was the case for pelagic fish in SE Australia and that many of the fish species were omnivorous meaning they could exploit a greater range of resources. However, to date predictions based on these traits have had limited power to explain the pattern of marine species range shifts (Angert et al., 2011; Pinsky et al., 2013; Przeslawski et al., 2012). The tropical range shifters documented in the present study did not differ from any of the non-shifting taxa with respect to these traits, similar results have been found for range shifters in the temperate Atlantic benthos (Hale et al., 2017). The faster rates of expansion for benthic invertebrates reported in the present study might be facilitated by oceanographic features such as the strong (up to $1.3 \mathrm{~ms}^{-1}$ ) southward 
flowing East Australia Current which promotes larval and juvenile dispersal (Booth et al., 2007), which has strengthened with climate change and now penetrates further south than prior to the

Species distributional responses to increasing SST are mixed, in addition to shifts at the leading edge of species biogeographic ranges some taxa lag or do not respond, and equatorward shifts such as those documented herein have been observed in response to complex regional phenomena (i.e., where seawater temperatures may vary locally or geographical barriers exist; Burrows et al., 2014; Pinsky et al., 2013) or due to differences in species biology or ecology (Poloczanska et al., 2013). For instance, in subtidal benthic communities along the Atlantic coast of USA between 1990 and 2010 $60 \%$ of species shifted north (poleward) by on average $181 \mathrm{~km}$ and $23 \%$ shifted $\sim 65 \mathrm{~km}$ southward (equatorward) (Hale et al., 2017). Of the two species of temperate taxa that seem to have expanded their geographic ranges towards the tropics in the present study, M. australiensis moved the furthest (368 km in 5 years). This rate is at the upper end of estimates for natural range expansions, and could indicate an introduction, for example on ship hulls or in ballast water (e.g. Ricciardi, 2016). None of the range shifting taxa were documented in the global non-native invasive species database (Invasive Species Specialist Group ISSG, 2015), however species introductions have been observed for Laternula anatina (Pagad et al., 2018) and the congenerics Clorida albolitura (Galil et al., 2009), Haminoea japonica (Hanson et al., 2013) and M. pentadentata (Nygren, 2004). Some of the equatorward shifts may simply result from the higher sampling intensity used in this study and so may represent new records and not biogeographic range shifts (e.g. McPhee, 2017). However, regional environmental variations may also contribute, for instance, within Australia the fastest warming ( $30 \%$ faster than in Queensland) is occurring in a 'hotspot' on the south western and south eastern coasts (CSIRO and Bureau of Meteorology, 2015; Hobday and Pecl, 2014).

Reporting range shifts can be fraught with difficulties (Przeslawski et al., 2012), but our range shift data conform to the rigorous criteria employed by other studies (Parmesan and Yohe, 2003; Przeslawski et al., 2012; Sorte et al., 2010) for identifying range shifts, e.g. the data are based on species occurrences, not abundances, and are collected from assemblages not individual species. Further, all species were found at $>4$ mudflats and were abundant in the majority of the mudflats 
sampled. However, it is not possible to determine when the range shifts occurred nor when they achieved their current southerly limits, except to say that they shifted sometime between their most recent record in ALA or OBIS and our 2016-2017 sampling. Thus, the estimated rates of range shifts 527 are maximums and assume movement spanned the entire time period between the two records. 528 Given the paucity of studies in SE Queensland mudflats, some of these range expansions could 529 simply result from new records due to greater sampling effort. Therefore, the findings of this study 530 need to be further validated by conducting more extensive benthic sampling programs in this and other 'biogeographic boundary zones'.

Whilst the species within assemblages have differing identities, they often share traits (e.g. morphology, life history and behavioural characteristics; Bremner et al., 2006; Peres and Dolman, 2000) usually resulting in less variation in traits than taxa between assemblages (Bremner, 2008; Törnroos et al., 2013). For instance, the trait composition of subtidal benthos around the UK does not differ regionally between the southern North Sea and eastern English Channel unlike the taxonomic composition (Bremner et al., 2003). At the global scale this may also be true: clear latitudinal differences exist in the taxa that dominate marine systems e.g. the proportions of decapods and bivalves are higher in tropical mudflats (Boschi, 2000; Crame, 2000; Dissanayake et al., 2018). Therefore, it is likely that shifts in functioning will occur that are associated with the differing biology of these taxonomic groups when temperate species are replaced by tropical ones. Similar to the previously documented regional (Bremner et al., 2003; Hemingson and Bellwood, 2018; Toussaint et al., 2016) and global trends (e.g. Dissanayake et al., 2018; Safi et al., 2011), spatial differences in the taxa present but not their traits suggest conservation of the macrofaunal contribution to mudflat functioning within SE Queensland. The assemblages seemed to perform similar functional roles at the northernmost and southernmost (Fig. 1) ends of the biogeographic gradient. Therefore, turnover of species in these assemblages will not necessarily result in changes in trait composition or functioning.

Up to eight tropical macroinvertebrate species were identified that have moved on average $145 \mathrm{~km}$ southwards in the last 60 years, and it is likely that these changes were driven by increasing SST on the SE Queensland coast. Mean SST in Queensland is predicted to increase $0.6-0.8^{\circ} \mathrm{C}$ by 2030 and $0.8-$ $2.9^{\circ} \mathrm{C}$ by 2090 (IPCC scenarios RCP2.6, RCP4.5 and RCP8.5) above the 1986-2005 baseline (CSIRO and Bureau of Meteorology, 2015; IPCC, 2014). Given future forecasts, it is highly likely that further shifts 
will occur leading to a restructuring of macrofaunal assemblages. Such changes may include alterations to the biological traits and ecological functioning of macrofaunal assemblages. In the present study biogeographic range shifts were simulated to produce five novel species compositions

560 for mudflats. By altering species composition, changes in the associated traits of macrofauna that mediate a range of benthic functions were also simulated. Specific biological trait modalities were mapped onto functions and it was assumed that all modalities contributed equally to functioning. This assumption was tested using an alternative model, and the functional estimates were found to be insensitive to the differential trait weighting (Frid and Caswell, 2016) and so the, unweighted, results presented here are conservative in describing functional change. This is consistent with other studies using this approach (Clare et al., 2015; Frid and Caswell, 2016). However, note these estimates

Experimental studies are of limited utility for anticipating complex changes in ecosystem dynamics, therefore to predict ecosystem responses models are needed that explore hypothetical scenarios of species movements. In the present study, models of changing assemblage composition were based on three main assumptions. Firstly, species sharing physiological characteristics were assumed to move together rather than individually. Uncertainty regarding the species-specific relative rates of movement made it difficult to determine exactly where and when taxa will arrive. Secondly, species are assumed to function similarly within the new and existing assemblages, however this is unlikely to always be the case (Alexander et al., 2015). For instance, the feeding (Cesar and Frid, 2012) or burrowing behaviour (Olafsson, 1986) of taxa may vary between sediments with differing properties, and so the expression of their traits and the delivery of functioning may also differ. Thirdly, species relative abundances were assumed to be either: equivalent to the areas in which they presently reside (unconstrained total abundance; Table 2, Fig. 5); or, the total carrying capacity of the system was constrained whilst the relative proportions of taxa remained the same. The functioning estimates derived from these constrained and unconstrained formulations of the model followed similar trends. This suggests that while the abundance effect was clearly present in setting the quanta of the function predicted by the model, the pattern of functional change was robust under the different model formulations. This supports interpretations of a period of consistent functioning, 
The transition from a 'pre-invasion' to the present-day scenario considers the arrival of up to eight taxa that have shifted southwards by 6-447 km over 23-70 years. These shifts are commensurate with $a \sim 1{ }^{\circ} \mathrm{C}$ increase in air and seawater surface temperatures (above the 1961-1990 average; CSIRO and Bureau of Meteorology, 2015, 2018; IPCC, 2014). In the 'further invasion' scenario tropical taxa moved $84 \mathrm{~km}$ south from Nudgee Beach to the mudflats between Redland Bay and Tallebudgera at on average $49 \mathrm{~km}$ decade ${ }^{-1}$. If the rate of SST increase remained constant these taxa would reach Tallebudgera by $\sim 2036$. Our comparison of hypothetical scenarios shows that biological traits, and therefore also functioning, were initially conserved followed by a potential threshold when 10-50\% of macrofaunal species were lost. This is seen in the shift between 'further invasion by tropical taxa sensitive to SST' (4 taxa, scenario 4) and subsequent loss of the temperate component of the assemblage (24 taxa, scenario 5). To date most marine species shifts have produced changes in trophic dynamics e.g. predator-prey dynamics or grazing patterns (e.g. Fowler et al., 2017; Ling, 2008; Vergés et al., 2016), but there are comparatively few identifying changes in nutrient or Ccycling within marine (but see Pessarrodona et al., 2019) or terrestrial systems (Collins et al., 2016; Pureswaran et al., 2015; Zhao et al., 2019). In the present study, estimates for nutrient cycling, Ccycling and biogenic habitat provision were three-fold lower after the loss of all temperate taxa compared with any other scenario (including the current scenario). Although the differences in emergent biogenic habitat provision were a small proportion of total functioning.

An increasing number of marine species are exhibiting changes in their biogeographic distributions, and these shifts are predicted to continue leading to elevated local extinctions in tropical and subpolar regions (Cheung et al. 2009). Thus, novel species compositions will continue to form, however, considerable uncertainty remains regarding which species move and how the recipient communities will respond to the new arrivals. Experimental simulations have shown that differences in species interactions based on their traits can be more important predictors of ecosystem responses to 'invasion' than their physiological limits (Alexander et al., 2015). Forecasts of the possible impacts therefore could be improved by greater understanding of the functional dynamics of marine ecosystems. In this study it was only under the most extreme scenarios of species shifts that functioning differed from the southern baseline assemblage. These changes were primarily driven by the loss of the temperate species, for which the invading tropical species, which had a different mix of traits, were unable to fully compensate. Arrival of novel species can also strongly undermine the performance of stressed communities through competition and predation. Functional dissimilarity between the incoming 'novel competitors' and 'resident competitors' has a greater impact at the trailing compared with the leading edges of species ranges (Alexander et al., 2015). Thus, the 
impacts of changes in trait composition presented in this study are likely to be more moderate than in mudflats at the trailing edges. The vulnerability of ecosystem service delivery in coastal areas to climate-induced species redistribution needs to be considered within climate change resilience and mitigation planning. This study shows that these impacts could occur suddenly, associated with thresholds making collapses challenging to predict. Managers, fisheries and aquaculture sectors and others concerned with healthy functioning ecosystems in coastal systems need to be aware of these risks.

648

649 650

Acknowledgements

We gratefully thank the Quandamooka people the traditional custodians of the land and sea country where this work took place and respectfully acknowledge their elder's past, present and emerging. The work presented in the manuscript was funded by scholarships from the School of Environment and Science, Griffith University and the Environmental Futures Research Institute, Queensland. Thanks to Mike Elliott for editorial support, and two anonymous reviewers who helped us to improve the manuscript. We are grateful to Christopher Glasby (Museum and Art Gallery of the Northern Territory), Robin Wilson and Genefor Walker-Smith (Museum Victoria), and John Healy (Queensland Museum) for sharing their taxonomic expertise. Thanks to Dale Bryan-Brown, Nadeeka Rathnayake, Upul Wijeratne, Zachary Paterson, Ben Mackenzie, Amanda Bowler, Sarah Engelhard, Majid Bakhtiyari and Shafagh Kamal among others for assistance with field data collection. Discussions with Pat Hutchings, Ashely Rowden and Rod Connolly helped to develop the work. We would like to thank the Department of National Parks, Sport and Racing, Queensland Government for assistance with permits for selected sites within the Moreton Bay Marine Park, and Craig Wilson at the Port of Brisbane Pty Ltd. for facilitating access to field sites.

\section{References}

ALA, 2018. Atlas of Living Australia, 16 November 2018 ed. Altas of Living Australia, Canberra, Australia. https://www.ala.org.au (accessed 17 th April 2019).

Alexander, J.M., Diez, J.M., Levine, J.M., 2015. Novel competitors shape species' responses to climate change. Nature 525, 515-518. DOI: 10.1038/nature14952

Angert, A.L., Crozier, L.G., Rissler, L.J., Gilman, S.E., Tewksbury, J.J., Chunco, A.J., 2011. Do species' traits predict recent shifts at expanding range edges? Ecology Letters 14, 677-689. DOI: 10.1111/j.1461-0248.2011.01620.x 
Barbier, E.B., Hacker, S.D., Kennedy, C., Koch, E.W., Stier, A.C., Silliman, B.R., 2011. The value of estuarine and coastal ecosystem services. Ecological Monographs: 81, 169-193. DOI: 10.1890/10-1510.1

Barnes, R.S.K., Hamylton, S., 2016. On the very edge: faunal and functional responses to the interface between benthic seagrass and unvegetated sand assemblages. Marine Ecology Progress Series 553, 33-48. DOI: 10.3354/meps11800

Bateman, I.J., Harwood, A.R., Mace, G.M., Watson, R.T., Abson, D.J., Andrews, B., Binner, A., Crowe, A., Day, B.H., Dugdale, S., 2013. Bringing ecosystem services into economic decision-making: land use in the United Kingdom. Science 341, 45-50. DOI: 10.1126/science.1234379

Biles, C.L., Solan, M., Isaksson, I., Paterson, D.M., Emes, C., Raffaelli, D.G., 2003. Flow modifies the effect of biodiversity on ecosystem functioning: an in situ study of estuarine sediments. Journal of Experimental Marine Biology and Ecology: 285, 165-177. DOI: 10.1016/S00220981(02)00525-7Blackburn, T.H., 1986. Nitrogen cycle in marine sediments. Ophelia 26, 6576. DOI: 10.1080/00785326.1986.10421979

Bolam, S.G., Fernandes, T.F., Huxham, M., 2002. Diversity, biomass, and ecosystem processes in the marine benthos. Ecological Monographs 72, 599-615. DOI: 10.1890/00129615(2002)072[0599:DBAEPI]2.0.CO;2

Bonada, N., DolÉDec, S., Statzner, B., 2007. Taxonomic and biological trait differences of stream macroinvertebrate communities between mediterranean and temperate regions: implications for future climatic scenarios. Global Change Biology 13, 1658-1671. DOI: 10.1111/j.1365-2486.2007.01375.x

Bonebrake, T.C., Brown, C.J., Bell, J.D., Blanchard, J.L., Chauvenet, A., Champion, C., Chen, I.-C., Clark, T.D., Colwell, R.K., Danielsen, F., Dell, A.I., Donelson, J.M., Evengård, B., Ferrier, S., Frusher, S., Garcia, R.A., Griffis, R.B., Hobday, A.J., Jarzyna, M.A., Lee, E., Lenoir, J., Linnetved, H., Martin, V.Y., McCormack, P.C., McDonald, J., McDonald-Madden, E., Mitchell, N., Mustonen, T., Pandolfi, J.M., Pettorelli, N., Possingham, H., Pulsifer, P., Reynolds, M., Scheffers, B.R., Sorte, C.J.B., Strugnell, J.M., Tuanmu, M.-N., Twiname, S., Vergés, A., Villanueva, C., Wapstra, E., Wernberg, T., Pecl, G.T., 2018. Managing consequences of climate-driven species redistribution requires integration of ecology, conservation and social science. Biological Reviews 93, 284-305. DOI: 10.1111/brv.12344

Booth, D.J., Figueira, W.F., Gregson, M.A., Brown, L., Beretta, G., 2007. Occurrence of tropical fishes in temperate southeastern Australia: role of the East Australian Current. Estuarine, Coastal and Shelf Science 72, 102-114. DOI: 10.1016/j.ecss.2006.10.003 
Boschi, E.E., 2000. Biodiversity of marine decapod brachyurans of the Americas. Journal of Crustacean Biology 20, 337-342. DOI: 10.1163/1937240X-90000036

Boulding, E.G., 1984. Crab-resistant features of shells of burrowing bivalves: decreasing vulnerability by increasing handling time. Journal of Experimental Marine Biology and Ecology: 76, 201223. DOI: $10.1016 / 0022-0981(84) 90189-8$

Bremner, J., 2008. Species' traits and ecological functioning in marine conservation and management. Journal of Experimental Marine Biology and Ecology 366, 37-47. DOI: 10.1016/j.jembe.2008.07.007

Bremner, J., Rogers, S.I., Frid, C.L.J., 2003. Assessing functional diversity in marine benthic ecosystems: a comparison of approaches. Marine Ecology Progress Series 254, 11-25. DOI: 10.3354/meps254011

Bremner, J., Rogers, S.I., Frid, C.L.J., 2006. Methods for describing ecological functioning of marine benthic assemblages using biological traits analysis (BTA). Ecological Indicators 6, 609-622. DOI: $10.1016 /$ j.ecolind.2005.08.026

Buhl-Mortensen, L., Vanreusel, A., Gooday, A.J., Levin, L.A., Priede, I.G., Buhl-Mortensen, P., Gheerardyn, H., King, N.J., Raes, M., 2010. Biological structures as a source of habitat heterogeneity and biodiversity on the deep ocean margins. Marine Ecology 31, 21-50. DOI: 10.1111/j.1439-0485.2010.00359.x

Burrows, M.T., Schoeman, D.S., Richardson, A.J., Molinos, J.G., Hoffmann, A., Buckley, L.B., Moore, P.J., Brown, C.J., Bruno, J.F., Duarte, C.M., 2014. Geographical limits to species-range shifts are suggested by climate velocity. Nature 507, 492-495. DOI: 10.1038/nature12976

Caswell, B.A., Frid, C.L., 2017. Marine ecosystem resilience during extreme deoxygenation: the Early Jurassic oceanic anoxic event. Oecologia 183, 275-290. DOI: 10.1007/s00442-016-3747-6

Caswell, B.A., Paine, M., Frid, C.L.J., 2018. Seafloor ecological functioning over two decades of organic enrichment. Marine Pollution Bulletin 136, 212-229. DOI: 10.1016/j.marpolbul.2018.08.041

Cesar, C.P., Frid, C.L.J., 2012. Benthic disturbance affects intertidal food web dynamics: implications for investigations of ecosystem functioning. Marine Ecology Progress Series 466, 35-41. DOI: 10.3354/meps09938

Champion, C., Hobday, A.J., Tracey, S.R., Pecl, G.T., 2018. Rapid shifts in distribution and high-latitude persistence of oceanographic habitat revealed using citizen science data from a climate change hotspot. Global Change Biology 24, 5440-5453. DOI: 10.1111/gcb.14398

Chen, I.-C., Hill, J.K., Ohlemüller, R., Roy, D.B., Thomas, C.D., 2011. Rapid range shifts of species associated with high levels of climate warming. Science 333, 1024-1026. DOI: 10.1126/science.1206432

Cheung, W.W.L., Lam, V.W.Y., Sarmiento, J.L., Kearney, K., Watson, R., Pauly, D., 2009. Projecting global marine biodiversity impacts under climate change scenarios. Fish and Fisheries 10 , 235-251. DOI: 10.1111/j.1467-2979.2008.00315.x 
Chevene, F., Doléadec, S., Chessel, D., 1994. A fuzzy coding approach for the analysis of long-term ecological data. Freshwater Biology 31, 295-309. DOI: 10.1111/j.1365-2427.1994.tb01742.x

Clare, D.S., Robinson, L.A., Frid, C.L.J., 2015. Community variability and ecological functioning: 40 years of change in the North Sea benthos. Marine Environmental Research 107, 24-34. DOI: 10.1016/j.marenvres.2015.03.012

Collins, C.G., Carey, C.J., Aronson, E.L., Kopp, C.W., Diez, J.M., 2016. Direct and indirect effects of native range expansion on soil microbial community structure and function. Journal of Ecology 104, 1271-1283. DOI: 10.1111/1365-2745.12616.

Costanza, R., de Groot, R., Sutton, P., van der Ploeg, S., Anderson, S.J., Kubiszewski, I., Farber, S., Turner, R.K., 2014. Changes in the global value of ecosystem services. Global Environmental Change 26, 152-158. DOI: 10.1016/j.gloenvcha.2014.04.002

Cowen, R.K., Sponaugle, S., 2009. Larval dispersal and marine population connectivity. Annual Review of Marine Science 1, 443-466. DOI: 10.1146/annurev.marine.010908.163757

- Crame, A.J., 2000. Evolution of taxonomic diversity gradients in the marine realm: evidence from the composition of recent bivalve faunas. Paleobiology 26, 188-214. DOI: 10.1666/0094-8373(2000)026<0188:EOTDGI>2.0.CO;2

Crowe, T.P., Frid, C.L.J., 2015. Marine Ecosystems: Human Impacts on Biodiversity, Functioning and Services. Cambridge University Press, United Kingdom, pp. 406.

CSIRO and Bureau of Meteorology, 2015. Climate Change in Australia Information for Australia's Natural Resource Management Regions. Technical Report. CSIRO and Bureau of Meteorology, Australia.

CSIRO and Bureau of Meteorology, 2018. State of the Climate 2018. Technical report. Australian Government, Canberra.

Culhane, F.E., Frid, C.L.J., Royo Gelabert, E., White, L., Robinson, L.A., 2018. Linking marine ecosystems with the services they supply: what are the relevant service providing units? Ecological Applications 28, 1740-1751. DOI: 10.1002/eap.1779

Dambacher, J.M., Hosack, G.R., Rochester, W.A., 2012. Ecological Indicators for the Exclusive Economic Zone of Australia's South East Marine Region. A report prepared for the Australian Government Department of Sustainability, Environment, Water, Population and Communities. CSIRO Wealth from Oceans Flagship, Hobart, p. 125.

Davie, P.J.F., Phillips, J.A., 2010. Proceedings of the 13th International Marine Biological Workshop, The Marine Fauna and Flora of Moreton Bay, Queensland, Dunwich, Queensland, Australia, 7-25 February, 2005. Memoirs of the Queensland Museum: 54.

Department of Environment and Science, 2019. Moreton Bay Ramsar internationally important wetland. Technical report. Queensland Government, Queensland.

Deutsch, C., Ferrel, A., Seibel, B., Pörtner, H.-O., Huey, R.B., 2015. Climate change tightens a metabolic constraint on marine habitats. Science 348, 1132. DOI: 10.1126/science.aaa1605 
Dissanayake, N.G., Frid, C.L.J., Drylie, T.P., Caswell, B.A., 2018. Ecological functioning of mudflats: global analysis reveals both regional differences and widespread conservation of functioning. Marine Ecology Progress Series 604, 1-20. DOI: 10.3354/meps12728

Dissanayake, N.G., Frid, C.L.J., Caswell, B.A., 2019. Biodiversity, trait compositon and ecological functioning: impacts of urbanisation on subtropical mudflats. Marine and Freshwater Research 70, 1-19. DOI: 10.1071/MF19242

Dittmann, S., 1996. Effects of macrobenthic burrows on infaunal communities in tropical tidal flats. Marine Ecology Progress Series 134, 119-130. DOI: 10.3354/meps134119.

Dittmann, S., 2002. Benthic fauna in tropical tidal flats of Hinchinbrook Channel, NE Australia: diversity, abundance and their spatial and temporal variation. Wetlands Ecology and Management 10, 323-333. DOI: 10.1023/A:1020350413374

Eertman, R.H.M., Hailstone, T.S., 1988. Zonation of intertidal epifauna on jetty piles in Moreton Bay, Queensland. Journal of the Malacological Society of Australia 9, 11-18. DOI: 10.1080/00852988.1988.10673995

Endean, R., Kenny, R., Stephenson, W., 1956. The ecology and distribution of intertidal organisms on the rocky shores of the Queensland mainland. Marine and Freshwater Research 7, 88-146. DOI: 10.1071/MF9560088

ETI Bioinformatics, 2018. Marine Species Indentification Portal. KeyToNature programme. www.species-identification.org (accessed 13 ${ }^{\text {th }}$ April 2019).

Faulwetter, S., Markantonatou, V., Pavloudi, C., Papageorgiou, N., Keklikoglou, K., Chatzinikolaou, E., Pafilis, E., Chatzigeorgiou, G., Vasileiadou, K., Dailianis, T., 2014. Polytraits: A database on biological traits of marine polychaetes. Biodiversity Data 2.

Fowler, A.M., Parkinson, K., Booth, D.J., 2017. New poleward observations of 30 tropical reef fishes in temperate southeastern Australia. Marine Biodiversity 48, 2249-2254. DOI: 10.1007/s12526-017-0748-6

Freeman, B.G., Lee-Yaw, J.A., Sunday, J.M., Hargreaves, A.L., 2018. Expanding, shifting and shrinking: The impact of global warming on species' elevational distributions. Global Ecology and Biogeography 27, 1268-1276. DOI: 10.1111/geb.12774

Frid, C.L.J., Caswell, B.A., 2016. Does ecological redundancy maintain functioning of marine benthos on centennial to millennial time scales? Marine Ecology 37, 392-410. DOI: 10.1111/maec.12297

Galil, B.S., Yokes, M.B., Goren, M., Diamant, A., 2009. First record of the Indo-West Pacific mantis shrimp, Clorida albolitura Ahyong \& Naiyanetr, 2000 (Stomatopoda, Squillidae) in Turkey. Aquatic Invasions 4, 701-702. DOI: 10.3391/ai.2009.4.4.19 
Greve, W., Reiners, F., Nast, J., Hoffmann, S., 2004. Helgoland Roads meso-and macrozooplankton time-series 1974 to 2004: lessons from 30 years of single spot, high frequency sampling at the only off-shore island of the North Sea. Helgoland Marine Research: 58, 274-288. DOI: 10.1007/s10152-004-0191-5.

Hale, S.S., Buffum, H.W., Kiddon, J.A., Hughes, M.M., 2017. Subtidal benthic invertebrates shifting northward along the US Atlantic Coast. Estuaries and Coasts 40, 1744-1756. DOI: 10.1007/s12237-017-0236-z.

Hanson, D., Cooke, S., Hirano, Y., Malaquias, M.A., Crocetta, F., Valdés, Á., 2013. Slipping through the cracks: the taxonomic impediment conceals the origin and dispersal of Haminoea japonica, an invasive species with impacts to human health. PloS One 8, e77457. DOI: 10.1371/journal.pone.0077457.

Heinen, E.A., McManus, J., 2004. Carbon and Nutrient Cycling at the Sediment-water Boundary in Western Lake Superior. Journal of Great Lakes Research 30, 113-132. DOI: 10.1016/S03801330(04)70381-0

Hemingson, C.R., Bellwood, D.R., 2018. Biogeographic patterns in major marine realms: function not taxonomy unites fish assemblages in reef, seagrass and mangrove systems. Ecography 41, 174-182. DOI: 10.1111/ecog.03010

Himes-Cornell, A., Grose, S.O., Pendleton, L., 2018. Mangrove Ecosystem Service Values and Methodological Approaches to Valuation: Where Do We Stand? Frontiers in Marine Science 5, 376. DOI: 10.3389/fmars.2018.00376.

Hobday, A.J., 2010. Ensemble analysis of the future distribution of large pelagic fishes off Australia. Progress in Oceanography 86, 291-301. DOI: 10.1016/j.pocean.2010.04.023.

Hobday, A.J., Pecl, G.T., 2014. Identification of global marine hotspots: sentinels for change and vanguards for adaptation action. Reviews in Fish Biology and Fisheries 24, 415-425. DOI: 10.1007/s11160-013-9326-6.

Hutchings, P., Kupriyanova, E., 2018. Cosmopolitan polychaetes-fact or fiction? Personal and historical perspectives. Invertebrate Systematics 32, 1-9. DOI: 10.1071/IS17035.

Hyndes, G.A., Nagelkerken, I., McLeod, R.J., Connolly, R.M., Lavery, P.S., Vanderklift, M.A., 2014. Mechanisms and ecological role of carbon transfer within coastal seascapes. Biological Reviews 89, 232-254. DOI: 10.1111/brv.12055

Inglis, G.J., Kross, J.E., 2000. Evidence for Systemic Changes in the Benthic Fauna of Tropical Estuaries as a Result of Urbanization. Marine Pollution Bulletin 41, 367-376. DOI: 10.1016/S0025326X(00)00093-X 
Invasive Species Specialist Group (ISSG), 2015. The Global Invasive Species Database. Invasive Species Specialist Group of the Species Survival Commission (SSC) of the International Union for Conservation of Nature (IUCN). http://www.issg.org/database (accessed 1st July 2019).

Intergovernmental Panel on Climate Change, 2014. Climate Change 2014: Synthesis Report. Contribution of Working Groups I, II and III to the Fifth Assessment Report of the Intergovernmental Panel on Climate Change. IPCC, New York.

Johnson, J.W., 2010. Fishes of the Moreton Bay Marine Park and adjacent continental shelf waters, Queensland, Australia. Memoirs of the Queensland Museum - Nature 54, 299-353.

Katsanevakis, S., Wallentinus, I., Zenetos, A., Leppäkoski, E., Çinar, M.E., Oztürk, B., Grabowski, M., Golani, D., Cardoso, A.C., 2014. Impacts of invasive alien marine species on ecosystem services and biodiversity: a pan-European review. Aquatic Invasions 9, 39-423. DOI: 10.3391/ai.2014.9.4.01

Kortsch, S., Primicerio, R., Fossheim, M., Dolgov, A.V., Aschan, M., 2015. Climate change alters the structure of arctic marine food webs due to poleward shifts of boreal generalists. Proceedings of the Royal Society B: Biological Sciences 282, 20151546. DOI: 10.1098/rspb.2015.1546

Kristensen, E., Delefosse, M., Quintana, C.O., Flindt, M.R., Valdemarsen, T., 2014. Influence of benthic macrofauna community shifts on ecosystem functioning in shallow estuaries. Frontiers in Marine Science 1, 41. DOI: 10.3389/fmars.2014.00041

Kristensen, E., Penha-Lopes, G., Delefosse, M., Valdemarsen, T., Quintana, C.O., Banta, G.T., 2012. What is bioturbation? The need for a precise definition for fauna in aquatic sciences. Marine Ecology Progress Series 446, 285-302. DOI: 10.3354/meps09506

Landschoff, J., Lackschewitz, D., Kesy, K., Reise, K., 2013. Globalization pressure and habitat change: Pacific rocky shore crabs invade armored shorelines in the Atlantic Wadden Sea. Aquatic Invasions 8, 77-87. DOI: 10.3391/ai.2013.8.1.09

Ling, S.D., 2008. Range expansion of a habitat-modifying species leads to loss of taxonomic diversity: a new and impoverished reef state. Oecologia 156, 883-894. DOI: 10.1007/s00442-0081043-9

Macdonald, T.A., Burd, B.J., Macdonald, V.I., Van Roodselaar, A., 2010. Taxonomic and feeding guild classification for the marine benthic macroinvertebrates of the Strait of Georgia, British Columbia. Fisheries and Oceans Canada Pêches et Océans Canada, 69 pp.

MarLIN, 2006. BIOTIC - Biological Traits Information Catalogue. Marine Biological Association of the United Kingdom, Plymouth. https://www.marlin.ac.uk (accessed 17th April 2019). 
Mascaró, M., Seed, R., 2001. Choice of prey size and species in Carcinus maenas (L.) feeding on four bivalves of contrasting shell morphology. Hydrobiologia 449, 159-170. DOI: 10.1023/A:1017569809818

McPhee, D., 2017. Environmental History and Ecology of Moreton Bay. CSIRO Publishing, Australia, 224 pp.

Mermillod-Blondin, F., Rosenberg, R., FranÃfÂßois-Carcaillet, F., Norling, K., Mauclaire, L., 2004. Influence of bioturbation by three benthic infaunal species on microbial communities and biogeochemical processes in marine sediment. Aquatic Microbial Ecology 36, 271-284. DOI: 10.3354/ame036271

Nagelkerken, I., Russell, B.D., Gillanders, B.M., Connell, S.D., 2016. Ocean acidification alters fish populations indirectly through habitat modification. Nature Climate Change 6, 89-93. DOI: 10.1038/nclimate2757

Narayan, Y.R., Pandolfi, J.M., 2010. Benthic foraminiferal assemblages from Moreton Bay, South-East Queensland, Australia: Applications in monitoring water and substrate quality in subtropical estuarine environments. Marine Pollution Bulletin 60, 2062-2078. DOI: 10.1016/j.marpolbul.2010.07.012

Norkko, A., Villnäs, A., Norkko, J., Valanko, S., Pilditch, C., 2013. Size matters: implications of the loss of large individuals for ecosystem function. Scientific Reports: 3, 26-46. DOI: 10.1038/srep02646

Nygren, A., 2004. Revision of Autolytinae (Syllidae: Polychaeta). Zootaxa 680, 1-314. DOI: 10.11646/zootaxa.680.1.1

OBIS, 2018. Ocean Biogeographic Information System. International Oceanographic Data and Information Programme. Intergovernmental Oceanographic Commission of UNESCO. www.iobis.org (accessed $13^{\text {th }}$ April 2018).

Olafsson, E.B., 1986. Density Dependence in Suspension-Feeding and Deposit-Feeding Populations of the Bivalve Macoma balthica: A Field Experiment. Journal of Animal Ecology 55, 517-526. DOI: $10.2307 / 4735$.

Pagad, S., Genovesi, P., Carnevali, L., Schigel, D., McGeoch, M.A., 2018. Introducing the Global Register of Introduced and Invasive Species. Scientific Data 5, 1-21. DOI: 10.1038/sdata.2017.202.

Parmesan, C., Yohe, G., 2003. A globally coherent fingerprint of climate change impacts across natural systems. Nature 421, 37-42. DOI: doi.org/10.1038/nature01286 
Pecl, G.T., Araújo, M.B., Bell, J.D., Blanchard, J., Bonebrake, T.C., Chen, I.-C., Clark, T.D., Colwell, R.K., Danielsen, F., Evengård, B., 2017. Biodiversity redistribution under climate change: Impacts on ecosystems and human well-being. Science 355, eaai9214. DOI: 10.1126/science.aai9214

Pereira, H.M., Leadley, P.W., Proença, V., Alkemade, R., Scharlemann, J.P.W., Fernandez-Manjarrés, J.F., Araújo, M.B., Balvanera, P., Biggs, R., Cheung, W.W.L., 2010. Scenarios for global biodiversity in the 21st century. Science 330, 1496-1501. DOI: 10.1126/science.1196624

Peres, C.A., Dolman, P.M., 2000. Density compensation in neotropical primate communities: evidence from 56 hunted and nonhunted Amazonian forests of varying productivity. Oecologia 122, 175-189. DOI: 10.1007/PL00008845.

Pessarrodona, A., Foggo, A., Smale, D.A., 2019. Can ecosystem functioning be maintained despite climate-driven shifts in species composition? Insights from novel marine forests. Journal of Ecology 107, 91-104. DOI: 10.1111/1365-2745.13053

Piepenburg, D., Blackburn, T H., Von Dorrien, C.F., Gutt, J.,, Hall, P.O.J., Hulth, S., Kendall, M.A., Opalinski, K.W., Rachor,, E., S., M.K., 1995. Partitioning of benthic community respiration in the Arctic (northwestern Barents Sea). Marine Ecology Progress Series 118, 199-213. DOI: 10.3354/meps118199

Pinsky, M.L., Worm, B., Fogarty, M.J., Sarmiento, J.L., Levin, S.A., 2013. Marine taxa track local climate velocities. Science 341, 1239-1242. DOI: 10.1126/science.1239352

Poiner, I., 1977. Microvariation in the fauna of a sublittoral sand bank, Moreton Bay, Queensland. Australian Journal of Ecology 2, 297-308. DOI: 10.1111/j.1442-9993.1977.tb01146.x

Poloczanska, E.S., Brown, C.J., Sydeman, W.J., Kiessling, W., Schoeman, D.S., Moore, P.J., Brander, K., Bruno, J.F., Buckley, L.B., Burrows, M.T., 2013. Global imprint of climate change on marine life. Nature Climate Change 3, 919-925. DOI: 10.1038/nclimate1958

Poloczanska, E.S., Burrows, M.T., Brown, C.J., García Molinos, J., Halpern, B.S., Hoegh-Guldberg, O., Kappel, C.V., Moore, P.J., Richardson, A.J., Schoeman, D.S., 2016. Responses of marine organisms to climate change across oceans. Frontiers in Marine Science 3, 1-21. DOI: $10.3389 /$ fmars.2016.00062

Poloczanska, E.S., Smith, S., Fauconnet, L., Healy, J., Tibbetts, I.R., Burrows, M.T., Richardson, A.J., 2011. Little change in the distribution of rocky shore faunal communities on the Australian east coast after 50 years of rapid warming. Journal of Experimental Marine Biology and Ecology 400, 145-154. DOI: 10.1016/j.jembe.2011.02.018

Przeslawski, R., Falkner, I., Ashcroft, M.B., Hutchings, P., 2012. Using rigorous selection criteria to investigate marine range shifts. Estuarine, Coastal and Shelf Science 113, 205-212. DOI: 10.1016/j.ecss.2012.08.005 
Pureswaran, D.S., De Grandpré, L., Paré, D., Taylor, A., Barrette, M., Morin, H., Régnière, J., Kneeshaw, D.D., 2015. Climate-induced changes in host tree-insect phenology may drive ecological state-shift in boreal forests. Ecology 96, 1480-1491. DOI: 10.1890/13-2366.1

Queirós, A.M., Birchenough, S.N., Bremner, J., Godbold, J.A., Parker, R.E., Romero-Ramirez, A., Reiss, H., Solan, M., Somerfield, P.J., Colen, C., 2013. A bioturbation classification of European marine infaunal invertebrates. Ecology and Evolution 3, 3958-3985. DOI: 10.1002/ece3.769

Ramos, J.E., Pecl, G.T., 2015. Climate Change. Marine range shifts in SE Australia. Technical report Institute for Marine and Antarctic Studies, University of Tasmania.

Ratnasingham, S., Hebert, P.D.N., 2007. BOLD: The Barcode of Life Data System (http://www. barcodinglife. org). Molecular Ecology Resources 7, 355-364.

Ricciardi, A., 2016. Tracking marine alien species by ship movements. Proceedings of the National Academy of Sciences 113, 5470-5471. DOI: 10.1073/pnas.1605152113

Ridgway, K.R., 2007. Long-term trend and decadal variability of the southward penetration of the East Australian Current. Geophysical Research Letters 34, 1-5. DOI: 10.1029/2007GL030393

Rijnsdorp, A.D., Peck, M.A., Engelhard, G.H., Möllmann, C., Pinnegar, J.K., 2009. Resolving the effect of climate change on fish populations. ICES Journal of Marine Science 66, 1570-1583. DOI: 10.1093/icesjms/fsp056

Safi, K., Cianciaruso, M.V., Loyola, R.D., Brito, D., Armour-Marshall, K., Diniz-Filho, J.A.F., 2011. Understanding global patterns of mammalian functional and phylogenetic diversity. Philosophical Transactions of the Royal Society B: Biological Sciences 366, 2536-2544. DOI: $10.1098 /$ rstb.2011.0024

Scheffer, M., Carpenter, S., Foley, J.A., Folke, C., Walker, B., 2001. Catastrophic shifts in ecosystems. Nature 413, 591596.DOI: doi.org/10.1038/35098000

Sorte, C.J., Williams, S.L., Carlton, J.T., 2010. Marine range shifts and species introductions: comparative spread rates and community impacts. Global Ecology and Biogeography 19, 303-316. DOI: 10.1111/j.1466-8238.2009.00519.x

Spalding, M.D., Fox, H.E., Allen, G.R., Davidson, N., Ferdaña, Z.A., Finlayson, M., Halpern, B.S., Jorge, M.A., Lombana, A., Lourie, S.A., 2007. Marine ecoregions of the world: a bioregionalization of coastal and shelf areas. BioScience 57, 573-583. DOI: 10.1641/B570707

Sunday, J.M., Bates, A.E., Dulvy, N.K., 2012. Thermal tolerance and the global redistribution of animals. Nature Climate Change 2, 686-690. DOI: 10.1038/nclimate1539

Sunday, J.M., Pecl, G.T., Frusher, S., Hobday, A.J., Hill, N., Holbrook, N.J., Edgar, G.J., Stuart-Smith, R., Barrett, N., Wernberg, T., 2015. Species traits and climate velocity explain geographic range shifts in an ocean-warming hotspot. Ecology Letters 18, 944-953. DOI: 10.1111/ele.12474 
Thrush, S.F., Hewitt, J.E., Gibbs, M., Lundquist, C., Norkko, A., 2006. Functional role of large organisms in intertidal communities: community effects and ecosystem function. Ecosystems: 9, 1029-1040. DOI: 10.1007/s10021-005-0068-8

Törnroos, A., Nordström, M.C., Bonsdorff, E., 2013. Coastal Habitats as Surrogates for Taxonomic, Functional and Trophic Structures of Benthic Faunal Communities. PLOS ONE 8, e78910. DOI: 10.1371/journal.pone.0078910

Toussaint, A., Charpin, N., Brosse, S., Villéger, S., 2016. Global functional diversity of freshwater fish is concentrated in the Neotropics while functional vulnerability is widespread. Scientific Reports: 6, 1 Toussaint, A., Charpin, N., Brosse, S., Villéger, S., 2016. Global functional diversity of freshwater fish is concentrated in the Neotropics while functional vulnerability is widespread. Scientific Reports 6, 1-9. DOI: 10.1038/srep22125

Van Oevelen, D., Soetaert, K., Middelburg, J.J., Herman, P.M.J., Moodley, L., Hamels, I., Moens, T., Heip, C.H.R., 2006. Carbon flows through a benthic food web: Integrating biomass, isotope and tracer data. Journal of Marine Research 64, 453-482. DOI: $10.1357 / 002224006778189581$

Vergés, A., Doropoulos, C., Malcolm, H.A., Skye, M., Garcia-Pizá, M., Marzinelli, E.M., Campbell, A.H., Ballesteros, E., Hoey, A.S., Vila-Concejo, A., 2016. Long-term empirical evidence of ocean warming leading to tropicalization of fish communities, increased herbivory, and loss of kelp. Proceedings of the National Academy of Sciences 113, 13791-13796. DOI: 10.1073/pnas.1610725113

Vermeij, G.J., Roopnarine, P.D., 2008. The Coming Arctic Invasion. Science 321, 780-781. DOI: 10.1126/science. 1160852

Wethey, D.S., Woodin, S.A., Hilbish, T.J., Jones, S.J., Lima, F.P., Brannock, P.M., 2011. Response of intertidal populations to climate: effects of extreme events versus long term change. Journal of Experimental Marine Biology and Ecology 400, 132-144. DOI: 10.1016/j.jembe.2011.02.008

WoRMS Editorial Board (2016) World Register of Marine Species (WoRMS). http://www.marinespecies.org at VLIZ (accessed $1^{\text {st }}$ August 2018).

Young, P., Wadley, V., 1979. Distribution of shallow-water epibenthic macrofauna in Moreton Bay, Queensland, Australia. Marine Biology 53, 83-97. DOI: 10.1007/BF00386532

Zeuthen, E., 1953. Oxygen uptake as related to body size in organisms. The Quarterly Review of Biology 28, 1-12. DOI: 10.1086/399308 
999 Zhao, M., Sun, B., Wu, L., Wang, F., Wen, C., Wang, M., Liang, Y., Hale, L., Zhou, J., Yang, Y., 2019. Dissimilar responses of fungal and bacterial communities to soil transplantation simulating an invasive oyster on intertidal assemblage structure and biodiversity: the importance of environmental context and functional equivalency with native species. Marine Biology 165 , 1-13. DOI: $10.1007 / \mathrm{s} 00227-018-3338-7$ 
Fig. 1. Spatial distribution of the sites sampled, groupings for the biogeographic analyses and apparent range shifts. (A) Map of Australia with study region indicated. (B) The 24 mudflats (Appendix Table A.1) sampled (open circles) along the SE Queensland coast in 2016-17. The sites are numbered 1-24 from north to south, and for the purpose of biogeographic analyses are grouped into; (i) those to the north (1-14) and south (15-24) of Cleveland, (ii) into four equal-sized groups from north to south, (iii) the northernmost six (1-6) and southernmost six sites (19-24). (C) The northward biogeographic range shifts for the three temperate taxa. (D) Southward range shifts for crustaceans and foraminifera, and (E) molluscs. The distance and direction shifted is illustrated by grey arrows with the origin and year of most recent record in the Australian Living Atlas (ALA, 2018) and the Ocean Biogeographic Information System (OBIS, 2018). For distances moved (km) see Table 3. For three species (Myrianida australiensis, Laternula anatina and Haminoea fusca) only the current location is provided because the origin falls outside of the sampled area.

Fig. 2. (A) Mean ( \pm SE) macrofaunal density (number of individuals $\mathrm{m}^{-2}$ ), from the 24 mudflats sampled in SE Queensland, Australia (Fig. 1) in winter 2016 (black) and summer 2017 (white). Means are based on five $0.0625 \mathrm{~m}^{2}$ box cores at each site. (B) nMDS ordination of the Bray-Curtis similarity of the macrofaunal species composition ( $\log X+1$ transformed) in each season.

Fig. 3. nMDS ordination of the Bray-Curtis similarity of the mudflat macrofaunal assemblage taxonomic composition (log X+1 transformed density) for mudflats in the northernmost (between Deception Bay and northern Moreton Bay) and southernmost six sites (between Redland Bay and Tallebudgera) sampled in SE Queensland (Fig. 1A), (A) in summer and (B) in winter. Macrofaunal trait composition, weighted by density, (C) in winter and (D) in summer. (E) The mean densities ( \pm SE) of the five taxa contributing most to the SIMPER dissimilarity between the northernmost and southernmost six sites in summer in SE Queensland. *Indicates significance difference.

Fig. 4. (A) The trait modality profiles of taxa based on their typical biogeographic occurrences e.g. tropical, temperate or cosmopolitan. (B) Trait modality profiles of taxa based on the biogeographic occurrences throughout the sampled area (including identified range shifters) in SE Queensland. The species that were absent from the winter assemblage are indicated in 'W'. (C) The trait modalities 
1038 contributed to $>50 \%$ cumulative differences between the trait profiles of temperate taxa that occurred throughout SE Queensland (QId) and tropical range shifters, tropical species that occurred

throughout SE Queensland, tropical species that were absent from the southernmost 6 sites. The traits modalities that differed significantly (Mann-Whitney $U$ test) between three pairs were illustrated in bold, 2 pairs as underlined and an * was added to represent one significant pair.

Fig. 5. nMDS ordination of the Bray-Curtis similarity of the simulated mudflat macrofaunal assemblage trait composition in 24 SE Queensland mudflats under five scenarios of species compositional change 1046 (e.g. pre-invasion, baseline, further invasion, loss of sensitive temperate species and loss of all 1047 temperate species scenarios) (A) in winter, and (B) in summer.

1049 Fig. 6. Estimates for three ecological functions (mean \pm SE) within SE Queensland mudflats under five 1050 scenarios of species compositional change (e.g. pre-invasion, baseline, further invasion, loss of 1051 sensitive temperate species and loss of all temperate species scenarios). Data are standardised to zero 1053 1054 A in both winter and summer. 

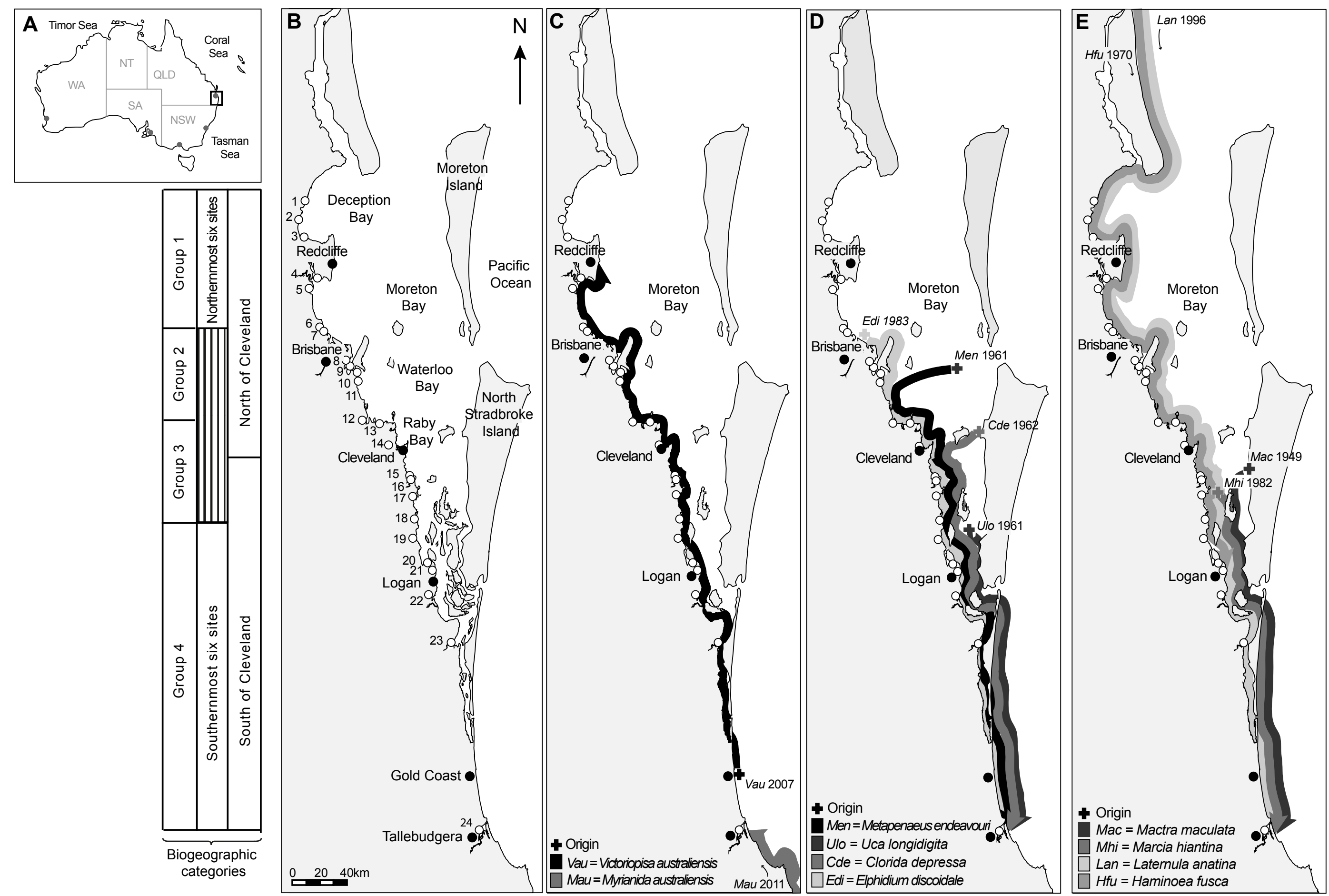

Figure 1 Caswell et al. 2019 

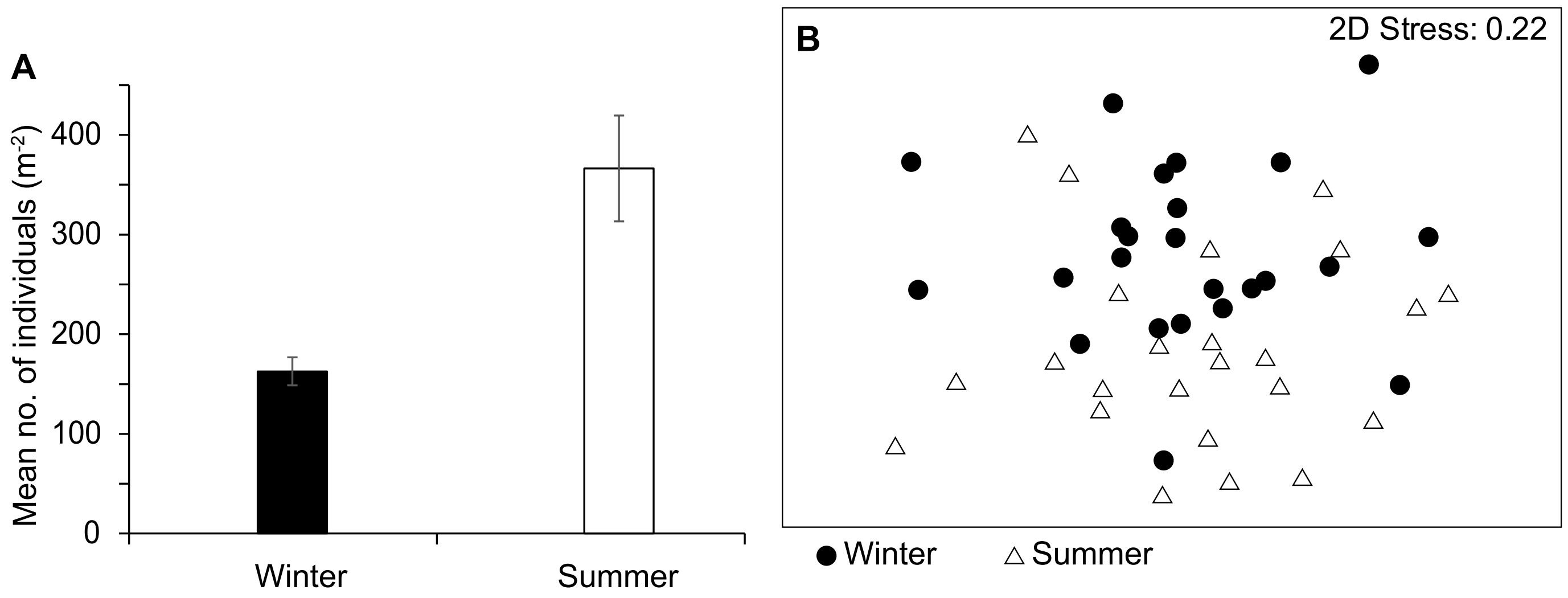

Fig. 2 Caswell et al. 2019 


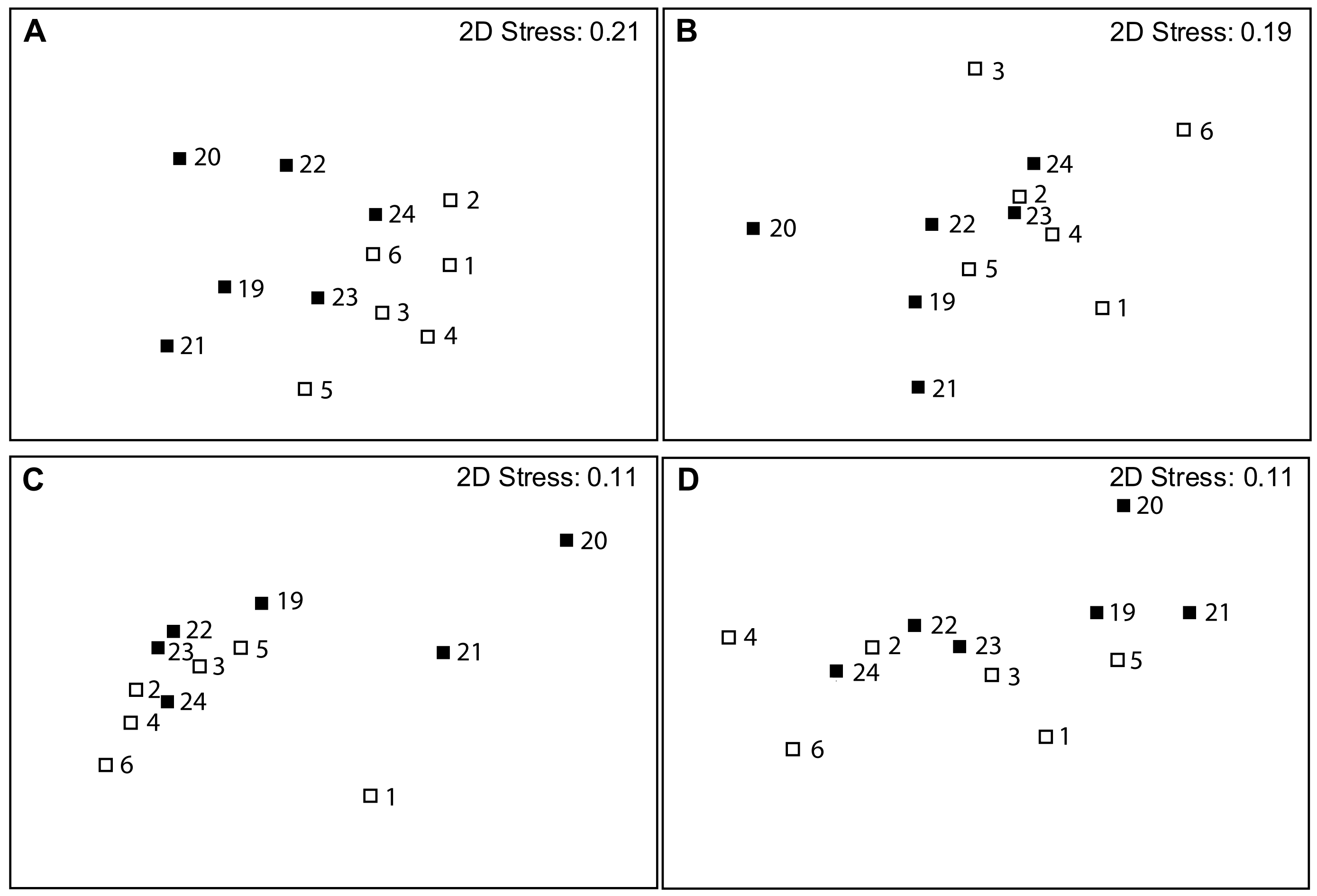

E

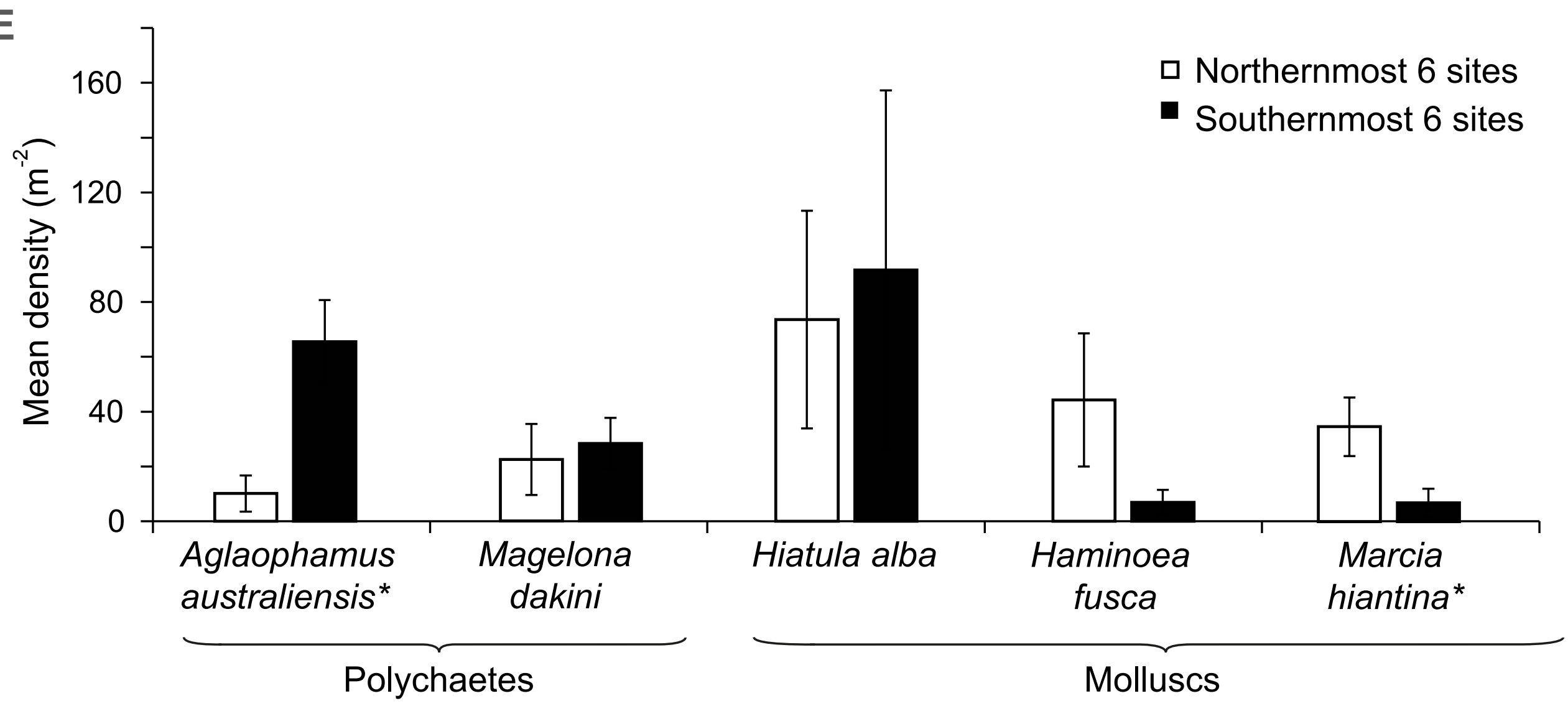

Fig. 3 Caswell et al. 2019 


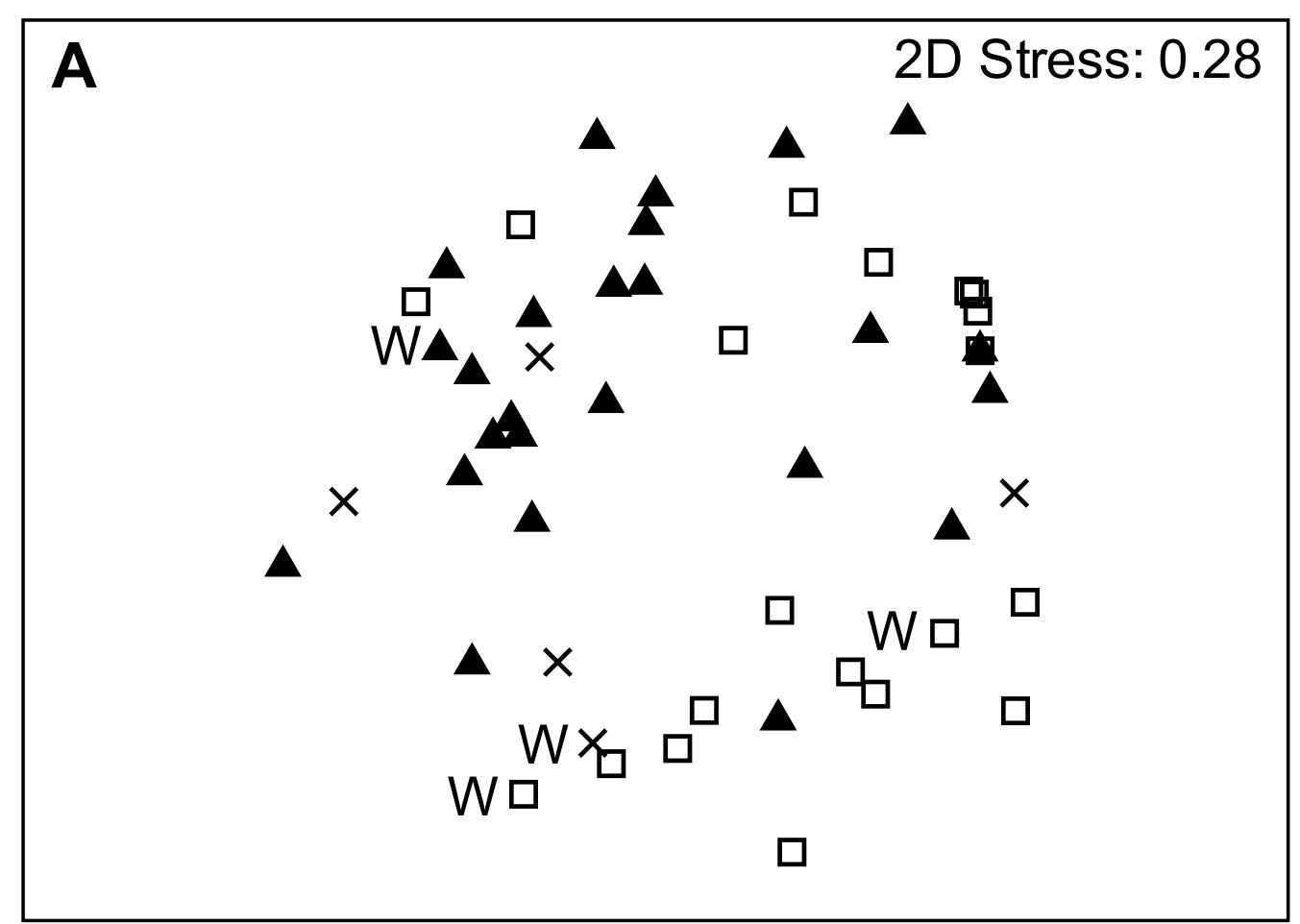

口 Tropical

$\Delta$ Temperate

$\times$ Cosmopolitan

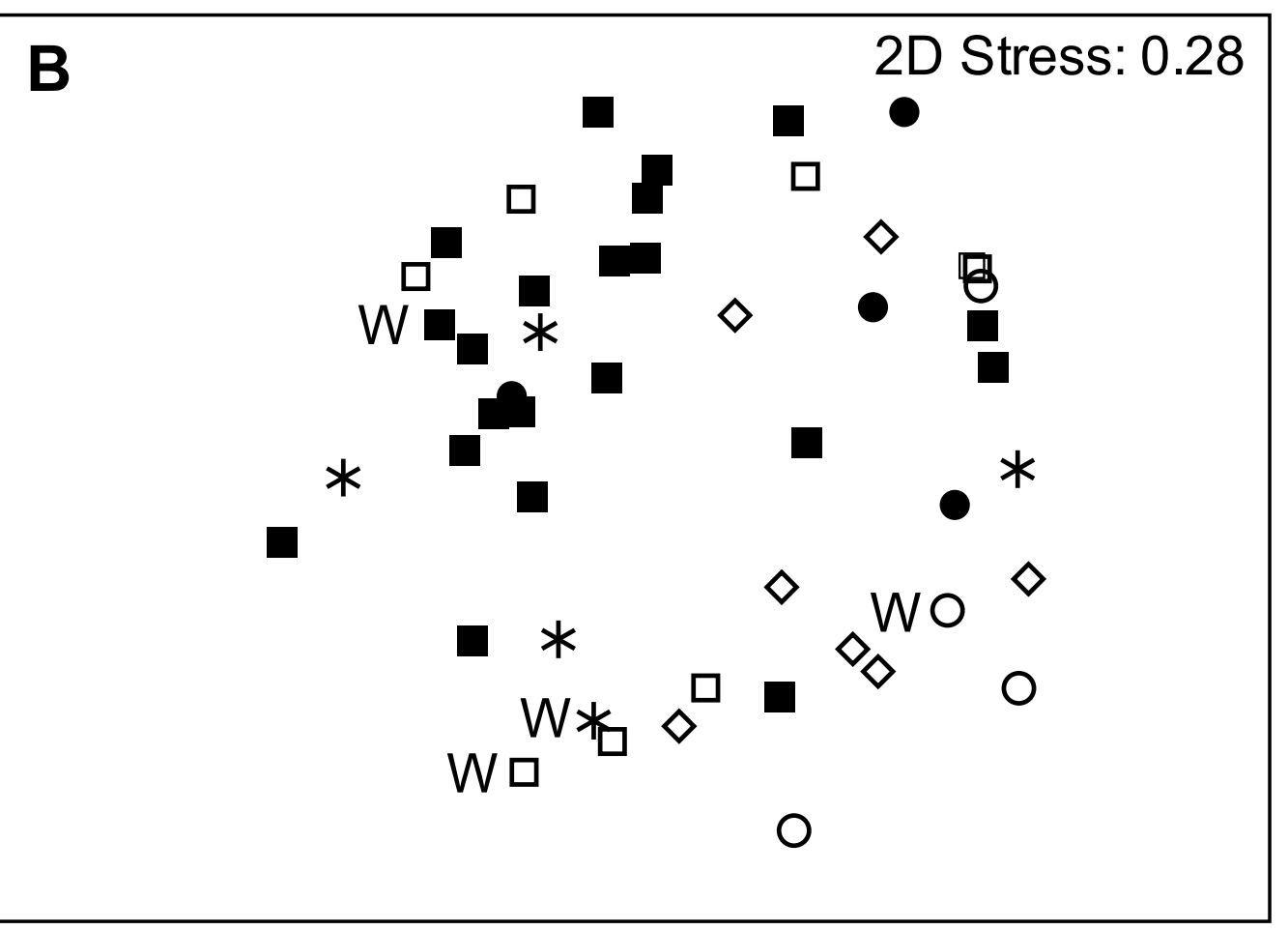

$\diamond$ Tropical range shifters

$\square$ Tropical sp. that occurred throughout SE QId O Tropical sp. absent from southernmost 6 sites * Cosmopolitan species

- Temperate sp. that occur throughout SE QId

- Temperate sp. absent from northernmost 6 sites

C

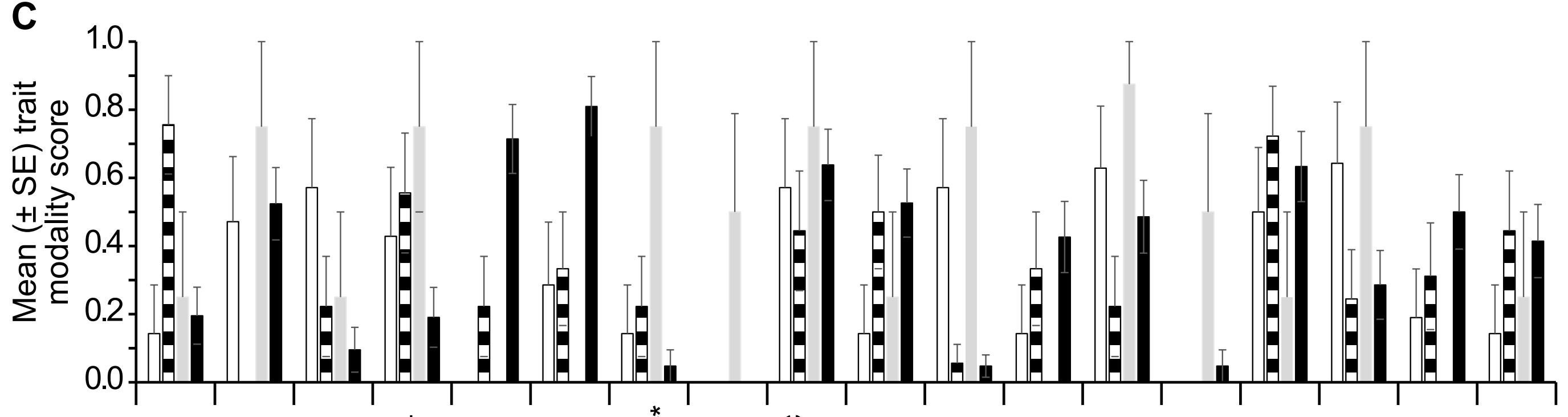

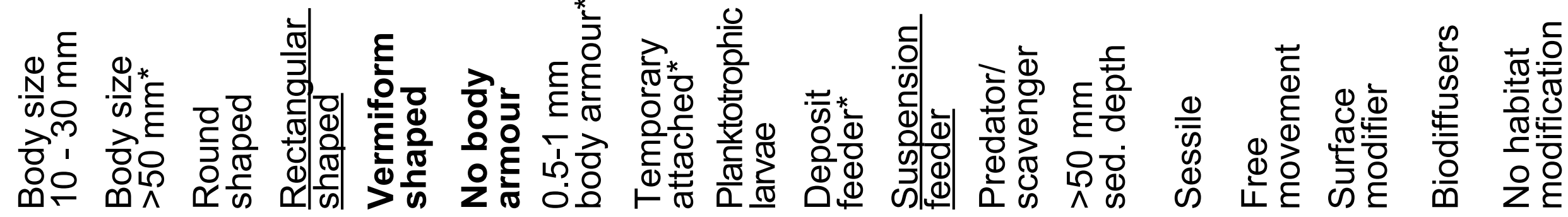

Tropical range shifters

曰 Tropical sp. that occurred throughout SE Qld
Tropical sp. absent from southernmost 6 sites

Temperate sp. that occur throughout SE QId

Fig. 4 Caswell et al. 2020 
A

2D Stress: 0.02

* $\quad$ *

$\Delta \Delta$

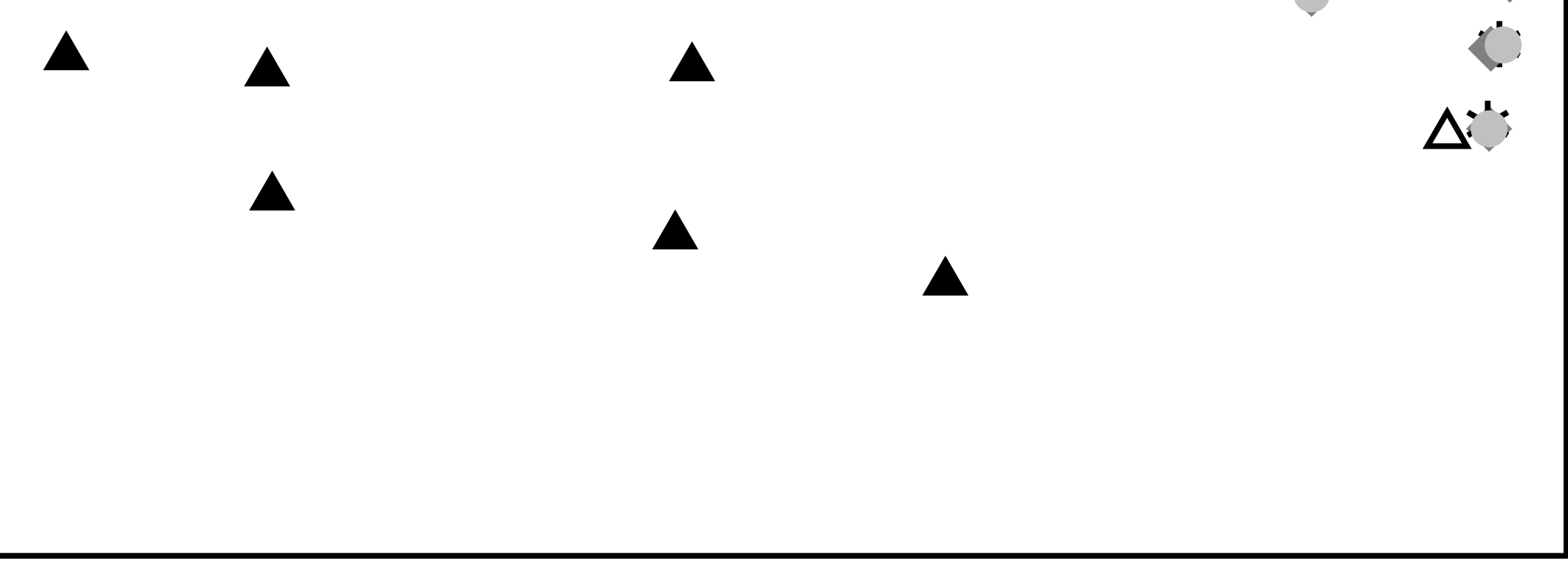

B

2D Stress: 0.03

$\Delta *$

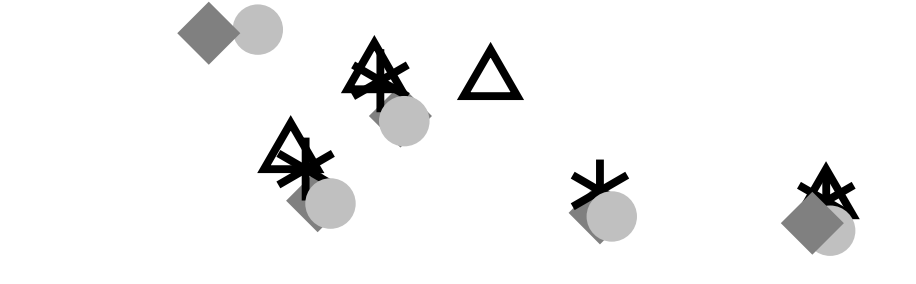

$\Delta$

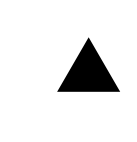

$\Delta$

$\Delta$ Pre-invasion scenario

* Southern baseline scenario

Further invasions scenario

$\diamond$ Loss of sensitive temperate sp. scenario

$\Delta$ Loss of temperate sp. scenario

Fig. 5 Caswell et al. 2020 

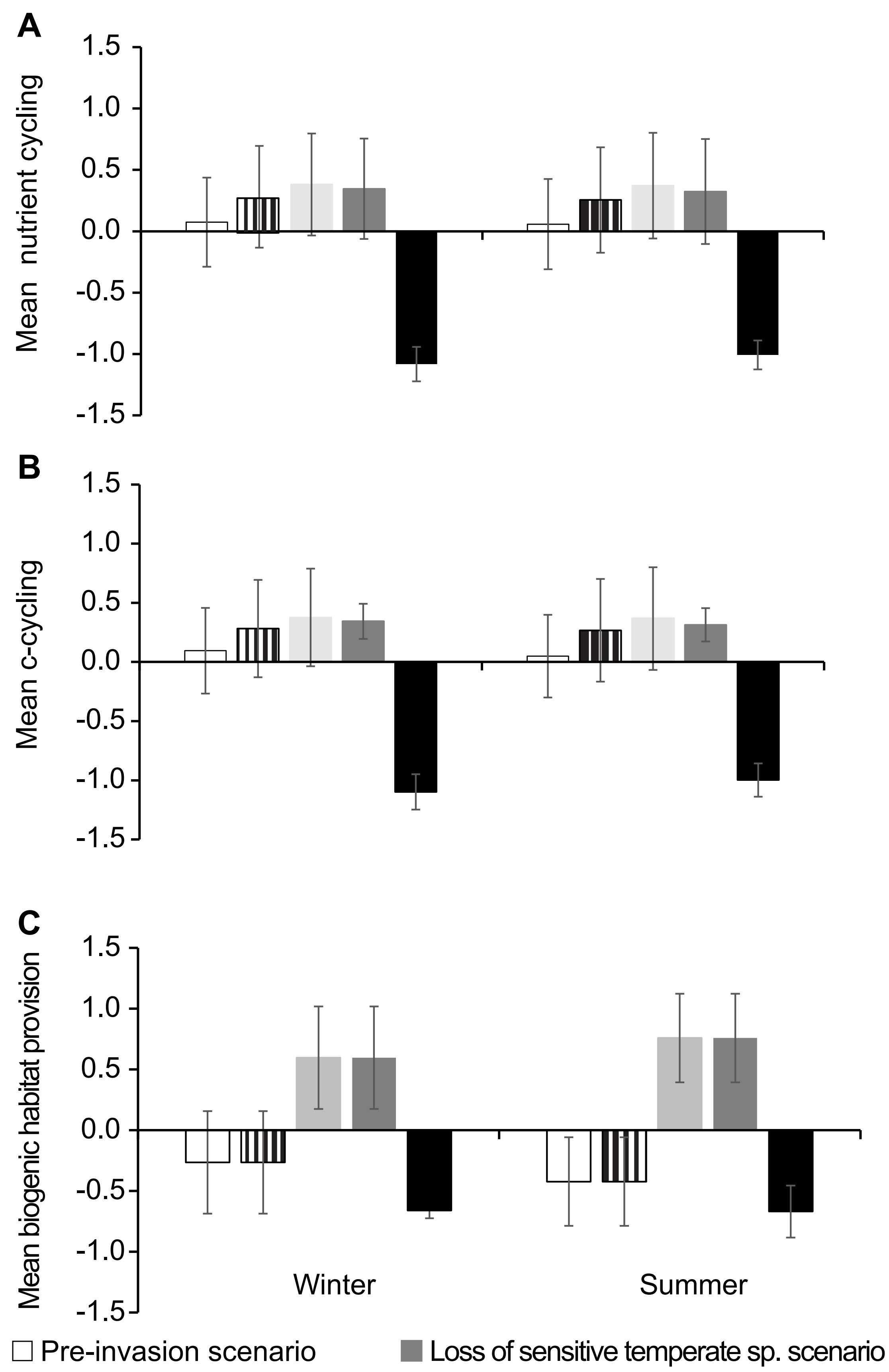

प Southern baseline scenario $\mathbf{\square}$ Loss of all temperate sp. scenaro Further invasion scenario

Fig. 6 Caswell et al. 2020 
Table 1. The eleven biological traits and 45 trait modalities used to characterise the mudflat macrofaunal taxa, and the three ecological functions investigated (and the trait modalities used to index them). Traits were selected to represent a range of morphologies, life histories and behaviours and because they are thought to be important contributors to the three ecological functions (see detailed scientific rationale in Appendix A2). Two models were employed, for model A the value of 1 was assigned for trait modalities with highest affinity to functions and 0 for the lowest contribution. A differentially weighted model (B). was developed where trait modalities varied in their contribution to each function (see Appendix Table A.2).

\begin{tabular}{ll}
\hline Traits & Trait modalities \\
\hline
\end{tabular}

\section{Morphological traits}
A. Maximum adult body size ${ }^{1}$
B. Body shape ${ }^{2}$
C. Body armour thickness
(1) <10 mm; (2) $10-30 \mathrm{~mm}$; (3) $30-50 \mathrm{~mm}$; (4) >50 mm
(1) Round-oval; (2) rectangular-sub-rectangular; (3) vermiform
(1) None; (2) 0.1-0.5 mm; (3) 0.5-1 mm; (4) $1-5 \mathrm{~mm}$; (5) >5 $\mathrm{mm}$

\section{Life history traits}

D. Degree of attachment ${ }^{3}$

E. Longevity

F. Larval development

Behavioural traits

G. Feeding

H. Sediment dwelling depth

I. Adult mobility

J. Sediment reworking 4

K. Habitat modification ${ }^{5}$
(1) None; (2) temporary; (3) permanent

(1) <1 yr; (2) 1-2 yr; (3) 3-5 yr; (4) 5-10 yr; (5) >10 yr

(1) Direct; (2) planktotrophic; (3) lecithotrophic

(1) Deposit feeder; (2) suspension/filter feeder;

(3) predator/scavenger; (4) grazer

(1) Epifauna; (2) 2-20 mm; (3) $20-50 \mathrm{~mm}$; (4) $>50 \mathrm{~mm}$

(1) Sessile/sedentary; (2) limited movement; (3) free movement; (4) swimming

(1) None; (2) surface modifiers; (3) biodiffuser/diffusive mixing; (4) regenerators; (5) upward / downward conveyors

(1) No modification; (2) cast or mound; (3) burrow ditch/hollow; (4) biogenic tubes (5) emergent structures

\begin{tabular}{ll}
\hline Ecological Function $\quad$ Models \\
\hline
\end{tabular}

\section{Nutrient cycling}

Maximum adult body size $>10$ $\mathrm{mm}^{5,6,7}(\mathrm{~A} 2-\mathrm{A} 4)+$ rounded or rectangular body shapes (B1-B2) + deposit or suspension/filter feeders ${ }^{11}(G 1-G 2)+$ sediment dwelling depths $>2 \mathrm{~mm}^{10}(\mathrm{H} 2-\mathrm{H} 4)+$ taxa with adult mobility ${ }^{10}(13)+$ all sediment reworking modes $^{8,9}(\mathrm{~J} 2-$ J5) + taxa that modify habitat by burrowing (K3) ${ }^{10}$

\section{Food web dynamics (C-cycling)}

Taxa of all maximum adult body sizes $^{12}(\mathrm{~A} 1-\mathrm{A} 4)+$ those with body armour $<1 \mathrm{~mm}$ thick ${ }^{14,15}$ (C1-C3) +
Model A: $(\mathrm{A} 2 * 1)+\left(\mathrm{A} 3^{*} 1\right)+(\mathrm{A} 4 * 1)+\left(\mathrm{H} 3^{*} 1\right)+(\mathrm{H} 4 * 1)+$ $(\mathrm{G} 1 * 1)+(\mathrm{G} 2 * 1)+(\mathrm{I} 3 * 1)+(\mathrm{J} 2 * 1)+(\mathrm{J} 3 * 1)+(\mathrm{J} 4 * 1)+\left(\mathrm{J} 5^{*} 1\right)+$ $(\mathrm{H} 2 * 1)+\left(\mathrm{K}^{*} 1\right)+(\mathrm{B} 1 * 1)+(\mathrm{B} 2 * 1)$

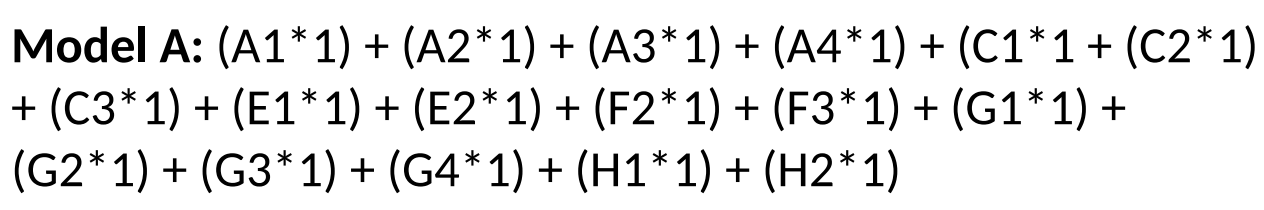

$+(\mathrm{C} 3 * 1)+(\mathrm{E} 1 * 1)+(\mathrm{E} 2 * 1)+(\mathrm{F} 2 * 1)+(\mathrm{F} 3 * 1)+(\mathrm{G} 1 * 1)+$ $(\mathrm{G} 2 * 1)+(\mathrm{G} 3 * 1)+\left(\mathrm{G} 4^{*} 1\right)+\left(\mathrm{H} 1^{*} 1\right)+(\mathrm{H} 2 * 1)$ 
$<2$ year longevity (E1-E2) + all larval

developmental modes ${ }^{13}(\mathrm{~F} 2-\mathrm{F} 3)+$

all feeding modes (G1-G4) + taxa

dwelling at shallow sediment

depths (H1-H2)

\section{Biogenic habitat provision}

Taxa that modify habitat by

Model A: $(K 5 * 1)+(D 2 * 1)+(D 3 * 1)$

creating emergent structures $(\mathrm{K} 5)+$

those that attach to substrates

(D2-D3)

${ }^{1}$ Largest dimension e.g. polychaetes body length, crab carapace width; ${ }^{2}$ Length: width ratio of $B 1=1$ 2; B2 = $3-10$; B3 > 10; ${ }^{3}$ D1 = highly mobile; D2= lives attached to substrate some of the time (e.g., via a weak byssus); D3 = lives permanently attached to hard substrates; ${ }^{4}$ Sediment reworking includes: $\mathrm{J} 1$ = no bioturbation; $\mathrm{J} 2$ = surface modifiers bioturbate sediments near the surface; $\mathrm{J} 3$ = biodiffusors that constantly and randomly mix sediments; $\mathrm{J} 4=$ upward/downward conveyors that feed head up or down and transport sediment from depth to the surface or vice versa; $J 5=$ regenerators that continuously excavate and maintaining burrows (Kristensen et al., 2012; Queirós et al., 2013). ${ }^{5} \mathrm{Habitat}$ modification K4: infaunal tubes. ${ }^{5}$ Bolam et al. (2002); ${ }^{6}$ Thrush et al. (2006); ${ }^{7}$ Norkko et al. (2013); ${ }^{8}$ Biles et al. (2003); ${ }^{9}$ Kristensen et al. (2012); ${ }^{10}$ Mermillod-Blondin et al. (2004); ${ }^{11}$ Welsh (2003); ${ }^{12 Z e u t h e n ~(1953) ; ~}{ }^{13}$ Greve et al. (2004); ${ }^{14}$ Mascaró and Seed (2001); ${ }^{15}$ Boulding (1984) 
Table 2. Five scenarios of changing macrofaunal assemblage composition at the southernmost mudflats (Appendix Fig. B.2) under continued anthropogenic warming in SE Queensland mudflats. The scenarios are based on changes in six categories of taxa in SE Queensland: (A) tropical species that have extended their distribution southwards over the last 20-60 years (tropical range shifters, Fig. 1CD); (B) tropical species that occur throughout SE Queensland; (C) tropical species that currently only occur in the northern sites, but that could shift in the future; (D) robust temperate species whose current range extends throughout SE Queensland; (E) temperate species that are sensitive to temperature change (i.e. did not occur in the northernmost sites); and, (F) cosmopolitan species. Species that were eliminated from the observed baseline community are indicated by 'minus' and those that were added are indicated by 'plus'. Most species were present in both seasons, however for those where adjustments were made in only one season those changes are indicated.

\begin{tabular}{|c|c|c|c|c|c|c|c|c|}
\hline \multirow[t]{3}{*}{ Scenarios } & \multirow[t]{3}{*}{ Description } & \multicolumn{7}{|r|}{ Density manipulations } \\
\hline & & \multicolumn{6}{|c|}{ Species categories } & \multirow[t]{2}{*}{ Species manipulated } \\
\hline & & A & $\mathrm{B}$ & $\mathrm{C}$ & $\mathrm{D}$ & E & $\mathrm{F}$ & \\
\hline $\begin{array}{l}\text { 1. Southern baseline } \\
\text { Describes the current } \\
\text { functioning of mudflats }\end{array}$ & $\begin{array}{l}\text { The current } \\
\text { community. }\end{array}$ & $\mathrm{x}$ & $\mathrm{x}$ & & $x$ & $\mathrm{x}$ & $x$ & No manipulation \\
\hline $\begin{array}{l}\text { 2. Pre-invasion } \\
\text { Describes functioning } \\
\text { prior to the arrival of } \\
\text { tropical range shifters. }\end{array}$ & $\begin{array}{l}\text { The baseline } \\
\text { state without } \\
\text { the tropical } \\
\text { range shifters } \\
\text { (A). }\end{array}$ & & $\mathrm{x}$ & & $\mathrm{x}$ & $\mathrm{x}$ & $\mathrm{x}$ & $\begin{array}{l}\text { Both seasons } \\
\text { - Minus A: E. discoidale, H. fusca, M. hiantina, M. } \\
\text { endeavouri, U. longidigita } \\
\text { Winter } \\
\text { - Minus A: M. maculata } \\
\text { Summer } \\
\text { - Minus A: C. depressa, La. anatina }\end{array}$ \\
\hline $\begin{array}{l}\text { 3. Further invasions } \\
\text { Describes functioning if } \\
\text { more tropical species } \\
\text { invaded. }\end{array}$ & $\begin{array}{l}\text { The baseline } \\
\text { state with the } \\
\text { addition of } \\
\text { tropical species } \\
\text { that might shift } \\
\text { in the future } \\
\text { (C). }\end{array}$ & $x$ & $x$ & $\mathbf{x}$ & $x$ & $x$ & $x$ & $\begin{array}{l}\text { Both seasons } \\
\text { - Plus C: L. impar, Li. anatina, T. polita } \\
\text { Summer } \\
\text { - Plus C: P. undulatus, }\end{array}$ \\
\hline $\begin{array}{l}\text { 4. Loss of sensitive } \\
\text { temperate taxa } \\
\text { Describes functioning if } \\
\text { more tropical species } \\
\text { invaded AND sensitive } \\
\text { temperate taxa were lost. }\end{array}$ & $\begin{array}{l}\text { Scenario } 3 \\
\text { without } \\
\text { sensitive } \\
\text { temperate } \\
\text { species (E). }\end{array}$ & $x$ & $x$ & $x$ & $x$ & & $x$ & $\begin{array}{l}\text { Both seasons } \\
\text { - Plus C: Li. anatina, L. impar, T. polita } \\
\text { - Minus E: A. sibogae, H. haswellianus, } \\
\text { T. australiensis } \\
\text { Summer } \\
\text { - Minus E: S. boa } \\
\text { - Plus C: P. undulata }\end{array}$ \\
\hline $\begin{array}{l}\text { 5. Loss of all temperate } \\
\text { taxa } \\
\text { Describes functioning if } \\
\text { temperate species were } \\
\text { lost and only tropical } \\
\text { species remained. }\end{array}$ & $\begin{array}{l}\text { Scenario } 3 \\
\text { without any } \\
\text { temperate } \\
\text { species (D or E). }\end{array}$ & $x$ & $x$ & $x$ & & & $\mathrm{x}$ & $\begin{array}{l}\text { Both seasons } \\
\text { - Plus C: Li. anatina, L. impar, T. polita } \\
\text { - Minus D: A. australiensis, A. richardsoni, A. } \\
\text { intermedia, A. ehlersi, B. lepte, C. punctulatum, } \\
\text { G. americana, H. alba, L. bifurcatus, L. tetraura, } \\
\text { M. setosus, M. dakini, M. mullawa, M. } \\
\text { australiensis, O. australis, P. novaehollandiae, } \\
\text { V. australiensis } \\
\text { - Minus E: A. sibogae, H. haswellianus, T. } \\
\text { australiensis } \\
\text { Summer } \\
\text { - Plus C: P. undulata } \\
\text { - Minus D: N. torquatus, P. antipoda, S. miersi } \\
\text { - Minus E: S. boa }\end{array}$ \\
\hline
\end{tabular}


Table 3: The biogeographic ranges of the 50 taxa (summer and winter combined) found in the 24 mudflats sampled during this study, and their known latitudinal ranges in Australia as documented from published databases (ALA, 2018; OBIS, 2018). (Globally documented latitudinal ranges are provided in Appendix B.3, NB: these do not affect the range shifts documented herein). These new data extended the ranges of 10 species (bold rows), and for these species the year (the latest date the shift could have begun), extent and direction of the expansion is provided. The 'typical' climatic zone of each species based on previous records is given using: the tropical climatic zones defined as $23^{\circ} 27^{\prime} \mathrm{S}$ in Dissanayake et al. (2018), and the temperate climatic zone boundary $\left(32.4^{\circ} 00^{\prime} \mathrm{S}\right)$ was based on the southern boundary of Moreton-Tweed marine ecoregion described by Spalding et al. (2007) and the convergence of the Australian East Coast Current and the Tasman Sea Current (Cetina-Heredia et al., 2014). Abbreviations: Trop = Tropical, Temp $=$ Temperate, $\mathrm{N}=$ number of sites/records.

\begin{tabular}{|c|c|c|c|c|c|c|c|c|c|c|}
\hline \multirow[t]{2}{*}{ Species } & \multirow[t]{2}{*}{$\begin{array}{l}\text { Sp. } \\
\text { zone }\end{array}$} & \multicolumn{3}{|c|}{$\begin{array}{l}\text { Max. documented latitudinal } \\
\text { range }\left(^{\circ}\right) \text { of taxa }\end{array}$} & \multicolumn{4}{|c|}{$\begin{array}{l}\text { Latitudinal range of taxa at } 24 \\
\text { mudflats sampled }\end{array}$} & \multirow{2}{*}{$\begin{array}{c}\text { Distance \& } \\
\text { direction } \\
\text { moved } \\
(\mathrm{km})\end{array}$} & \multirow{2}{*}{$\begin{array}{c}\text { Rate } \\
(\mathrm{km} \\
\left.\text { decade }^{-1}\right)\end{array}$} \\
\hline & & Year & North & South & $\mathbf{N}$ & North & South & $\mathbf{N}$ & & \\
\hline Acetes sibogae $e^{2}$ & Temp & & -15.2250 & -36.2070 & 174 & -27.3436 & -28.1069 & 12 & & \\
\hline Aglaophamus australiensis & Temp & & -17.0330 & -43.0330 & 1093 & -27.1464 & -28.1069 & 23 & & \\
\hline Alpheus richardsoni ${ }^{2}$ & Temp & & -16.7660 & -41.4660 & 143 & -27.1747 & -28.1069 & 9 & & \\
\hline Armandia intermedia ${ }^{2}$ & Temp & & -19.1160 & -38.8500 & 285 & -27.1747 & -28.1069 & 16 & & \\
\hline Australonereis ehlersi & Temp & & -23.1830 & -42.2752 & 566 & -27.1464 & -28.1069 & 12 & & \\
\hline Australoplax tridentata & Trop & & -10.7333 & -36.2078 & 83 & -27.1956 & -28.1069 & 14 & & \\
\hline Barantolla lepte & Temp & & -22.3830 & -38.8500 & 791 & -27.1747 & -27.8222 & 18 & & \\
\hline Bulla vernicosa ${ }^{2}$ & Trop & & -23.9000 & -34.7500 & 430 & -27.2597 & -28.1069 & 3 & & \\
\hline Chaenostoma punctulatum & Temp & & -10.7160 & -36.0653 & 58 & -27.1464 & -28.1069 & 14 & & \\
\hline Cirriformia tentaculata ${ }^{2}$ & Temp & & -22.3830 & -42.8800 & 82 & -27.1747 & -27.6436 & 6 & & \\
\hline Clorida depressa ${ }^{2}$ & Trop & 1998 & -21.2350 & -27.6667 & 59 & -27.1956 & -27.7178 & 5 & $6 S$ & 3 \\
\hline Conuber sordidum ${ }^{2}$ & All & & -10.6000 & -43.1179 & 544 & -27.1464 & -28.1069 & 21 & & \\
\hline Elphidium discoidale ${ }^{1}$ & Trop & 1983 & -20.9000 & -24.6814 & 2 & -27.1747 & -28.1069 & 7 & $381 \mathrm{~S}$ & 112 \\
\hline Eurysyllis tuberculata ${ }^{2,4}$ & Trop & & -14.5723 & -34.7500 & 31 & -27.1747 & -27.7178 & 6 & & \\
\hline Gelasimus vomeris ${ }^{2}$ & Trop & & -23.4122 & -33.8083 & 145 & -27.2775 & -28.1069 & 10 & & \\
\hline Glycera americana ${ }^{2}$ & Temp & & -22.3830 & -41.1600 & 515 & -27.1956 & -27.8222 & 12 & & \\
\hline Haminoea fusca ${ }^{4}$ & Trop & 1970 & -14.6700 & -25.2500 & 16 & -27.1747 & -28.1069 & 16 & $317 \mathrm{~S}$ & 68 \\
\hline Helograpsus haswellianus² & Temp & & -9.5833 & -43.0300 & 207 & -27.3436 & -27.8222 & 10 & & \\
\hline Hiatula alba & Temp & & -26.7660 & -43.4630 & 69 & -27.1464 & -28.1069 & 18 & & \\
\hline Laternula anatina ${ }^{2,4}$ & Trop & 1996 & -16.5500 & -23.4160 & 103 & -27.1956 & -27.7053 & 5 & $477 \mathrm{~S}$ & 227 \\
\hline Leitoscoloplos bifurcatus & Temp & & -14.6794 & -42.3902 & 489 & -27.1464 & -28.1069 & 12 & & \\
\hline Lingula anatina & Trop & & -20.4000 & -27.9667 & 47 & -27.2597 & -27.5158 & 2 & & \\
\hline Lumbrineris tetraura ${ }^{2}$ & Temp & & -28.1903 & -38.7300 & 716 & -27.1747 & -28.1069 & 12 & & \\
\hline Lutraria impar ${ }^{2}$ & Trop & & -23.2000 & -28.3803 & 24 & -27.1956 & -27.4764 & 4 & & \\
\hline Macrophthalmus setosus & Temp & & -22.3833 & -36.0612 & 133 & -27.1747 & -28.1069 & 21 & & \\
\hline Mactra maculata ${ }^{2,3}$ & Trop & 1949 & -14.6600 & -27.5830 & 61 & -27.1463 & -28.1069 & 17 & $58 \mathrm{~S}$ & 9 \\
\hline Magelona dakini & Temp & & -18.7330 & -41.1612 & 371 & -27.1464 & -28.1069 & 19 & & \\
\hline Marcia hiantina ${ }^{2}$ & Trop & 1982 & -23.1827 & -27.6167 & 250 & -27.1464 & -28.1069 & 16 & $54 \mathrm{~S}$ & 16 \\
\hline Marphysa mullawa & Temp & & -12.6660 & -36.8917 & 122 & -27.1747 & -28.1069 & 9 & & \\
\hline Metapenaeus endeavouri² & Trop & 1961 & -23.8450 & -27.4167 & 2395 & -27.2775 & -28.1069 & 8 & $77 \mathrm{~S}$ & 14 \\
\hline Mictyris longicarpus ${ }^{2}$ & All & & -11.9000 & -38.4612 & 342 & -27.1464 & -28.1069 & 20 & & \\
\hline Myrianida australiensis & Temp & 2011 & -30.5409 & -30.5409 & 1 & -27.1747 & -27.7503 & 11 & $374 \mathrm{~N}$ & 623 \\
\hline Nassarius coronatus ${ }^{2}$ & Trop & & -23.1300 & -34.2544 & 299 & -27.2597 & -27.7503 & 4 & & \\
\hline Nematoda ${ }^{2}$ & All & & -16.1333 & -41.7339 & 30516 & -27.1464 & -28.1069 & 20 & & \\
\hline Nemertea $^{2}$ & All & & -14.5000 & -54.7083 & 3202 & -27.1747 & -28.1069 & 13 & & \\
\hline Notomastus torquatus & Temp & & -23.8160 & -38.4889 & 493 & -27.1464 & -28.1069 & 21 & & \\
\hline Owenia australis & Temp & & -14.6700 & -38.9000 & 248 & -27.1464 & -28.1069 & 21 & & \\
\hline Paratapes undulatus ${ }^{2}$ & Trop & & -23.3330 & -36.9033 & 230 & -27.1956 & -27.5158 & 2 & & \\
\hline $\begin{array}{l}\text { Phyllodoce } \\
\text { novaehollandiae }\end{array}$ & Temp & & 19.8830 & -38.7661 & 108 & -27.1464 & -28.1069 & 16 & & \\
\hline Platynereis antipoda ${ }^{2}$ & Temp & & 10.5863 & -43.4350 & 385 & -27.2775 & -27.7178 & 6 & & \\
\hline Prionospio queenslandica ${ }^{4}$ & Trop & & 10.5861 & -35.7461 & 17 & -27.1463 & -27.7178 & 11 & & \\
\hline Pyrazus ebeninus & All & & 10.6830 & -42.9111 & 380 & -27.1464 & -28.1069 & 22 & & \\
\hline Recluzia johnii ${ }^{3}$ & Trop & & 23.4167 & -34.0583 & 11 & -27.7178 & -27.7503 & 2 & & \\
\hline Stenothoe miersi & Temp & & 14.5719 & -37.8898 & 48 & -27.1747 & -28.1069 & 8 & & \\
\hline
\end{tabular}




\begin{tabular}{|c|c|c|c|c|c|c|c|c|c|c|}
\hline Sternaspis scutata ${ }^{2,4}$ & Trop & & 23.8500 & -32.5000 & 3177 & -27.3436 & -27.7503 & 7 & & \\
\hline Sthenelais boa ${ }^{2}$ & Temp & & 27.1189 & -34.0083 & 3971 & -27.5158 & -27.8222 & 4 & & \\
\hline Trypaea australiensis & Temp & & 17.7833 & -38.7000 & 651 & -27.395 & -28.1069 & 6 & & \\
\hline Tubuca polita ${ }^{2}$ & Trop & & 22.1167 & -30.8830 & 102 & -27.2775 & -27.2775 & 1 & & \\
\hline Uca longidigita & Trop & 1962 & 21.1333 & -27.5000 & 27 & -27.4222 & -27.7503 & 4 & $28 \mathrm{~S}$ & 5 \\
\hline Victoriopisa australiensis ${ }^{3}$ & Temp & 2007 & 27.9160 & -37.0963 & 186 & -27.1464 & -27.7503 & 11 & $85 \mathrm{~N}$ & 86 \\
\hline
\end{tabular}

${ }^{1}$ The range given is for $E$. discoidale, however this record could potentially be confounded as subspecies Elphidium discoidale var. multiloculum was described from Moreton Bay (-27.1108 to -27.6583) by Narayan and Pandolfi (2010). If this is-variety is confirmed as a distinct taxon then the record in the present study may not represent a range shift for the species. ${ }^{2}$ Species that have different global ranges (see Appendix Table B.3). ${ }^{3}$ Taxa previously recorded only once within the study area. ${ }^{4}$ Taxa not previously recorded in the study area (and only once in greater SE Queensland). 
We declare no conflict of interest 
Bryony Caswell: Conceptualisation, methodology, Writing original draft preparation, Writing- review and editing, visualization, supervision

Navodha Dissanayake: Data curation, Writing original draft preparation, formal analysis, investigation, visualization

Chris Frid: Conceptualisation, methodology, Writing- review and editing, Resources, supervision, validation 
[Type here]

\section{Appendix A: Materials \& methods}

\section{A.1 Geographic locations of the study site}

Table A.1. The geographic coordinates of the 24 subtropical mudflats along the SE Queensland coast (negative latitudes indicate $S$ of the equator) (Fig. 1).

\begin{tabular}{ccc}
\hline Site no & Latitude (degrees) & Longitude (degrees) \\
\hline $\mathbf{1}$ & -27.8222 & 153.0464 \\
$\mathbf{2}$ & -27.1747 & 153.0319 \\
$\mathbf{3}$ & -27.1956 & 153.0431 \\
$\mathbf{4}$ & -27.2597 & 153.0747 \\
$\mathbf{5}$ & -27.2775 & 153.0369 \\
$\mathbf{6}$ & -27.3436 & 153.0933 \\
$\mathbf{7}$ & -27.3425 & 153.1000 \\
$\mathbf{8}$ & -27.3947 & 153.1391 \\
$\mathbf{9}$ & -27.3950 & 153.1583 \\
$\mathbf{1 0}$ & -27.3933 & 153.1689 \\
$\mathbf{1 1}$ & -27.4222 & 153.1706 \\
$\mathbf{1 2}$ & -27.4764 & 153.2033 \\
$\mathbf{1 3}$ & -27.4808 & 153.2422 \\
$\mathbf{1 4}$ & -27.5158 & 153.2622 \\
$\mathbf{1 5}$ & -27.5739 & 153.3056 \\
$\mathbf{1 6}$ & -27.5622 & 153.3003 \\
$\mathbf{1 7}$ & -27.6019 & 153.3019 \\
$\mathbf{1 8}$ & -27.6436 & 153.3119 \\
$\mathbf{1 9}$ & -27.6589 & 153.3092 \\
$\mathbf{2 0}$ & -27.7053 & 153.3239 \\
$\mathbf{2 1}$ & -27.7178 & 153.3539 \\
$\mathbf{2 2}$ & -27.7503 & 153.3511 \\
$\mathbf{2 3}$ & -27.8222 & 153.3781 \\
$\mathbf{2 4}$ & -28.1069 & 153.4464 \\
\hline
\end{tabular}

\section{A.2 Simulating species taxonomic and trait change and the effects on mudflat ecological functioning}

Analyses were performed on both unconstrained and constrained data sets. In the latter case all of the simulated assemblage data were standardised to the same total density to aid comparisons between the five scenarios emphasising the influence of the changing species compliment rather than changes in the size of the assemblage (Table 2). This was prompted because biological traits analysis uses the total density of each trait modality to characterise an assemblage and so is sensitive to the total number of individuals within an assemblage. As we have no simple means of predicting changes in the relative densities of taxa, our constrained simulations capture changing species composition from the mean densities of the species within their observed range (i.e. the mean number of individuals/biomass recorded across the southernmost six sites during each season rounded to the 
[Type here]

nearest 10). The macrofaunal assemblages were standardised to a total of 390 individuals per $\mathrm{m}^{2}$ in the summer and 160 individuals per $\mathrm{m}^{2}$ in winter.

Two models ( $A$ and $B$ ) were used to explore the implications of species losses and gains from the macrofaunal assemblages of the southernmost SE Queensland mudflats sampled in this study. Model A included the trait modalities thought to make a contribution to each functions and these were effectively assigned a weighting of 1 (Frid and Caswell, 2016)(Table 1). An additional model (model B) employing differential weightings on these traits, to better reflect our, partial, understanding of the contribution of each trait modality to a particular function was also developed. For instance, macrofauna with large body sizes contribute proportionally more to some functions than smaller individuals (Norkko et al., 2013; Thrush et al., 2006). The differential weightings were derived based on known relationships between the biological traits of species and the level of ecological functioning delivered (see justification below). For both models the selected trait modalities, weighted by density, were summed separately for each function and each scenario.

Nutrient cycling. In coastal seas nutrient cycling is strongly coupled with benthic processes that regenerate nitrogen compounds from within intertidal and subtidal sediments and this can provide $20-100 \%$ of the annual $\mathrm{N}$ requirements for water column primary production (Welsh, 2003). Mudflats are recognised sources and sinks for organic matter and nutrients, with the direction and magnitude of these fluxes being determined by the resident macroinvertebrate, benthic primary producers and the microbial communities (D'Andrea and DeWitt, 2009). Microbes oxidise organic matter and transform elements through a series of oxidation and reduction reactions which in turn drive the biogeochemical cycling of nutrients in coastal waters facilitating pelagic primary production (Worden et al., 2015). The composition of the sedimentary microbial community and the rates of their metabolic processes are strongly influenced by local environmental conditions (Welsh 2003; Thrush et al. 2006), in particular the sediment redox state and availability of (labile) organic material (Piepenburg et al., 1995; Van Oevelen et al., 2006) (In coastal systems macrofauna facilitate the mineralization of sedimentary $\mathrm{N}$ and the efflux of the mineralization products into the water column. These fluxes are fourfold higher when macrobenthos are present compared with when they are not (Hansen and Blackburn, 1992; Kristensen and Blackburn, 1987; Welsh, 2003). Macrofauna facilitate nutrient cycling through a combination of biological traits such as sediment reworking which is mainly driven by the feeding, movement and behaviour of macroinvertebrates. These processes oxygenate the sediment, enhance the vertical transfer of organic matter, establish concentration 
[Type here]

gradients, increase the sediment surface area for chemical exchange with the water column (Fenchel, 1996) and influence the composition of meiofaunal and microbial communities (Fenchel and Finlay, 2008; Olafsson, 2003; Warwick and Clarke, 1984). Those with surface modifying and biodiffusive mixing traits perform constant and random local sediment mixing over short distances and make similar contributions to nutrient efflux. For instance, biodiffusive mixing by Nereis diversicolor and surface modifying behaviour of Corophium volutator and Macoma balthica contribute 21-38 $\mathrm{NH}_{4}-\mathrm{N} \mu \mathrm{mol} \mathrm{L}^{-1}$ to nutrient effluxes (Biles et al., 2003). However, other bioturbatory modes such as sediment regenerators and upward/downward conveyors make greater contributions to sediment mixing and nutrient effluxes than surface modifiers or biodiffusors. The upward conveyors callianassid shrimps move deep sediment to the surface at a rate of $12 \mathrm{~kg} \mathrm{~m}^{-2} \mathrm{~d}^{-1}$ (Branch and Pringle, 1987) releasing 50-60 $\mathrm{NH}_{4}-\mathrm{N} \mathrm{\mu mol} \mathrm{L}^{-1}$ (Nates and Felder, 1998). Whereas, regenerators continuously excavate sediment through digging and maintaining burrows (Kristensen et al., 2012) e.g. Uca sp. burrow $>10 \mathrm{~cm}$, excavating $\sim 10 \mathrm{~g}$ of sediment per day (Penha-Lopes et al., 2009) contributing between 650 and $800 \mathrm{NH}_{4}-\mathrm{N} \mathrm{\mu mol} \mathrm{L}^{-1}$ to the overlying waters. Thus, these traits were used to index nutrient cycling (Table 1) and included organisms with an adult body size $>10$ $\mathrm{mm}$ and more rounded/rectangular morphology that have the potential to overturn (or displace) larger amounts of sediment than those of smaller body size or more vermiform shape (Table 1 , Norkko et al., 2013; Thrush et al., 2006). Similarly, mobile organisms and those that burrow have greater potential to disturb the sediment (Mermillod-Blondin et al., 2004), with some feeding and bioturbatory modes having greater influence upon sediment nutrient cycling and for this reason were weighted by their ability to disturb surface and subsurface sediments, irrigate their burrows (suspension feeders; Kristensen et al., 2012; Welsh, 2003) and mechanically degrade organic matter (Clare et al., 2015, Table 1; Welsh, 2003).

Food-web dynamics (C-cycling). The cycling of organic $\mathrm{C}$ in marine systems is driven by food-web dynamics (ingestion, respiration, production) and reproductive processes. Macrofaunal communities mediate the transport, transformation and storage of carbon within an ecosystem. Within sediments macrofauna may contribute between $11 \%$ and $43 \%$ of total benthic community respiration with the remainder being from bacteria and microbenthos (Piepenburg et al., 1995; Van Oevelen et al., 2006). Benthic macrofaunal C-cycling was therefore indexed by organisms of all body sizes, all feeding modes, and dispersive reproductive modes (these traits would move $\mathrm{C}$ around the wider ecosystem, and between the benthic and pelagic realm, more than direct developers where $C$ from the adult is packaged into young and retained locally; Greve et al., 2004). In Model B this function was weighted towards larger-sized organisms (Table 2) that individually consume and respire more 
[Type here]

and thus cycle more C (Norkko et al., 2013; Zeuthen, 1953). A differential weighting was further applied to larger taxa that are more likely to be predated by higher trophic level consumers (Thrush et al., 2006) and so may contribute more towards wider ecosystem carbon cycling. Similarly, taxa that lack or have only a thin exoskeleton and those that only burrow to shallow sediment depths will be more regularly predated and so contribute more to C-cycling than those which have more substantial protection from, or more effectively avoid, predators. Deposit feeders ingest sediment containing organic matter that enters back into the environment through faeces recycling carbon (Wilson et al., 1993). Suspension feeders were weighted above the other feeding modes because they feed on suspended particulate organic carbon in the water column and so draw carbon into the benthic realm facilitating benthic-pelagic coupling (Smaal and Prins, 1993) compared with other feeding modes that cycle carbon within the sediment only. Species with shorter life-spans cycle more carbon through the food web (REF) as they are regularly consumed and decomposed. Whereas, longer-lived, usually larger organisms, retain organic carbon within their body tissues throughout their lives. and so shorter-lived taxa ( $<2$ years) were included in estimates of C-cycling.

Biogenic habitat provision. Biological structures such as mussel beds, oyster reefs and kelp forests may have a substantial influence on local species diversity by increasing habitat heterogeneity (Bracken, 2018; Buhl-Mortensen et al., 2010) and providing important refuges and nursery habitat. For example, the polychaete Diopatra cuprea builds emergent leathery tubes incorporating fragmented bivalve shells, and so it provides hard substrates for the growth of macroalgae creating further habitat (Thomsen and McGlathery, 2005). In this way the biological activities of one organism e.g. the creation of casts, mounds or burrows can provide habitat or shelter from predators, and structures that emerge from the sediment may provide hard substrates for attachment. Taxa with such traits may act as ecosystem engineers whereby the biogenic tubes trap sediment and provide sediment stability (Rabaut et al., 2007) altering local sediment properties and organic content. Biogenic habitats are constructed by organisms that are sessile and have an attached epifaunal life habit and so this function was indexed by taxa that attach themselves to substrates and produce the emergent structures (Table 1). 
[Type here]

Table A.1. The three ecological functions investigated (and the trait modalities used to index them) for the subtropical SE Queensland mudflats. Two models were employed an unweighted 'baseline' (model A), and a differentially weighted model (B) where trait modalities vary in their contribution to each function. Differential weightings were developed from Frid and Caswell (2016).

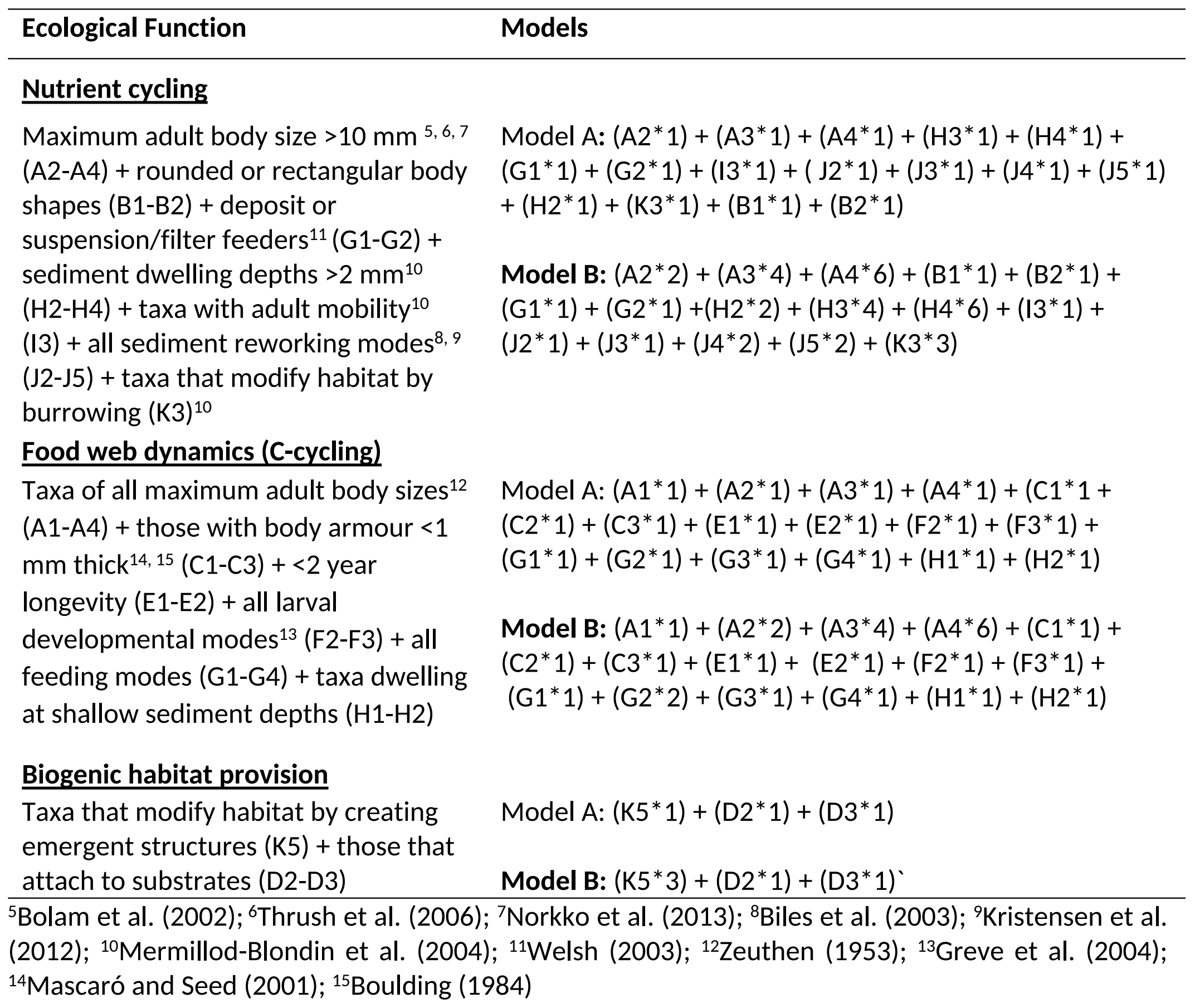


[Type here]

\section{Appendix B: Results}

\section{B.1 Macrofaunal assemblages of mudflats in SE Queensland}

The total number of individuals recorded across the 24 sites were higher in summer $(n=3047)$ compared to winter $(n=1800)$. In both seasons 10 taxa contributed to $70 \%$ of the cumulative macrofaunal density in the assemblage (Appendix Table B.1). In summer the suspension feeding bivalve Hiatula alba dominated, followed by the polychaetes Barantolla lepte and Aglaophamus australiensis. Whereas in winter the crabs Mictyris longicarpus and Macrophthalmus setosus dominated the assemblage.

Table B.1. The top 10 taxa (ranked by abundance) as a percentage of the total number of individuals retrieved in winter (2016) and summer (2017) from the 24 SE Queensland mudflats.

\begin{tabular}{|c|c|c|c|}
\hline \multicolumn{2}{|l|}{ Summer 2017} & \multicolumn{2}{|l|}{ Winter 2016} \\
\hline Taxa & $\begin{array}{l}\text { Abundance } \\
\text { (\%) }\end{array}$ & Taxa & $\begin{array}{l}\text { Abundance } \\
\text { (\%) }\end{array}$ \\
\hline Hiatula alba (bivalve) & 14.8 & Mictyris longicarpus (decapod) & 10.4 \\
\hline Barantolla lepte (polychaete) & 9.8 & $\begin{array}{l}\text { Macrophthalmus setosus } \\
\text { (decapod) }\end{array}$ & 10.1 \\
\hline $\begin{array}{l}\text { Aglaophamus australiensis } \\
\text { (polychaete) }\end{array}$ & 9.7 & Barantolla lepte (polychaete) & 9.7 \\
\hline $\begin{array}{l}\text { Elphidium discoidale } \\
\text { multilocutum (foraminifera) }\end{array}$ & 9.4 & $\begin{array}{l}\text { Aglaophamus australiensis } \\
\text { (polychaete) }\end{array}$ & 9.2 \\
\hline $\begin{array}{l}\text { Macrophthalmus setosus } \\
\text { (decapod) }\end{array}$ & 5.5 & Hiatula alba (bivalve) & 8.2 \\
\hline Magelona dakini (polychaete) & 4.5 & Pyrazus ebeninus (gastropod) & 6.8 \\
\hline $\begin{array}{l}\text { Notomastus torquatus } \\
\text { (polychaete) }\end{array}$ & 3.8 & Magelona dakini (polychaete) & 4.3 \\
\hline Marcia hiantina (bivalve) & 3.6 & Owenia australis (polychaete) & 4.1 \\
\hline Haminoea fusca (gastropod) & 3.6 & Uca vomeris (decapod) & 4.0 \\
\hline Nematoda & 3.4 & Notomastus torquatus (polychaete) & 3.9 \\
\hline
\end{tabular}


[Type here]

\section{B.2 Biogeographic variations in the species composition of mudflat assemblages}
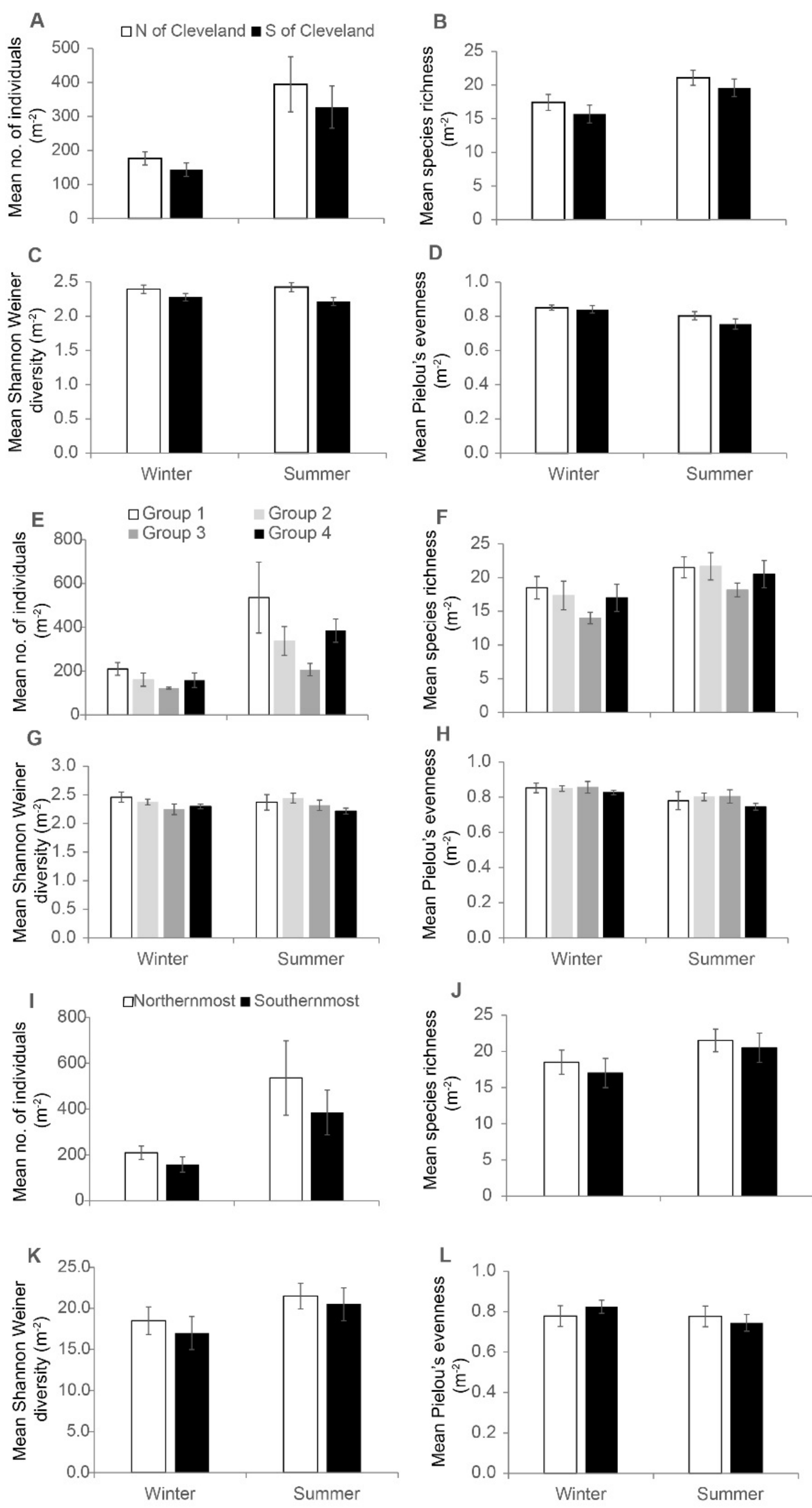

Fig. B.1. Mudflat macrofaunal assemblage $(n=24)$ mean $( \pm S E)$ density, species richness, Shannon Weiner diversity and Pielou's evenness across varying biogeographic conditions in SE Queensland, Australia in winter 2016 and summer 2017. Data are grouped: (A)-(D) north and south of Cleveland; (E)-(I) into four subgroups from north to south by latitude (group 1: mudflat 1-6; group 2: mudflats 712; group 3: mudflats 13-18; group 4: mudflats 19-24 most southern sites (Fig. 1); and (J)-(L) the northernmost and southernmost six sites. 
[Type here]

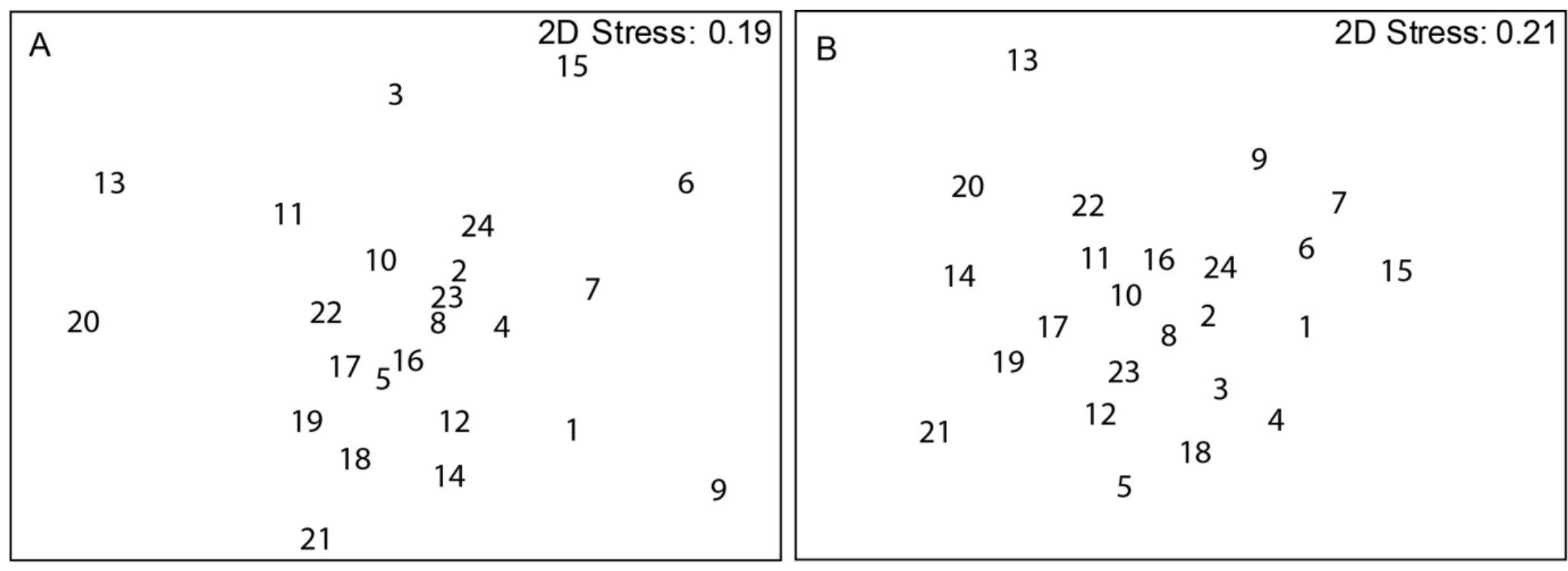

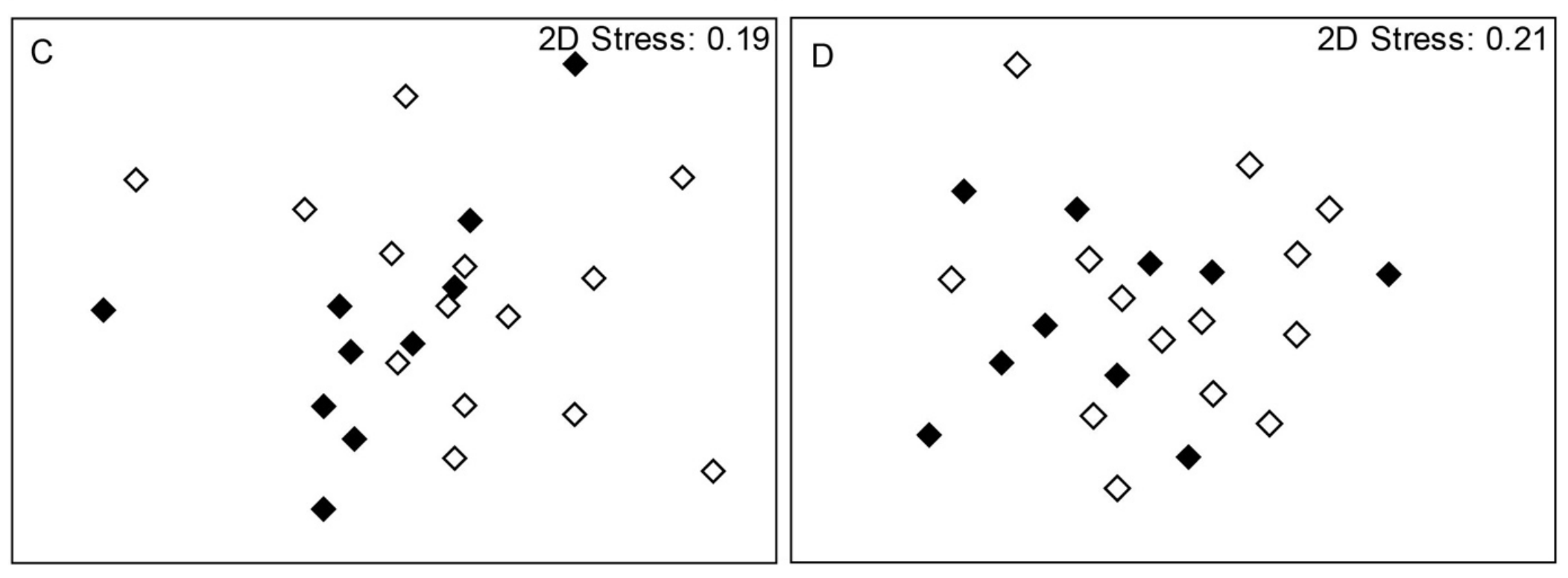

$\diamond$ North of Cleveland $\diamond$ South of Cleveland

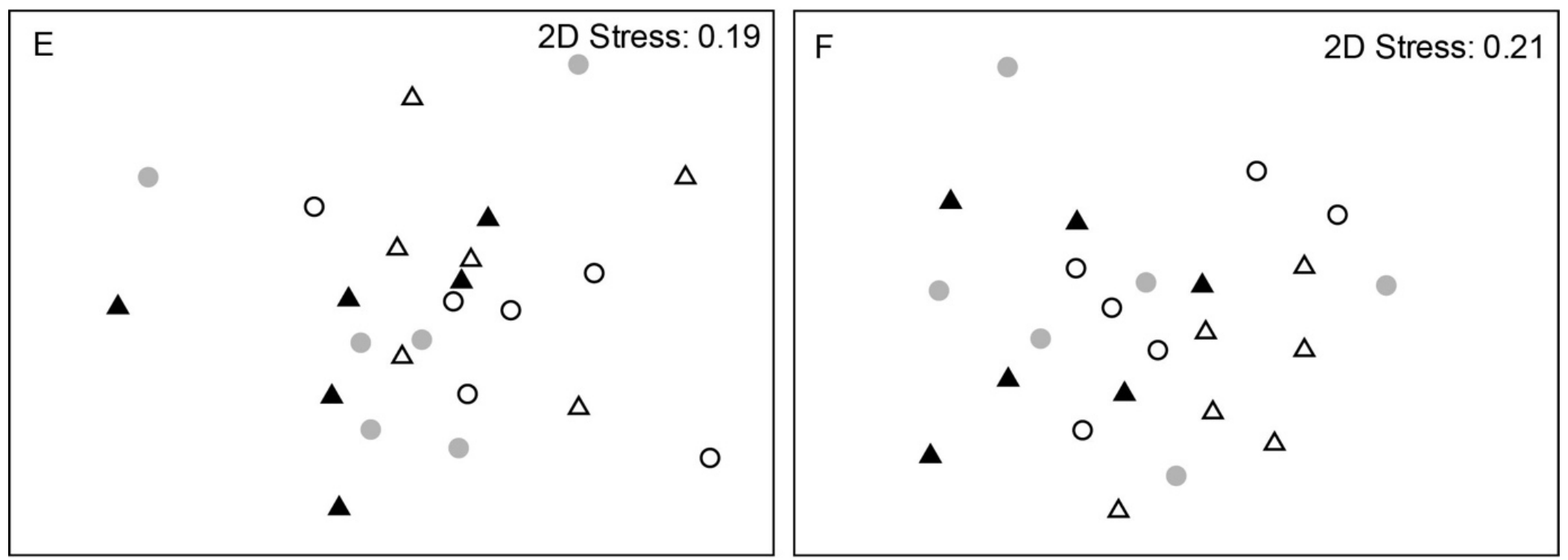

$\Delta$ 1-6 mudflats 0 7-12 mudflats $\bigcirc 13-18$ mudflats $\Delta$ 19-24 mudflats

Fig. B. $2 \mathrm{nMDS}$ ordination of the Bray-Curtis similarity of the macrofaunal assemblage composition (log $(X+1)$ transformed) in 24 mudflats in SE Queensland, Australia. The taxonomic composition of the mudflat assemblages (A) with site numbers for summer, (B) with site numbers for winter, (C) north and south of Cleveland in winter, and (D) summer; (E) between four groups of sites from north (sites 1-6) to south (sites 19-24) in winter, and (F) summer. 
[Type here]

Table B.2. Kruskal-Wallis comparisons of the median number of individuals per $\mathrm{m}^{2}$, species richness, Shannon Weiner diversity and Pielou's evenness of the macrofaunal assemblages from 24 mudflats in SE Queensland in winter 2016 and summer 2017. Three biogeographic comparisons are included (Fig. 1): (i) sites to the north and south of Cleveland, (ii) the 24 sites divided into 4 equal-sized groups proceeding from north to south, and (iii) the northernmost and southernmost six sites. ${ }^{*}$ Indicates a significant difference.

\begin{tabular}{lcccccc}
\hline Metric $\left(\mathrm{m}^{-2}\right)$ & \multicolumn{3}{c}{ Winter 2016 } & \multicolumn{3}{c}{ Summer 2017 } \\
& $\mathrm{\chi}^{2}$ & $\mathrm{df}, \mathrm{n}$ & $\mathrm{p}$ & $\chi^{2}$ & $\mathrm{df}, \mathrm{n}$ & $\mathrm{p}$ \\
\hline (i) North and south of Cleveland & & & & & \\
Total no. individuals & 0.992 & 1,24 & 0.319 & 0.014 & 1,24 & 0.907 \\
Species richness & 0.679 & 1,24 & 0.410 & 0.630 & 1,24 & 0.427 \\
Shannon Weiner & 2.143 & 1,24 & 0.143 & 5.488 & 1,24 & $0.019^{*}$ \\
$\begin{array}{l}\text { Pielou's evenness } \\
\text { (ii) Four equal sized groups }\end{array}$ & 0.003 & 1,24 & 0.953 & 1.895 & 1,24 & 0.169 \\
Total no. individuals & & & & & & \\
Species richness & 4.112 & 3,6 & 0.250 & 4.780 & 3,6 & 0.189 \\
Shannon Weiner & 2.934 & 3,6 & 0.402 & 2.914 & 3,6 & 0.405 \\
$\begin{array}{l}\text { Pielou's evenness } \\
\text { (iii) Northernmost and southernmost six sites }\end{array}$ & 3.713 & 3,6 & 0.294 & 3.527 & 3,6 & 0.317 \\
Total no. individuals & 1.641 & 1,6 & 0.200 & 0.641 & 1,6 & 0.423 \\
Species richness & 0.105 & 1,6 & 0.746 & 0.103 & 1,6 & 0.748 \\
Shannon Weiner & 0.410 & 1,6 & 0.522 & 1.641 & 1,6 & 0.200 \\
Pielou's evenness & 0.316 & 1,6 & 0.574 & 0.926 & 1,6 & 0.336 \\
\hline
\end{tabular}

Table B.3 The biogeographic ranges of the 50 taxa (summer and winter combined) found in the 24 mudflats sampled during this study, and their known global latitudinal ranges as documented from published databases (ALA, 2018; OBIS, 2018). (Australian documented latitudinal ranges in Australia are provided in the manuscript Table 3). These new records extended the ranges of 10 species (bold rows), and for these species the year (the latest date the shift could have begun), extent and direction of the expansion is provided. The 'typical' climatic zone of each species based on previous records is given using the tropical climatic zones defined as $23^{\circ} 27^{\prime} S$ (Dissanayake et al. (2018)), and the temperate climatic zone boundary $\left(32.4^{\circ} 00^{\prime} \mathrm{S}\right)$ was based on the southward boundary of MoretonTweed marine ecoregion described by Spalding et al. (2007) and the convergence of the Australian East Coast Current and westward Tasman Front (Cetina-Heredia et al., 2014). Abbreviations: Trop = Tropical, Temp = Temperate, $\mathrm{N}=$ number of sites/records.

\begin{tabular}{|c|c|c|c|c|c|c|c|c|c|c|}
\hline \multirow[t]{2}{*}{ Species } & \multirow[t]{2}{*}{$\begin{array}{l}\text { Sp. } \\
\text { zone }\end{array}$} & \multicolumn{3}{|c|}{$\begin{array}{l}\text { Max. documented latitudinal } \\
\text { range }\left(^{\circ}\right) \text { of taxa }\end{array}$} & \multicolumn{4}{|c|}{$\begin{array}{c}\text { Latitudinal range of taxa at } 24 \\
\text { mudflats sampled }\end{array}$} & \multirow{2}{*}{$\begin{array}{l}\text { Dist. } \\
\text { moved } \\
(\mathrm{km})\end{array}$} & \multirow{2}{*}{$\begin{array}{c}\text { Rate } \\
(\mathrm{km} \\
\left.\text { decade }^{-1}\right)\end{array}$} \\
\hline & & Year & North & South & $\mathbf{N}$ & North & South & $\mathbf{N}$ & & \\
\hline Acetes sibogae ${ }^{2}$ & Temp & & -5.0000 & -36.2070 & 174 & -27.3436 & -28.1069 & 12 & & \\
\hline Aglaophamus australiensis & Temp & & -17.0330 & -43.0330 & 1093 & -27.1464 & -28.1069 & 23 & & \\
\hline Alpheus richardsoni² & Temp & & -9.5000 & -41.4660 & 143 & -27.1747 & -28.1069 & 9 & & \\
\hline Armandia intermedia ${ }^{2}$ & Temp & & 27.2355 & -38.8500 & 285 & -27.1747 & -28.1069 & 16 & & \\
\hline Australonereis ehlersi & Temp & & -23.1830 & -42.2752 & 566 & -27.1464 & -28.1069 & 12 & & \\
\hline Australoplax tridentata & Trop & & -10.7333 & -36.2078 & 83 & -27.1956 & -28.1069 & 14 & & \\
\hline Barantolla lepte & Temp & & -22.3830 & -38.8500 & 791 & -27.1747 & -27.8222 & 18 & & \\
\hline Bulla vernicosa ${ }^{2}$ & Trop & & 26.5000 & -34.7500 & 430 & -27.2597 & -28.1069 & 3 & & \\
\hline Chaenostoma punctulatum & Temp & & -10.7160 & -36.0653 & 58 & -27.1464 & -28.1069 & 14 & & \\
\hline Cirriformia tentaculata ${ }^{2}$ & Temp & & 60.4103 & -42.8800 & 82 & -27.1747 & -27.6436 & 6 & & \\
\hline Clorida depressa ${ }^{2}$ & Trop & 1998 & -4.8172 & -27.6667 & 59 & -27.1956 & -27.7178 & 5 & $6 S$ & 3 \\
\hline Conuber sordidum ${ }^{2}$ & All & & -1.5000 & -43.1179 & 544 & -27.1464 & -28.1069 & 21 & & \\
\hline
\end{tabular}


[Type here]

\begin{tabular}{|c|c|c|c|c|c|c|c|c|c|c|}
\hline Elphidium discoidale ${ }^{1,2}$ & Trop & & 29.3800 & -24.6814 & 48 & -27.1747 & -28.1069 & 7 & & \\
\hline Eurysyllis tuberculata ${ }^{2,4}$ & Trop & & 60.4102 & -34.7500 & 31 & -27.1747 & -27.7178 & 6 & & \\
\hline Gelasimus vomeris ${ }^{2}$ & Trop & & 11.6660 & -33.8083 & 145 & -27.2775 & -28.1069 & 10 & & \\
\hline Glycera americana ${ }^{2}$ & Temp & & 54.9781 & -41.1600 & 515 & -27.1956 & -27.8222 & 12 & & \\
\hline Haminoea fusca 4 & Trop & 1970 & -14.6700 & -25.2500 & 16 & -27.1747 & -28.1069 & 16 & $317 \mathrm{~S}$ & 68 \\
\hline Helograpsus haswellianus ${ }^{2}$ & Temp & & 34.6800 & -43.0300 & 207 & -27.3436 & -27.8222 & 10 & & \\
\hline Hiatula alba & Temp & & -21.4592 & -43.4630 & 69 & -27.1464 & -28.1069 & 18 & & \\
\hline Laternula anatina ${ }^{2,4}$ & Trop & 1996 & 35.3317 & -23.4160 & 103 & -27.1956 & -27.7053 & 5 & $477 \mathrm{~S}$ & 227 \\
\hline Leitoscoloplos bifurcatus & Temp & & -12.4330 & -42.3902 & 489 & -27.1464 & -28.1069 & 12 & & \\
\hline Lingula anatina & Trop & & -21.6786 & -27.9667 & 47 & -27.2597 & -27.5158 & 2 & & \\
\hline Lumbrineris tetraura ${ }^{2}$ & Temp & & 60.4100 & -38.7300 & 716 & -27.1747 & -28.1069 & 12 & & \\
\hline Lutraria impar ${ }^{2}$ & Trop & & 21.6788 & -28.3803 & 24 & -27.1956 & -27.4764 & 4 & & \\
\hline Macrophthalmus setosus & Temp & & -22.3833 & -36.0612 & 133 & -27.1747 & -28.1069 & 21 & & \\
\hline Mactra maculata ${ }^{2,3}$ & Trop & 1949 & -9.9500 & -27.5830 & 61 & -27.1463 & -28.1069 & 17 & $58 \mathrm{~S}$ & 9 \\
\hline Magelona dakini & Temp & & -18.7330 & -41.1612 & 371 & -27.1464 & -28.1069 & 19 & & \\
\hline Marcia hiantina ${ }^{2}$ & Trop & 1982 & 22.6252 & -27.6167 & 250 & -27.1464 & -28.1069 & 16 & $54 \mathrm{~S}$ & 16 \\
\hline Marphysa mullawa & Temp & & -12.6660 & -36.8917 & 122 & -27.1747 & -28.1069 & 9 & & \\
\hline Metapenaeus endeavouri ${ }^{2}$ & Trop & 1961 & -9.3100 & -27.4167 & 2395 & -27.2775 & -28.1069 & 8 & $77 \mathrm{~s}$ & 14 \\
\hline Mictyris longicarpus ${ }^{2}$ & All & & 24.1792 & -38.4612 & 342 & -27.1464 & -28.1069 & 20 & & \\
\hline Myrianida australiensis & Temp & 2011 & -30.5409 & -30.5409 & 1 & -27.1747 & -27.7503 & 11 & $374 \mathrm{~N}$ & 623 \\
\hline Nassarius coronatus ${ }^{2}$ & Trop & & 28.9660 & -34.2544 & 299 & -27.2597 & -27.7503 & 4 & & \\
\hline Nematoda $^{2}$ & All & & 69.3539 & -41.7339 & 30516 & -27.1464 & -28.1069 & 20 & & \\
\hline Nemertea $^{2}$ & All & & 71.5508 & -75.0967 & 3202 & -27.1747 & -28.1069 & 13 & & \\
\hline Notomastus torquatus & Temp & & -23.8160 & -38.4889 & 493 & -27.1464 & -28.1069 & 21 & & \\
\hline Owenia australis & Temp & & -12.0880 & -38.9000 & 248 & -27.1464 & -28.1069 & 21 & & \\
\hline Paratapes undulatus ${ }^{2}$ & Trop & & 23.9850 & -36.9033 & 230 & -27.1956 & -27.5158 & 2 & & \\
\hline $\begin{array}{l}\text { Phyllodoce } \\
\text { novaehollandiae }\end{array}$ & Temp & & -19.8830 & -38.7661 & 108 & -27.1464 & -28.1069 & 16 & & \\
\hline Platynereis antipoda² & Temp & & 21.4100 & -43.4350 & 385 & -27.2775 & -27.7178 & 6 & & \\
\hline Prionospio queenslandica 4 & Trop & & -10.5861 & -35.7461 & 17 & -27.1463 & -27.7178 & 11 & & \\
\hline Pyrazus ebeninus & All & & -10.6830 & -42.9111 & 380 & -27.1464 & -28.1069 & 22 & & \\
\hline Recluzia johniiं & Trop & & -12.3500 & -34.0583 & 11 & -27.7178 & -27.7503 & 2 & & \\
\hline Stenothoe miersi & Temp & & -14.5719 & -37.8898 & 48 & -27.1747 & -28.1069 & 8 & & \\
\hline Sternaspis scutata $a^{2,4}$ & Trop & & 77.9983 & -70.5000 & 3177 & -27.3436 & -27.7503 & 7 & & \\
\hline Sthenelais boa ${ }^{2}$ & Temp & & 69.9475 & -34.0083 & 3971 & -27.5158 & -27.8222 & 4 & & \\
\hline Trypaea australiensis & Temp & & -12.8667 & -38.7000 & 651 & -27.395 & -28.1069 & 6 & & \\
\hline Tubuca polita ${ }^{2}$ & Trop & & -9.3830 & -30.8830 & 102 & -27.2775 & -27.2775 & 1 & & \\
\hline Uca longidigita & Trop & 1962 & -21.1333 & -27.5000 & 27 & -27.4222 & -27.7503 & 4 & $28 \mathrm{~S}$ & 5 \\
\hline Victoriopisa australiensis ${ }^{3}$ & Temp & 2007 & -27.9160 & -37.0963 & 186 & -27.1464 & -27.7503 & 11 & $86 \mathrm{~N}$ & 86 \\
\hline
\end{tabular}

${ }^{1}$ The range given is for $E$. discoidale, however this record could potentially be confounded as subspecies Elphidium discoidale var. multiloculum was described from Moreton Bay (-27.1108 to -27.6583) by Narayan and Pandolfi (2010). If this is variety is confirmed as a distinct taxon then the record in the present study may not represent a range shift for the species. ${ }^{2}$ The global range of the species differed from the Australian range. ${ }^{3}$ Taxa previously recorded only once within the study area. ${ }^{4}$ Taxa not previously recorded in the study area (and only once in greater SE Queensland).

\section{B.3. Biogeographic differences in macrofaunal trait composition}

Similar to species compositional patterns, the trait diversity measures did not differ significantly between each biogeographic gradient (Table B.4) of the SE Queensland subtropical mudflat assemblages 
[Type here]

Table B.4. Kruskal-Wallis comparisons of the median number of trait modality richness, Shannon Weiner diversity and Pielou's evenness for trait modalities of the macrofaunal assemblages found in mudflats from 24 sites in SE Queensland in the winter of 2016 and summer of 2017. Three comparisons are included (i) those sites to the north and south of Cleveland, (ii) the 24 sites divided into 4 groups (six sites each) proceeding from north to south, and (iii) the northernmost and southernmost six sites. ${ }^{*}$ Indicates a significant difference

\begin{tabular}{|c|c|c|c|c|c|c|}
\hline \multirow[t]{2}{*}{ Metric $\left(\mathrm{m}^{-2}\right)$} & \multicolumn{3}{|c|}{ Winter 2016} & \multicolumn{3}{|c|}{ Summer 2017} \\
\hline & $x^{2}$ & $\mathrm{df}, \mathrm{n}$ & $\mathrm{p}$ & $\chi^{2}$ & $\mathrm{df}, \mathrm{n}$ & $\mathrm{p}$ \\
\hline \multicolumn{7}{|c|}{ (i) North and south of Cleveland } \\
\hline Trait modality richness & 0.468 & 1,24 & 0.494 & 0.004 & 1,24 & 0.951 \\
\hline Shannon Weiner & 2.788 & 1,24 & 0.095 & 4.443 & 1,24 & $0.035^{*}$ \\
\hline \multicolumn{7}{|c|}{ (ii) Four equal sized groups } \\
\hline Trait modality richness & 1.379 & 3,6 & 0.711 & 3.729 & 3,6 & 0.292 \\
\hline Shannon Weiner & 3.980 & 3,6 & 0.264 & 3.800 & 3,6 & 0.284 \\
\hline Pielou's evenness & 2.256 & 3,6 & 0.521 & 2.993 & 3,6 & 0.393 \\
\hline \multicolumn{7}{|c|}{ (iii) Northernmost and southernmost six sites } \\
\hline Trait modality richness & 0.061 & 1,6 & 0.805 & 0.408 & 1,6 & 0.523 \\
\hline Shannon Weiner & 1.447 & 1,6 & 0.229 & 1.256 & 1,6 & 0.262 \\
\hline Pielou's evenness & 0.231 & 1,6 & 0.631 & 0.641 & 1,6 & 0.423 \\
\hline
\end{tabular}

\section{B.4. Trait modality profiles}

Table B.5. The trait modalities that contributed $>50 \%$ cumulative dissimilarity between the trait profiles of temperate species that occurred throughout SE Queensland and (i) tropical range shifters, (ii) tropical species that occurred throughout SE Queensland, (iii) tropical species that were absent from southernmost 6 sites. The significant differences $\left({ }^{*}\right)$ of the trait modalities between the paired groups identified by Mann-Whitney $U$ test are also represented.

\begin{tabular}{|c|c|c|c|}
\hline Trait modalities & \multicolumn{3}{|c|}{ Mann-Whitney $U$ test to compare the differences between the groups } \\
\hline Temperate taxa vs & Tropical range shifters & $\begin{array}{l}\text { Tropical sp. occurred } \\
\text { throughout SE Qld }\end{array}$ & $\begin{array}{l}\text { Tropical sp. that were } \\
\text { absent in SE Qld }\end{array}$ \\
\hline 10-30 mm body size & $Z=-0.445, p=0.657$ & $Z=-2.912, p=0.004^{*}$ & $Z=-0.149, p=0.882$ \\
\hline$>50$ mm body size & $Z=-0.176, p=0.861$ & $Z=-2.8276, p=0.005^{*}$ & $Z=-0.872, p=0.383$ \\
\hline Round shaped & $Z=-2.611, p=0.009^{*}$ & $Z=-0.922, p=0.357$ & $Z=-0.855, p=0.392$ \\
\hline Rectangular shaped & $Z=-1.237, p=0.216$ & $Z=-1.966, p=0.049^{*}$ & $Z=-2.238, p=0.025^{*}$ \\
\hline Vermiform shaped & $Z=-3.223, p=0.001^{*}$ & $Z=-2.451, p=0.014^{*}$ & $Z=-2.619, p=0.009^{*}$ \\
\hline No body armour & $Z=-2.524, p=0.012^{*}$ & $Z=-2.493, p=0.013^{*}$ & $Z=-3.117, p=0.002^{*}$ \\
\hline $\begin{array}{l}0.5-1 \mathrm{~mm} \text { body } \\
\text { armour }\end{array}$ & $Z=-0.832, p=0.405$ & $Z=-1.436, p=0.151$ & $Z=-3.441, p=0.001^{*}$ \\
\hline Temporary attached & $Z=0.000, p=1.000$ & $Z=0.000, p=1.000$ & $Z=-3.310, p=0.001^{*}$ \\
\hline Planktotrophic & $Z=-0.310, p=0.756$ & $Z=-0.990, p=0.322$ & $Z=-0.441, p=0.659$ \\
\hline Deposit feeder & $Z=-2.069, p=0.039^{*}$ & $Z=-0.219, p=0.827$ & $Z=-1.193, p=0.233$ \\
\hline Suspension feeder & $Z=-2.891, p=0.004^{*}$ & $Z=-0.131, p=0.896$ & $Z=-3.241, p=0.001^{*}$ \\
\hline Predator/scavenger & $Z=-1.406, p=0.160$ & $Z=-0.461, p=0.645$ & $Z=-1.698, p=0.090$ \\
\hline$>50 \mathrm{~mm}$ sed. depth & $Z=-0.731, p=0.465$ & $Z=-1.367, p=0.172$ & $Z=-1.468, p=0.142$ \\
\hline Sessile & $Z=-0.577, p=0.564$ & $Z=-0.655, p=0.513$ & $Z=-2.500, p=0.012^{*}$ \\
\hline Free movement & $Z=-0.622, p=0.534$ & $Z=-0.520, p=0.603$ & $Z=-1.370, p=0.171$ \\
\hline Surface modifier & $Z=-1.768, p=0.077$ & $Z=-0.085, p=0.932$ & $Z=-1.737, p=0.082$ \\
\hline
\end{tabular}


[Type here]

\begin{tabular}{llll}
\hline Biodiffusers & $Z=-1.346, p=0.178$ & $Z=-1.098, p=0.272$ & $Z=-1.869, p=0.062$ \\
$\begin{array}{l}\text { No habitat } \\
\text { modification }\end{array}$ & $Z=-1.258, p=0.209$ & $Z=-0.284, p=0.777$ & $Z=-0.555, p=0.579$ \\
\hline
\end{tabular}

\section{B.5. Simulations of species and traits composition and functional change}

The addition or removal of species from the baseline scenario changed the number of individuals within the unconstrained assemblage while the total abundance of individuals in the assemblage was capped for the constrained scenarios. The species composition (in both constrained and unconstrained analyses) differed significantly between the 5 scenarios in both seasons (Fig. B.3), with scenario 5 differing significantly from the remaining 4 scenarios in every case (ANOSIM p $<0.05$ in each case) (Table B.6).

The trait composition, in trials with the constrained total abundance, differed significantly between the 5 scenarios for winter (ANOSIM, global $R=0.209, p=0.002$, Fig. B.3A) and summer (ANOSIM, global $R=0.254, p=0.001$, Fig. B.3B). The pairwise ANOSIM results showed that the trait composition of scenario 5 differed significantly from the trait compositions of the remaining 4 scenarios, in line with the changed species composition (Table B.7-8).

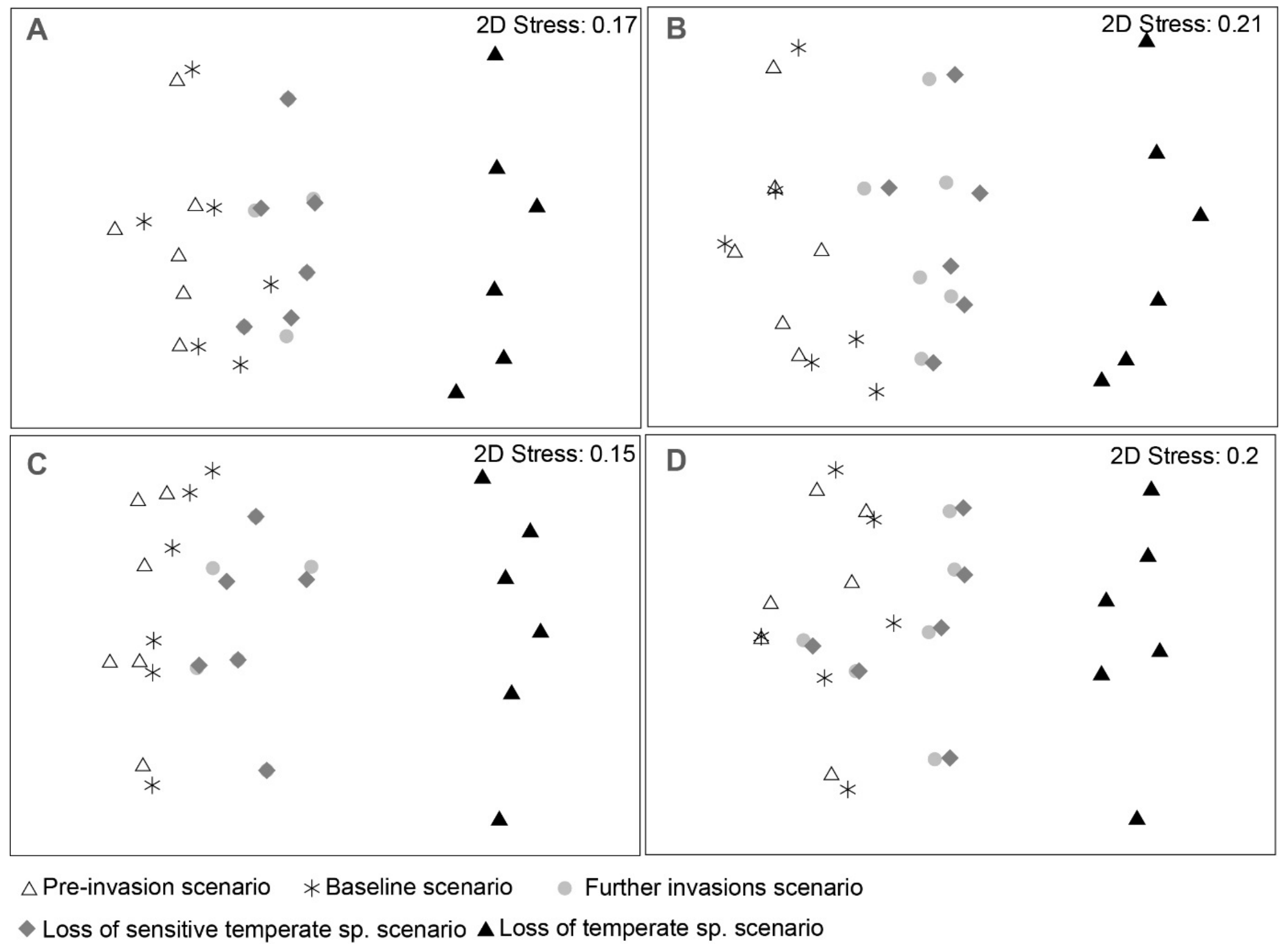


[Type here]

Fig. B.3. $\mathrm{nMDS}$ ordination of the Bray-Curtis similarity of the taxonomic composition $(\log (X+1)$ transformed) of the simulated mudflat macrofaunal assemblages observed in the six southernmost mudflats in SE Queensland. For the five scenarios based on unconstrained density (A) in winter 2016 and (B) in summer 2017; species composition (constrained density) (C) in winter 2016 and (D) in summer 2017.

Table B.6. Comparisons of the simulated macrofaunal species composition in SE Queensland mudflats (unconstrained and constrained density; pairwise ANOSIM) and SIMPER dissimilarity between the five range shift scenarios for winter 2016 and summer 2017. Species that contributed $>5 \%$ to the dissimilarity between each of the scenarios is shown. Species that differed significantly between the two scenarios are indicated in ${ }^{(*)}$ sign. A. australiensis = Aglaophamus australiensis, B. lepte = Barantolla lepte, $\mathrm{H}$. alba = Hiatula alba, Li. anatina = Lingula anatine, Lu. impar = Lutraria impar, $\mathrm{M}$. setosus = Macrophthalmus setosus, $M$. dakini = Magelona dakini, $N$. torquatus = Notomastus torquatus and $P$. ebeninus $=$ Pyrazus ebeninus.

\begin{tabular}{|c|c|c|c|}
\hline $\begin{array}{l}\text { Scenario } \\
\text { comparisons }\end{array}$ & ANOSIM statistics & $\begin{array}{l}\text { SIMPER } \\
\text { dissim. } \\
(\%)\end{array}$ & $\begin{array}{c}\text { Species that contributed }>5 \% \text { to SIMPER } \\
\text { dissimilarity }\end{array}$ \\
\hline \multicolumn{4}{|c|}{ Winter density (unconstrained) } \\
\hline $5 \& 1$ & $R=0.906, p=0.002^{*}$ & 83.01 & A. australiensis, B. lepte, M. dakini, N. torquatus \\
\hline $5 \& 2$ & $R=0.983, p=0.002^{*}$ & 87.54 & $\begin{array}{l}\text { A. australiensis, B. lepte, M. dakini, N. torquatus, } \\
\text { H. alba, M. setosus }\end{array}$ \\
\hline $5 \& 3$ & $R=0.785, p=0.002^{*}$ & 69.44 & $\begin{array}{l}\text { A. australiensis, B. lepte, M. dakini, N. torquatus, } \\
\text { H. alba, M. setosus }\end{array}$ \\
\hline $5 \& 4$ & $\begin{array}{l}R=0.783 \\
p=0.002^{*}\end{array}$ & 68.84 & $\begin{array}{l}\text { A. australiensis, B. lepte, M. dakini, N. torquatus, } \\
\text { H. alba, M. setosus }\end{array}$ \\
\hline \multicolumn{4}{|c|}{ Summer density (unconstrained) } \\
\hline $1 \& 4$ & $R=0.250, p=0.019^{*}$ & 49.20 & Lu. impar, H. alba \\
\hline $2 \& 3$ & $R=0.250, p=0.032^{*}$ & 47.00 & Lu. impar, H. alba \\
\hline $2 \& 4$ & $R=0.309, p=0.009^{*}$ & 49.66 & Lu. impar, H. alba \\
\hline $5 \& 1$ & $R=0.870, p=0.002^{*}$ & 78.48 & A. australiensis, M. dakini, Lu. impar, N. torquatus \\
\hline $5 \& 2$ & $\mathrm{R}=0.993, \mathrm{p}=0.002^{*}$ & 81.53 & $\begin{array}{l}\text { A. australiensis, M. dakini, Lu. impar, N. } \\
\text { torquatus, B. lepte }\end{array}$ \\
\hline $5 \& 3$ & $R=0.700, p=0.002^{*}$ & 63.66 & A. australiensis, M. dakini, N. torquatus, B. lepte \\
\hline $5 \& 4$ & $R=0.650, p=0.002^{*}$ & 61.90 & $\begin{array}{l}\text { A. australiensis, M. dakini, N. torquatus, B. lepte, } \\
\text { M. setosus }\end{array}$ \\
\hline \multicolumn{4}{|c|}{ Winter density (constrained) } \\
\hline $5 \& 1$ & $R=0.970, p=0.002^{*}$ & 80.92 & Lu. impar, A. australiensis \\
\hline $5 \& 2$ & $R=0.998, p=0.002^{*}$ & 83.77 & Lu. impar, A. australiensis \\
\hline $5 \& 3$ & $\mathrm{R}=0.872, \mathrm{p}=0.002^{*}$ & 68.37 & A. australiensis, M. dakini \\
\hline $5 \& 4$ & $R=0.859, p=0.002^{*}$ & 66.90 & A. australiensis, M. dakini \\
\hline \multicolumn{4}{|c|}{ Summer density (constrained) } \\
\hline $5 \& 1$ & $\mathrm{R}=0.917, \mathrm{p}=0.002^{*}$ & 77.60 & $\begin{array}{l}\text { A. australiensis*, B. lepte, Lu. impar, M. dakini, Li. } \\
\text { anatina }\end{array}$ \\
\hline $5 \& 2$ & $R=1.000, p=0.002^{*}$ & 80.78 & $\begin{array}{l}\text { A. australiensis, B. lepte, Lu. impar, M. dakini, Li. } \\
\text { anatina }\end{array}$ \\
\hline $5 \& 3$ & $R=0.783, p=0.002^{*}$ & 67.18 & A. australiensis, B. lepte, Lu. impar, M. dakini \\
\hline $5 \& 4$ & $\begin{array}{l}R=0.752 \\
p=0.002^{*}\end{array}$ & 66.56 & A. australiensis, B. lepte, Lu. impar, M. dakini \\
\hline
\end{tabular}




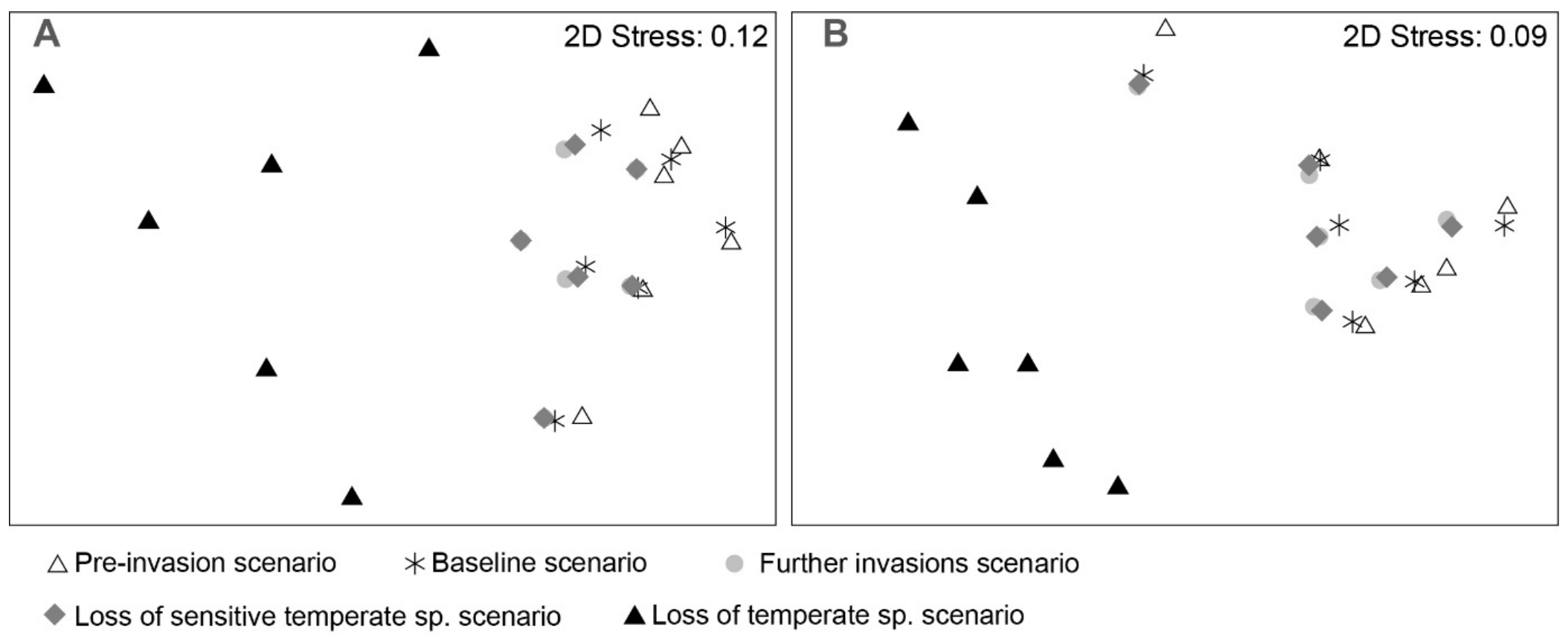

Fig. B.4. nMDS ordination of the Bray-Curtis similarity of the trait composition (density constrained) simulated mudflat macrofaunal assemblages observed in the SE Queensland southernmost 6 mudflats (A) in winter 2016 and (B) in summer 2017.

Table B.7. Comparisons of the simulated macrofaunal trait composition of SE Queensland southernmost 6 mudflats (density unconstrained and constrained; pairwise ANOSIM) and SIMPER dissimilarity between the five range shift scenarios for winter 2016 and summer 2017. Significant differences are indicated in (*) sign.

\begin{tabular}{lcc}
\hline Scenario comparisons & ANOSIM results & $\begin{array}{c}\text { Average SIMPER } \\
\text { dissimilarity (\%) }\end{array}$ \\
\hline Winter density unconstrained & \\
$5 \& 1$ & $R=0.572, p=0.009^{*}$ & 58.74 \\
$5 \& 2$ & $R=0.580, p=0.009^{*}$ & 57.91 \\
$5 \& 3$ & $R=0.578, p=0.006^{*}$ & 57.97 \\
$5 \& 4$ & $R=0.569, p=0.009^{*}$ & 57.75 \\
Summer density unconstrained & \\
$5 \& 1$ & $R=0.726, p=0.002^{*}$ & 67.27 \\
$5 \& 2$ & $R=0.733, P=0.002^{*}$ & 66.86 \\
$5 \& 3$ & $R=0.707, p=0.002^{*}$ & 66.45 \\
$5 \& 4$ & $R=0.700, p=0.002^{*}$ & 66.04 \\
Winter density constrained & \\
$5 \& 1$ & $R=0.765, p=0.002^{*}$ & 29.92 \\
$5 \& 2$ & $R=0.815, p=0.002^{*}$ & 31.74 \\
$5 \& 3$ & $R=0.646, p=0.002^{*}$ & 27.66 \\
$5 \& 4$ & $R=0.659, p=0.002^{*}$ & 27.92 \\
Summer density constrained & \\
$5 \& 1$ & $R=0.880, p=0.002^{*}$ & 36.98 \\
$5 \& 2$ & $R=0.946, p=0.002^{*}$ & 39.61 \\
$5 \& 3$ & $R=0.765, p=0.002^{*}$ & 33.62 \\
$5 \& 4$ & $R=0.776, p=0.002^{*}$ & 34.19 \\
\hline
\end{tabular}


[Type here]
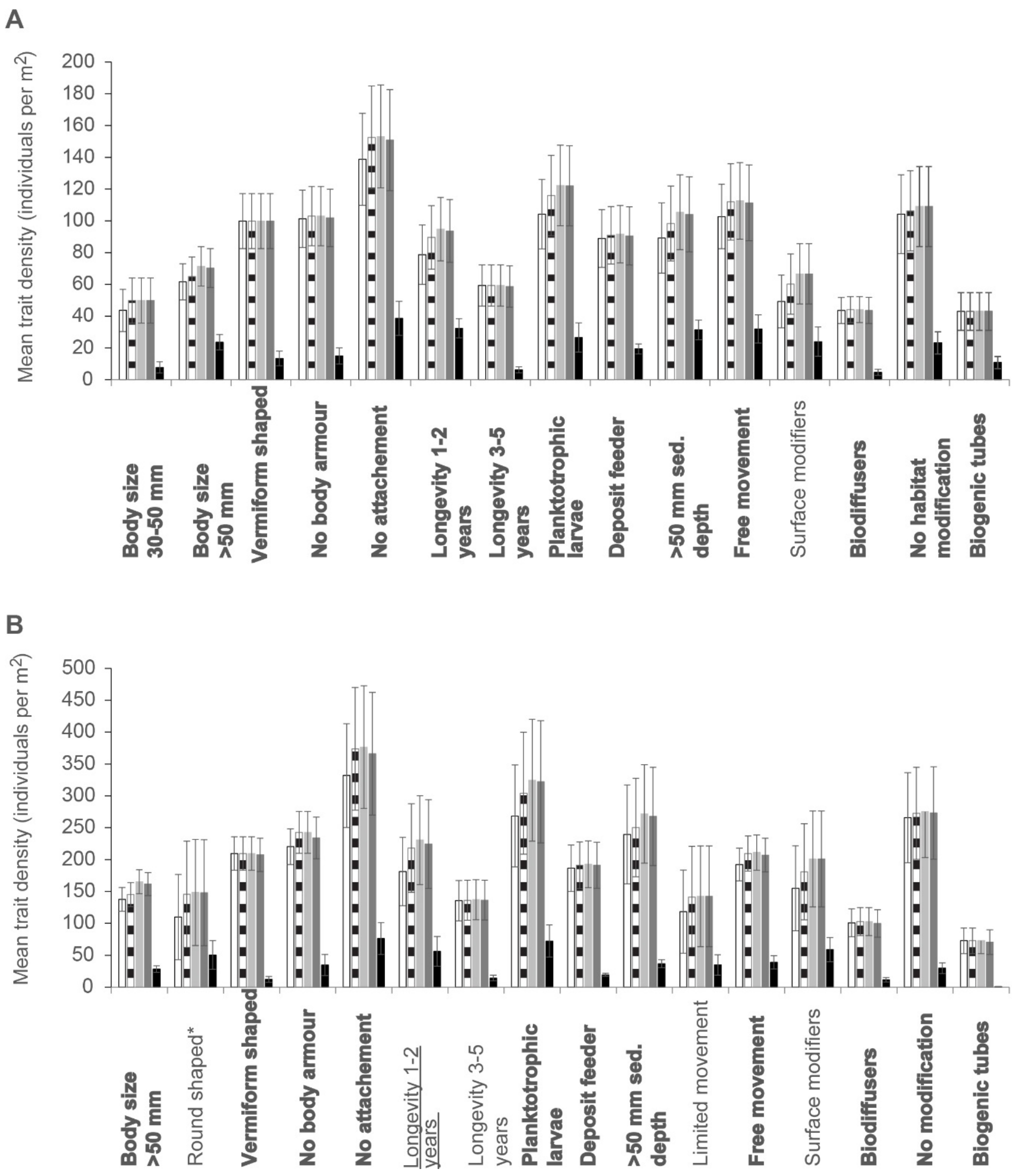
[Type here]
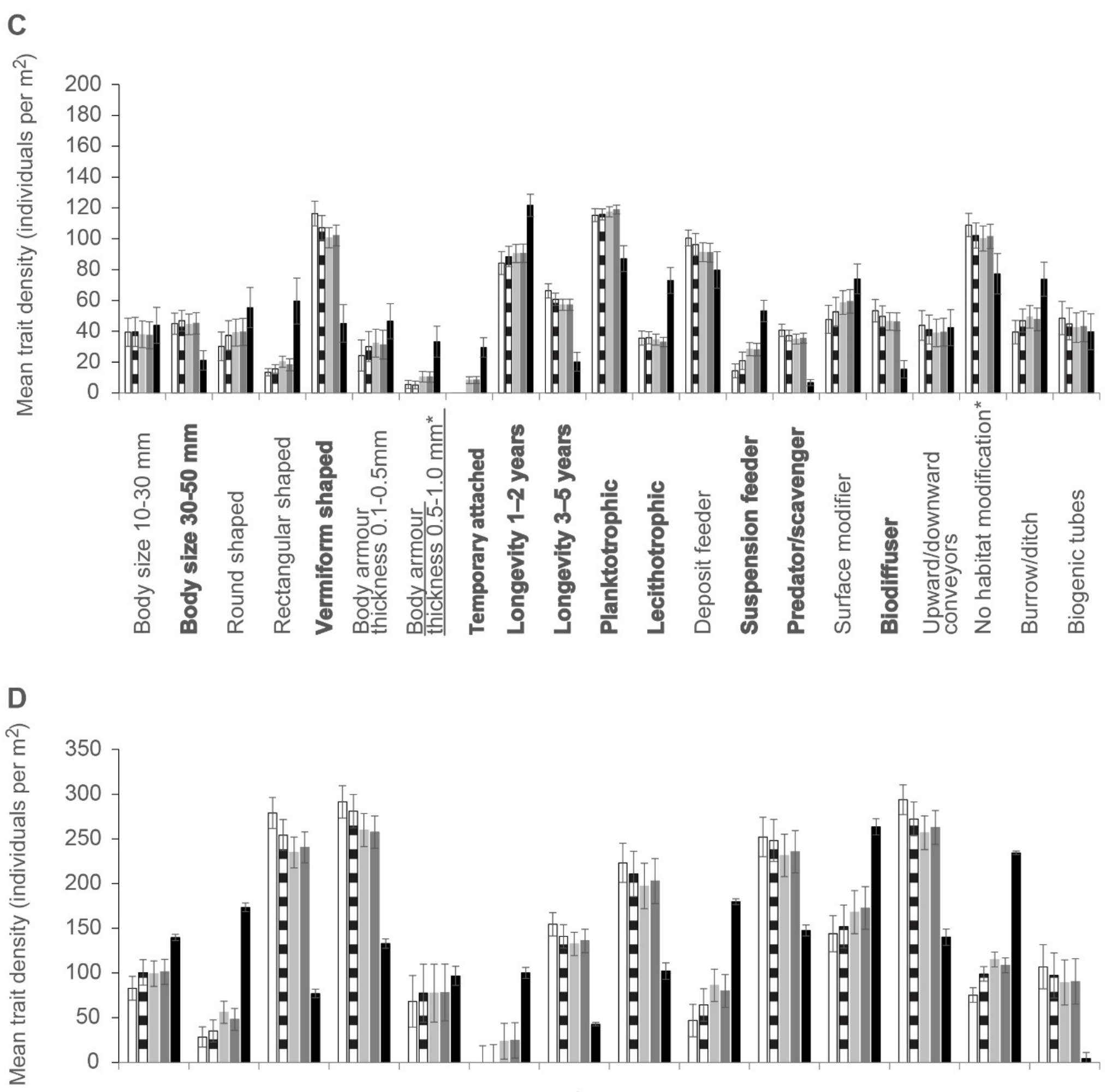

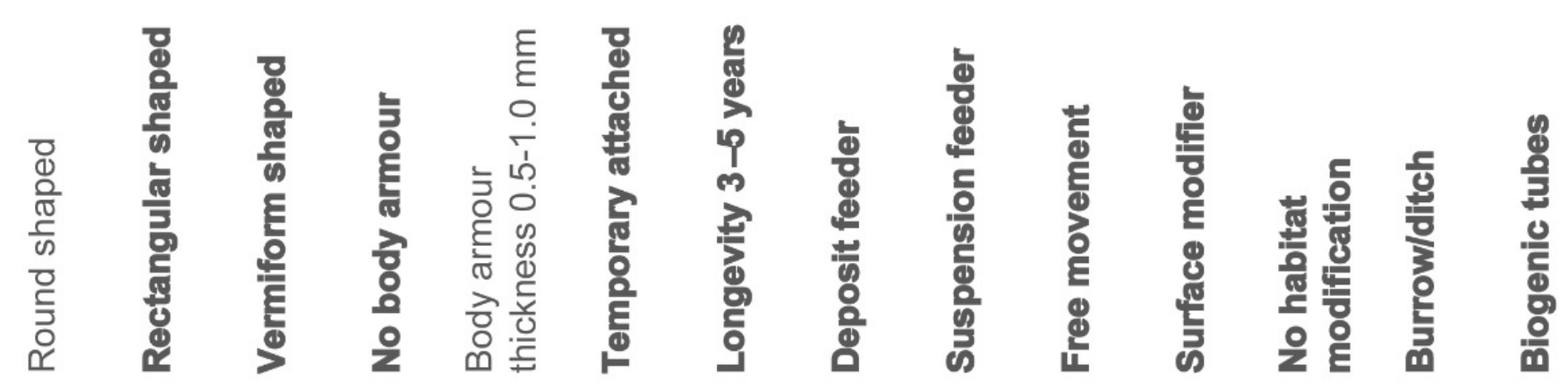

$\square$ Pre-invasion scenario $\square$ Baseline scenario $\quad$ Further invasion scenario
$\square$ Loss of sensitive temperate sp. scenario $\quad$ Loss of all temperate sp. scenaro

Fig B.5. The trait modalities (mean $\pm \mathrm{SE}$ ) that contributed to $>70 \%$ cumulative dissimilarity (SIMPER analysis) between the pairwise unconstrained trait compositional scenario groups in SE Queensland southernmost 6 mudflats (A) winter 2016 and (B) summer 2017, and constrained trait compositional scenario groups (C) winter 2016 and (D) summer 2017. The trait modalities in bold indicate that the trait composition of scenario 5 differed significantly $(p<0.05)$ from the remaining 4 scenarios, and the underlined trait modalities indicate that 2 scenarios have differed significantly from scenario 5 (Table B.8-9). 
[Type here]

Table B.8 Results of T-test to compare means abundances of trait modalities that contributed to the $70 \%$ of the dissimilarity between the five biogeographic range shift scenarios for mudflat macrofaunal assemblages in winter in SE Queensland. Results from both unconstrained and constrained macroinvertebrate density in winter 2016. Degrees of freedom=10. The biological traits that showed significant differences between the pairs are indicated in * sign

\begin{tabular}{|c|c|c|c|c|c|c|c|c|}
\hline \multirow{2}{*}{$\begin{array}{l}\text { Trait modalities } \\
\text { (for winter) }\end{array}$} & \multicolumn{4}{|c|}{ Scenario comparisons (unconstrained density) } & \multicolumn{4}{|c|}{ Scenario comparisons (constrained density) } \\
\hline & $1 \& 5$ & $2 \& 5$ & $3 \& 5$ & $4 \& 5$ & $1 \& 5$ & $2 \& 5$ & $3 \& 5$ & $4 \& 5$ \\
\hline $\begin{array}{l}\text { Body size } 30-50 \\
\mathrm{~mm}\end{array}$ & $\begin{aligned} t & =2.889 \\
p & =0.016^{*}\end{aligned}$ & & $\begin{aligned} t & =2.889 \\
p & =0.016^{*}\end{aligned}$ & $\begin{aligned} t & =2.889 \\
p & =0.016^{*}\end{aligned}$ & $\begin{aligned} \mathrm{t} & =2.800 \\
\mathrm{p} & =0.019^{*}\end{aligned}$ & & $\begin{aligned} t & =2.533 \\
p & =0.030^{*}\end{aligned}$ & $\begin{aligned} t & =2.580 \\
p & =0.027^{*}\end{aligned}$ \\
\hline Body size $>50 \mathrm{~mm}$ & $\begin{aligned} t & =3.116 \\
p & =0.011^{*}\end{aligned}$ & $\begin{aligned} t & =3.059 \\
p & =0.012^{*}\end{aligned}$ & $\begin{aligned} \mathrm{t} & =3.116 \\
\mathrm{p} & =0.011^{*}\end{aligned}$ & $\begin{aligned} t & =3.548 \\
p & =0.005^{*}\end{aligned}$ & & & & \\
\hline Rectangular shaped & & & & & $\begin{aligned} t & =-2.893 \\
p & =0.016^{*}\end{aligned}$ & $\begin{aligned} \mathrm{t} & =-3.049 \\
\mathrm{p} & =0.012^{*}\end{aligned}$ & $\begin{aligned} t & =-2.558 \\
p & =0.028^{*}\end{aligned}$ & $\begin{aligned} t & =-2.669 \\
p & =0.024^{*}\end{aligned}$ \\
\hline Round shaped & & & & & $\begin{array}{l}t=-1.117 \\
p=0.290\end{array}$ & $\begin{array}{l}t=-1.567 \\
p=0.148\end{array}$ & $\begin{array}{l}t=-1.030 \\
p=0.327\end{array}$ & $\begin{array}{l}t=-1.004 \\
p=0.339\end{array}$ \\
\hline Vermiform shaped & $\begin{aligned} \mathrm{t} & =4.819 \\
\mathrm{p} & =0.001^{*}\end{aligned}$ & $\begin{aligned} \mathrm{t} & =4.819 \\
\mathrm{p} & =0.001^{*}\end{aligned}$ & $\begin{aligned} \mathrm{t} & =4.819 \\
\mathrm{p} & =0.001^{*}\end{aligned}$ & $\begin{aligned} \mathrm{t} & =4.819 \\
\mathrm{p} & =0.001^{*}\end{aligned}$ & $\begin{aligned} \mathrm{t} & =4.294 \\
\mathrm{p} & =0.002^{*}\end{aligned}$ & $\begin{aligned} \mathrm{t} & =4.895 \\
\mathrm{p} & =0.001^{*}\end{aligned}$ & $\begin{aligned} \mathrm{t} & =4.021 \\
\mathrm{p} & =0.002^{*}\end{aligned}$ & $\begin{aligned} t & =4.099 p \\
& =0.002^{*}\end{aligned}$ \\
\hline No body armour & $\begin{aligned} t & =4.545 \\
p & =0.001^{*}\end{aligned}$ & $\begin{aligned} t & =4.602 \\
p & =0.001^{*}\end{aligned}$ & $\begin{aligned} t & =4.545 \\
p & =0.001^{*}\end{aligned}$ & $\begin{aligned} t & =4.618 \\
p & =0.001^{*}\end{aligned}$ & & & & \\
\hline $0.1-0.5 \mathrm{~mm}$ body & & & & & $t=-1.095$ & $t=-1.095$ & $t=-0.979$ & $t=-1.036$ \\
\hline armour thickness & & & & & $p=0.299$ & $p=0.299$ & $p=0.350$ & $p=0.325$ \\
\hline $0.5-1.0 \mathrm{~mm}$ body & & & & & $t=-2.707$ & $t=-2.707$ & $t=2.147$ & $t=-2.151$ \\
\hline armour thickness & & & & & $p=0.022^{*}$ & $p=0.022^{*}$ & $p=0.057$ & $p=0.057$ \\
\hline No attachment & $\begin{aligned} \mathrm{t} & =3.345 \\
\mathrm{p} & =0.007^{*}\end{aligned}$ & $\begin{aligned} \mathrm{t} & =3.246 \\
\mathrm{p} & =0.009^{*}\end{aligned}$ & $\begin{aligned} \mathrm{t} & =3.364 \\
\mathrm{p} & =0.007^{*}\end{aligned}$ & $\begin{aligned} \mathrm{t} & =3.341 \\
\mathrm{p} & =0.007^{*}\end{aligned}$ & & & & \\
\hline $\begin{array}{l}\text { Temporary } \\
\text { attached }\end{array}$ & & & & & $\begin{array}{l}t=-4.721 \\
p=0.001 *\end{array}$ & $\begin{array}{l}\mathrm{t}=-4.729 \\
\mathrm{p}=0.001^{*}\end{array}$ & $\begin{array}{l}\mathrm{t}=-3.200 \\
\mathrm{p}=0.009^{*}\end{array}$ & $\begin{aligned} \mathrm{t} & =3.178 \\
\mathrm{p} & =0.010^{*}\end{aligned}$ \\
\hline Longevity $1-2$ years & $\begin{aligned} \mathrm{t} & =2.743 \\
\mathrm{p} & =0.021^{*}\end{aligned}$ & $\begin{aligned} \mathrm{t} & =2.364 \\
\mathrm{p} & =0.040^{*}\end{aligned}$ & $\begin{aligned} \mathrm{t} & =2.992 \\
\mathrm{p} & =0.014^{*}\end{aligned}$ & $\begin{array}{l}\mathrm{t}=2.965 \\
\mathrm{p}=0.014^{*}\end{array}$ & $\begin{array}{l}\mathrm{t}=-3.382 \\
\mathrm{p}=0.007^{*}\end{array}$ & $\begin{array}{l}\mathrm{t}=-3.382 \\
\mathrm{p}=0.007^{*}\end{array}$ & $\begin{array}{l}\mathrm{t}=-3.335 \\
\mathrm{p}=0.008^{*}\end{array}$ & $\begin{array}{l}t=-3.303 \\
p=0.008^{*}\end{array}$ \\
\hline Longevity $3-5$ years & $\begin{array}{l}t=4.033 \\
p=0.002^{*}\end{array}$ & $\begin{aligned} t & =4.033 \\
p & =0.002^{*}\end{aligned}$ & $\begin{array}{l}\mathrm{t}=4.033 \\
\mathrm{p}=0.002^{*}\end{array}$ & $\begin{aligned} t & =3.975 \\
p & =0.003^{*}\end{aligned}$ & $\begin{array}{l}t=5.664 \\
p<0.0001^{*}\end{array}$ & $\begin{array}{l}t=5.664 \\
p<0.0001^{*}\end{array}$ & $\begin{array}{l}t=5.271 \\
p<0.0001^{*}\end{array}$ & $\begin{array}{l}t=5.281 \\
p<0.0001^{*}\end{array}$ \\
\hline $\begin{array}{l}\text { Planktotrophic } \\
\text { larvae } \\
\text { Lecithotrophic } \\
\text { larvae }\end{array}$ & $\begin{aligned} t & =3.316 \\
p & =0.008^{*}\end{aligned}$ & $\begin{aligned} t & =3.363 \\
p & =0.009^{*}\end{aligned}$ & $\begin{aligned} t & =3.553 \\
p & =0.005^{*}\end{aligned}$ & $\begin{aligned} t & =3.555 \\
p & =0.005^{*}\end{aligned}$ & $\begin{aligned} t & =3.160 \\
p & =0.010^{*} \\
t & =-4.009 \\
p & =0.002^{*}\end{aligned}$ & $\begin{aligned} \mathrm{t} & =3.160 \\
\mathrm{p} & =0.010^{*} \\
\mathrm{t} & =-4.009 \\
\mathrm{p} & =0.002^{*}\end{aligned}$ & $\begin{aligned} \mathrm{t} & =3.391 \\
\mathrm{p} & =0.007^{*} \\
\mathrm{t} & =-4.211 \\
\mathrm{p} & =0.002^{*}\end{aligned}$ & $\begin{aligned} t & =3.609 \\
p & =0.005^{*} \\
t & =-4.479 \\
p & =0.001^{*}\end{aligned}$ \\
\hline Deposit feeder & $\begin{array}{l}t=3.896 \\
p=0.003^{*}\end{array}$ & $\begin{array}{l}t=3.769 \\
p=0.004^{*}\end{array}$ & $\begin{array}{l}t=3.932 \\
p=0.003^{*}\end{array}$ & $\begin{array}{l}t=3.840 \\
p=0.003^{*}\end{array}$ & $\begin{array}{l}t=1.192 \\
p=0.261\end{array}$ & $\begin{array}{l}t=1.192 \\
p=0.261\end{array}$ & $\begin{array}{l}t=0.864 \\
p=0.408\end{array}$ & $\begin{array}{l}t=0.846 \\
p=0.417\end{array}$ \\
\hline Suspension feeder & & & & & $\begin{aligned} t & =-3.603 \\
p & =0.005^{*}\end{aligned}$ & $\begin{aligned} t & =-3.603 \\
p & =0.005^{*}\end{aligned}$ & $\begin{aligned} t & =-3.057 \\
p & =0.012^{*}\end{aligned}$ & $\begin{aligned} \mathrm{t} & =-3.128 \\
\mathrm{p} & =0.011^{*}\end{aligned}$ \\
\hline Predator/scavenger & & & & & $\begin{array}{l}t=7.685 \\
p<0.0001^{*}\end{array}$ & $\begin{array}{c}t=7.685 \\
p<0.0001^{*}\end{array}$ & $\begin{array}{l}t=7.584 \\
p<0.0001^{*}\end{array}$ & $\begin{array}{l}t=7.571 \\
p<0.0001^{*}\end{array}$ \\
\hline$>50 \mathrm{~mm}$ sed. Depth & $\begin{array}{l}t=2.748 \\
p=0.021^{*}\end{array}$ & $\begin{array}{l}t=2.519 \\
p=0.030^{*}\end{array}$ & $\begin{array}{l}\mathrm{t}=3.038 \\
\mathrm{p}=0.013^{*}\end{array}$ & $\begin{array}{l}t=2.978 \\
p=0.014^{*}\end{array}$ & & & & \\
\hline Free movement & $\begin{array}{l}t=3.123 \\
p=0.011^{*}\end{array}$ & $\begin{aligned} t & =3.195 \\
p & =0.010^{*}\end{aligned}$ & $\begin{aligned} t & =3.149 \\
p & =0.010^{*}\end{aligned}$ & $\begin{aligned} t & =3.115 \\
p & =0.011^{*}\end{aligned}$ & & & & \\
\hline Surface modifiers & $\begin{array}{l}t=1.724 \\
p=0.115\end{array}$ & $\begin{array}{l}t=1.332 \\
p=0.212\end{array}$ & $\begin{array}{l}t=2.029 \\
p=0.070\end{array}$ & $\begin{array}{l}t=2.029 \\
p=0.070\end{array}$ & $\begin{array}{l}t=-1.597 \\
p=0.141\end{array}$ & $\begin{array}{l}t=-1.597 \\
p=0.141\end{array}$ & $\begin{array}{l}t=-1.254 \\
p=0.238\end{array}$ & $\begin{array}{l}t=-1.187 \\
p=0.263\end{array}$ \\
\hline Biodiffusers & $\begin{aligned} t & =4.675 \\
p & =0.001^{*}\end{aligned}$ & $\begin{aligned} t & =4.629 \\
p & =0.001^{*}\end{aligned}$ & $\begin{aligned} t & =4.675 \\
p & =0.001^{*}\end{aligned}$ & $\begin{aligned} t & =4.582 \\
p & =0.001^{*}\end{aligned}$ & $\begin{array}{l}t=3.840 \\
p=0.003\end{array}$ & $\begin{array}{l}t=3.840 \\
p=0.003\end{array}$ & $\begin{array}{l}t=3.840 \\
p=0.003\end{array}$ & $\begin{aligned} t & =3.834 p \\
& =0.003\end{aligned}$ \\
\hline $\begin{array}{l}\text { Upward/downward } \\
\text { conveyors }\end{array}$ & & & & & $\begin{array}{l}t=-0.079 \\
p=0.939\end{array}$ & $\begin{array}{l}t=-0.079 \\
p=0.939\end{array}$ & $\begin{array}{l}t=0.234 \\
p=0.820\end{array}$ & $\begin{array}{l}t=-0.197 \\
p=0.848\end{array}$ \\
\hline $\begin{array}{l}\text { No habitat } \\
\text { modification }\end{array}$ & $\begin{aligned} t & =3.177 \\
p & =0.010^{*}\end{aligned}$ & $\begin{array}{l}\mathrm{t}=3.157 \\
\mathrm{p}=0.010^{*}\end{array}$ & $\begin{aligned} \mathrm{t} & =3.278 \\
\mathrm{p} & =0.008^{*}\end{aligned}$ & $\begin{array}{l}\mathrm{t}=3.278 \\
\mathrm{p}=0.008^{*}\end{array}$ & $\begin{array}{l}t=1.599 \\
p=0.141\end{array}$ & $\begin{array}{l}t=1.599 \\
p=0.141\end{array}$ & $\begin{array}{l}t=1.478 \\
p=0.170\end{array}$ & $\begin{aligned} t & =1.576 p \\
& =0.146\end{aligned}$ \\
\hline Burrow/ditch & & & & & $\begin{array}{l}t=-2.004 \\
p=0.070\end{array}$ & $\begin{array}{l}t=-2.004 \\
p=0.070\end{array}$ & $\begin{array}{l}t=-1.835 \\
p=0.095\end{array}$ & $\begin{array}{l}t=-1.953 \\
p=0.079\end{array}$ \\
\hline Biogenic tubes & & $\begin{array}{l}t=2.586 \\
p=0.027^{*}\end{array}$ & & & $\begin{array}{l}t=0.335 \\
p=0.745\end{array}$ & $\begin{array}{l}t=0.335 \\
p=0.745\end{array}$ & $\begin{array}{l}t=0.177 \\
p=0.863\end{array}$ & $\begin{array}{l}t=0.227 p \\
=0.825\end{array}$ \\
\hline
\end{tabular}


[Type here]

Table B.9. Results of T-tests to compare mean abundance of trait modalities that contributed to $70 \%$ of the dissimilarity between the five biogeographic range shift scenarios for mudflat macrofaunal assemblages in summer in SE Queensland. Results from both unconstrained and constrained macroinvertebrate density in summer 2017. Degrees of freedom=10. The biological traits that showed significant differences between the pairs are indicated in * sign

\begin{tabular}{|c|c|c|c|c|c|c|c|c|}
\hline \multirow{2}{*}{$\begin{array}{l}\text { Trait modalities } \\
\text { (for summer) }\end{array}$} & \multicolumn{4}{|c|}{ Scenario comparisons (unconstrained density) } & \multicolumn{4}{|c|}{ Scenario comparisons (constrained density) } \\
\hline & $1 \& 5$ & $2 \& 5$ & $3 \& 5$ & $4 \& 5$ & $1 \& 5$ & $2 \& 5$ & $3 \& 5$ & $4 \& 5$ \\
\hline Body size $>50 \mathrm{~mm}$ & $\begin{array}{l}t=5.981 \\
p<0.0001^{*}\end{array}$ & $\begin{array}{l}t=3.059 \\
p=0.012^{*}\end{array}$ & $\begin{array}{l}t=7.018 \\
p<0.0001^{*}\end{array}$ & $\begin{array}{l}t=7.048 \\
p<0.0001^{*}\end{array}$ & & & & \\
\hline Rectangular shaped & & & & & $\begin{array}{l}t=-4.517 \\
p=0.001 *\end{array}$ & $\begin{array}{l}\mathrm{t}=-4.840 \\
\mathrm{p}=0.001^{*}\end{array}$ & $\begin{array}{l}t=-3.735 \\
p=0.004^{*}\end{array}$ & $\begin{array}{l}t=-4.034 \\
p=0.002^{*}\end{array}$ \\
\hline Round shaped & $\begin{array}{l}t=1.106 \\
p=0.296\end{array}$ & & & $\begin{array}{l}t=1.134 \\
p=0.283\end{array}$ & $\begin{array}{l}t=-0.675 \\
p=0.515\end{array}$ & $\begin{array}{l}t=-0.998 \\
p=0.346\end{array}$ & $\begin{array}{l}t=-0.707 \\
p=0.495\end{array}$ & $\begin{array}{l}t=-0.670 \\
p=0.518\end{array}$ \\
\hline Vermiform shaped & $\begin{array}{l}t=7.370 \\
p<0.0001^{*}\end{array}$ & $\begin{array}{l}\mathrm{t}=4.819 \\
\mathrm{p}=0.001\end{array}$ & $\begin{array}{l}t=7.370 \\
p<0.001^{*}\end{array}$ & $\begin{array}{l}t=7.409 \\
p<0.001^{*}\end{array}$ & $\begin{array}{l}t=4.197 \\
p=0.002^{*}\end{array}$ & $\begin{array}{l}t=4.607 \\
p=0.001^{*}\end{array}$ & $\begin{array}{l}t=4.069 \\
p=0.002^{*}\end{array}$ & $\begin{array}{l}t=4.116 \\
p=0.002^{*}\end{array}$ \\
\hline No body armour & $\begin{array}{l}t=5.663 \\
p<0.0001^{*}\end{array}$ & $\begin{array}{l}t=5.706 \\
p=0.001 *\end{array}$ & $\begin{array}{l}t=5.663 \\
p<0.0001^{*}\end{array}$ & $\begin{array}{l}t=5.434 \\
p<0.0001 *\end{array}$ & $\begin{array}{l}t=3.916 \\
p=0.003^{*}\end{array}$ & $\begin{array}{l}t=3.608 \\
p=0.005^{*}\end{array}$ & $\begin{array}{l}t=3.680 \\
p=0.004^{*}\end{array}$ & $\begin{array}{l}t=3.644 \\
p=0.005^{*}\end{array}$ \\
\hline $\begin{array}{l}0.1-0.5 \mathrm{~mm} \text { body } \\
\text { armour thickness }\end{array}$ & & & & & $\begin{array}{l}t=-0.451 \\
p=0.661\end{array}$ & & & \\
\hline $\begin{array}{l}0.5-1.0 \mathrm{~mm} \text { body } \\
\text { armour thickness }\end{array}$ & & & & & & $\begin{array}{l}t=-0.601 \\
p=0.561\end{array}$ & $\begin{array}{l}t=-0.464 \\
p=0.652\end{array}$ & $\begin{array}{l}t=-0.448 \\
p=0.664\end{array}$ \\
\hline No attachment & $\begin{array}{l}t=2.993 \\
p=0.013^{*}\end{array}$ & $\begin{array}{l}\mathrm{t}=3.002 \\
\mathrm{p}=0.013^{*}\end{array}$ & $\begin{array}{l}t=3.020 \\
p=0.013^{*}\end{array}$ & $\begin{array}{l}\mathrm{t}=2.919 \\
\mathrm{p}=0.015^{*}\end{array}$ & & & & \\
\hline $\begin{array}{l}\text { Temporary } \\
\text { attached }\end{array}$ & & & & & $\begin{array}{l}t=-5.151 \\
p<0.0001^{*}\end{array}$ & $\begin{array}{l}t=-5.151 \\
p<0.0001^{*}\end{array}$ & $\begin{array}{l}t=-3.826 \\
p=0.003^{*}\end{array}$ & $\begin{array}{l}t=-3.765 \\
p=0.004^{*}\end{array}$ \\
\hline Longevity $1-2$ years & $\begin{array}{l}t=2.206 \\
p=0.051\end{array}$ & $\begin{array}{l}t=2.364 \\
p=0.040^{*}\end{array}$ & $\begin{array}{l}t=2.376 \\
p=0.039^{*}\end{array}$ & $\begin{array}{l}t=2.291 \\
p=0.045^{*}\end{array}$ & $\begin{array}{l}t=-0.230 \\
p=0.823\end{array}$ & $\begin{array}{l}t=-0.533 \\
p=0.606\end{array}$ & $\begin{array}{l}t=-0.200 \\
p=0.846\end{array}$ & $\begin{array}{l}t=-0.214 \\
p=0.835\end{array}$ \\
\hline Longevity $3-5$ years & $\begin{array}{l}t=3.847 \\
p=0.003^{*}\end{array}$ & $\begin{array}{l}t=4.033 \\
p=0.002^{*}\end{array}$ & $\begin{array}{l}t=2.376 \\
p=0.039^{*}\end{array}$ & $\begin{array}{l}t=3.886 \\
p=0.003^{*}\end{array}$ & $\begin{array}{l}t=5.954 \\
p<0.0001^{*}\end{array}$ & $\begin{array}{l}t=6.314 \\
p<0.0001^{*}\end{array}$ & $\begin{array}{l}t=5.773 \\
p<0.0001 *\end{array}$ & $\begin{array}{l}t=5.985 \\
p<0.0001^{*}\end{array}$ \\
\hline $\begin{array}{l}\text { Planktotrophic } \\
\text { larvae }\end{array}$ & $\begin{array}{l}t=2.343 \\
p=0.040^{*}\end{array}$ & $\begin{array}{l}t=3.363 \\
p=0.009^{*}\end{array}$ & $\begin{array}{l}t=2.548 \\
p=0.029^{*}\end{array}$ & $\begin{array}{l}t=2.520 \\
p=0.030^{*}\end{array}$ & & & & \\
\hline Deposit feeder & $\begin{array}{l}t=4.675 \\
p=0.001^{*}\end{array}$ & $\begin{array}{l}t=3.769 \\
p=0.004^{*}\end{array}$ & $\begin{array}{l}t=4.717 \\
p=0.001^{*}\end{array}$ & $\begin{array}{l}t=4.743 \\
p=0.001^{*}\end{array}$ & $\begin{array}{l}t=4.124 \\
p=0.002^{*}\end{array}$ & $\begin{array}{l}t=5.384 \\
p<0.0001^{*}\end{array}$ & $\begin{array}{l}\mathrm{t}=3.882 \\
\mathrm{p}=0.003^{*}\end{array}$ & $\begin{array}{l}\mathrm{t}=3.952 \\
\mathrm{p}=0.003^{*}\end{array}$ \\
\hline Suspension feeder & & & & & $\begin{array}{l}t=-4.052 \\
p=0.002^{*}\end{array}$ & $\begin{array}{l}t=-5.109 \\
p<0.0001^{*}\end{array}$ & $\begin{array}{l}t=-3.677 \\
p=0.004^{*}\end{array}$ & $\begin{array}{l}t=-3.731 \\
p=0.004^{*}\end{array}$ \\
\hline$>50 \mathrm{~mm}$ sed. Depth & $\begin{array}{l}t=2.755 \\
p=0.020^{*}\end{array}$ & $\begin{array}{l}\mathrm{t}=2.519 \\
\mathrm{p}=0.030^{*}\end{array}$ & $\begin{array}{l}t=3.030 \\
p=0.013^{*}\end{array}$ & $\begin{array}{l}\mathrm{t}=2.988 \\
\mathrm{p}=0.014^{*}\end{array}$ & & & & \\
\hline Free movement & $\begin{array}{l}t=5.773 \\
p<0.0001^{*}\end{array}$ & $\begin{array}{l}\mathrm{t}=3.195 \\
\mathrm{p}=0.010^{*}\end{array}$ & $\begin{array}{l}t=5.826 \\
p<0.0001^{*}\end{array}$ & $\begin{array}{l}t=5.909 \\
p<0.0001^{*}\end{array}$ & $\begin{array}{l}\mathrm{t}=2.907 \\
\mathrm{p}=0.016^{*}\end{array}$ & $\begin{array}{l}t=3.032 \\
p=0.013^{*}\end{array}$ & $\begin{array}{l}\mathrm{t}=2.659 \\
\mathrm{p}=0.024^{*}\end{array}$ & $\begin{array}{l}\mathrm{t}=2.709 \\
\mathrm{p}=0.022^{*}\end{array}$ \\
\hline Limited movement & $\begin{array}{l}t=1.318 \\
p=0.217\end{array}$ & & $\begin{array}{l}t=1.132 \\
p=0.213\end{array}$ & $\begin{array}{l}t=1.132 \\
p=0.213\end{array}$ & & & & \\
\hline Surface modifiers & $\begin{array}{l}t=1.572 \\
p=0.147\end{array}$ & $\begin{array}{l}t=1.332 \\
p=0.212\end{array}$ & $\begin{array}{l}t=1.833 \\
p=0.097\end{array}$ & $\begin{array}{l}t=1.833 \\
p=0.097\end{array}$ & $\begin{array}{l}t=-2.752 \\
p=0.020^{*}\end{array}$ & $\begin{array}{l}t=-2.826 \\
p=0.018^{*}\end{array}$ & $\begin{array}{l}t=-2.574 \\
p=0.028^{*}\end{array}$ & $\begin{array}{l}t=-2.464 \\
p=0.033^{*}\end{array}$ \\
\hline Biodiffusers & & $\begin{array}{l}\mathrm{t}=4.629 \\
\mathrm{p}=0.001^{*}\end{array}$ & $\begin{array}{l}\mathrm{t}=4.112 \\
\mathrm{p}=0.002^{*}\end{array}$ & $\begin{array}{l}\mathrm{t}=4.041 \\
\mathrm{p}=0.002^{*}\end{array}$ & & & & \\
\hline $\begin{array}{l}\text { No habitat } \\
\text { modification } \\
\text { Burrow/ditch }\end{array}$ & $\begin{array}{l}t=3.343 \\
p=0.007^{*}\end{array}$ & $\begin{array}{l}t=3.157 \\
p=0.010^{*}\end{array}$ & $\begin{array}{l}\mathrm{t}=3.380 \\
\mathrm{p}=0.007^{*}\end{array}$ & $\begin{array}{l}\mathrm{t}=3.343 \\
\mathrm{p}=0.007^{*}\end{array}$ & $\begin{array}{l}t=5.088 \\
p<0.0001^{*} \\
t=-5.652 \\
p<0.0001^{*}\end{array}$ & $\begin{array}{l}t=5.998 \\
p<0.0001^{*} \\
t=-6.520 \\
p<0.0001^{*}\end{array}$ & $\begin{array}{l}t=4.438 \\
p=0.001^{*} \\
t=-4.936 \\
p=0.001^{*}\end{array}$ & $\begin{array}{l}t=4.632 \\
p=0.001^{*} \\
t=-5.181 \\
p<0.0001^{*}\end{array}$ \\
\hline Biogenic tubes & & $\begin{array}{l}t=2.586 \\
p=0.027^{*}\end{array}$ & & & $\begin{array}{l}t=3.126 \\
p=0.011^{*}\end{array}$ & $\begin{array}{l}t=3.122 \\
p=0.011^{*}\end{array}$ & $\begin{array}{l}\mathrm{t}=3.198 \\
\mathrm{p}=0.010^{*}\end{array}$ & $\begin{array}{l}t=3.160 \\
p=0.010^{*}\end{array}$ \\
\hline
\end{tabular}




\section{B.5.1 Mudflat ecological functioning past, present and future}

For model A (constrained density), nutrient cycling (ANOVA, winter: $F=0.294, p=0.879$; summer: $F$ $=0.061, p=0.993$, Fig B.6A) and c-cycling (ANOVA, winter: $F=0.039, p=0.997$; summer: $F=0.156, p$ $=0.958$, Fig. B.6B) functions did not differ significantly between the scenarios in either season. However, the biogenic habitat provision function differed significantly between the 5 scenarios (ANOVA, $F=8.659, p<0.0001$, Fig. B.5C) with scenario 1 to 4 differing significantly from scenario 5 $(p<0.05$, Table B.10).

The unconstrained estimates of nutrient cycling significantly differed between scenarios for model $B$ (ANOVA, winter: $F=3.197, p=0.030$, summer: $F=3.117, p=0.033$; Table B.10, Fig. B.7A). Nutrient cycling in scenario 3 and 4 were 5 fold higher in summer and 3 fold higher in winter compared to scenario 5. There were no significant differences observed for constrained density in both seasons.

Unconstrained estimates for c-cycling differed significantly between the 5 scenarios in model $B$ for both seasons (ANOVA, winter: $F=3.172, p=0.031$; summer: $F=3.128, p=0.032$; Table B.10, Fig. B.6B) but did not show a significant difference between the scenarios for constrained density (ANOVA, winter: $F=0.559, p=0.694$; summer: $F=1.782, p=0.164$; Table B.10, Fig.B.7D). The mean c-cycling was significantly higher in scenario 3 than in scenario 5 in for both seasons in model $B$ $(p<0.05)$.

Biogenic habitat provision (unconstrained and constrained estimates) significantly differed between scenarios, with scenarios 3 and 4 differing from scenario 5 in summer for model B unconstrained, and scenario 1 differing from scenario 5 for constrained model $B$ (ANOVA, unconstrained: $F=3.079$, $p=0.034$, Fig B.7E; constrained: $F=3.495, p=0.021$, Table B.10, Fig. B.7F).

Table B.10. Results of ANOVA and post-hoc tests (Tukey test or Mann-Whitney $\mathrm{U}^{1}$ ) to compare delivery of estimates for three ecological functions (e.g. nutrient cycling, c-cycling and biogenic habitat provision) in SE Queensland's southernmost 6 mudflats for the 5 scenarios. Models are based on trait modalities with affinities for each function (Model A) and application of differential weighting (Model B) (Table A.2). Hyphen indicates no post-hoc test because of non-significant ANOVA. The pairs that differed significantly $(p<0.05)$ are indicated in ${ }^{(*)}$ sign.

\begin{tabular}{|c|c|c|c|}
\hline Ecosystem function & & Winter & Summer \\
\hline \multicolumn{4}{|l|}{ Unconstrained density } \\
\hline \multirow[t]{8}{*}{ Nutrient cycling } & Model A ${ }^{1}$ & $F=2.868, p=0.044^{*}$ & $F=2.362, p=0.080$ \\
\hline & Scenario $1 \& 5$ & $Z=-2.402, p=0.016^{*}$ & - \\
\hline & Scenario $2 \& 5$ & $Z=-2.401, p=0.017^{*}$ & - \\
\hline & Scenario $3 \& 5$ & $Z=-2.565, p=0.010^{*}$ & - \\
\hline & Scenario $4 \& 5$ & $Z=-2.564, p=0.011^{*}$ & - \\
\hline & Model B & $F=3.197, p=0.030^{*}$ & $F=3.117, p=0.033^{*}$ \\
\hline & Scenario $3 \& 5$ & $p=0.043^{*}$ & $p=0.045^{*}$ \\
\hline & Scenario $4 \& 5$ & $p=0.05^{*}$ & $p=0.05^{*}$ \\
\hline \multirow[t]{5}{*}{ C-cycling } & Model A ${ }^{1}$ & $F=2.956, p=0.040^{*}$ & $F=2.301, p=0.087$ \\
\hline & Scenario $1 \& 5$ & $Z=-2.242, p=0.025^{*}$ & - \\
\hline & Scenario $2 \& 5$ & $Z=-2.244, p=0.026^{*}$ & - \\
\hline & Scenario $3 \& 5$ & $Z=-2.562, p=0.010^{*}$ & - \\
\hline & Scenario $4 \& 5$ & $Z=-2.563, p=0.011^{*}$ & - \\
\hline
\end{tabular}


[Type here]

\begin{tabular}{|c|c|c|c|}
\hline & $\frac{\text { Model B }}{\text { Scenario } 3 \& 5}$ & $\begin{array}{l}F=3.172, p=0.031^{*} \\
p=0.045^{*}\end{array}$ & $\begin{array}{l}F=3.128, p=0.032^{*} \\
p=0.044^{*}\end{array}$ \\
\hline \multirow[t]{2}{*}{$\begin{array}{l}\text { Biogenic habitat } \\
\text { provision }\end{array}$} & $\begin{array}{l}\frac{\text { Model A }}{\text { Scenario } 3 \& 5} \\
\text { Scenario } 4 \& 5\end{array}$ & $\begin{array}{l}F=2.266, p=0.091 \\
-\end{array}$ & $\begin{array}{l}F=4.240, p=0.009^{*} \\
p=0.046^{*} \\
p=0.046^{*}\end{array}$ \\
\hline & $\begin{array}{l}\frac{\text { Model B }}{\text { Scenario } 3 \& 5} \\
\text { Scenario } 4 \& 5\end{array}$ & $\begin{array}{l}F=1.753, p=0.170 \\
-\end{array}$ & $\begin{array}{l}F=3.079, p=0.034^{*} \\
p=0.049^{*} \\
p=0.049^{*}\end{array}$ \\
\hline \multicolumn{4}{|c|}{ Constrained density } \\
\hline Nutrient cycling & $\begin{array}{l}\text { Model A } \\
\text { Model B }\end{array}$ & $\begin{array}{l}F=0.294, p=0.879 \\
F=0.650, p=0.054\end{array}$ & $\begin{array}{l}F=0.061, p=0.993 \\
F=1.148, p=0.357\end{array}$ \\
\hline C-cycling & $\frac{\text { Model A }}{\text { Model B }}$ & $\begin{array}{l}F=0.039, p=0.997 \\
F=0.961, p=0.446\end{array}$ & $\begin{array}{l}F=0.156, p=0.958 \\
F=0.131, p=0.969\end{array}$ \\
\hline $\begin{array}{l}\text { Biogenic habitat } \\
\text { provision }\end{array}$ & $\begin{array}{l}\text { Model A } \\
\text { Scenario } 1 \& 5 \\
\text { Scenario } 2 \& 5 \\
\text { Scenario } 3 \& 5 \\
\text { Scenario } 4 \& 5\end{array}$ & $\begin{array}{l}F=1.442, p=0.250 \\
- \\
-\end{array}$ & $\begin{array}{l}F=8.659, p<0.0001^{*} \\
p<0.0001^{*} \\
p<0.0001^{*} \\
p=0.009^{*} \\
p=0.012^{*}\end{array}$ \\
\hline & $\frac{\text { Model B }}{\text { Scenario } 1 \& 5}$ & $\begin{array}{l}F=0.146, p=0.963 \\
-\end{array}$ & $\begin{array}{l}F=3.495, p=0.021^{*} \\
p<0.030^{*}\end{array}$ \\
\hline
\end{tabular}

${ }^{1}$ Post-hoc tests (Tukey, Student-Newman-Keuls) failed to identify pairwise differences between the scenarios, therefore Mann-Whitney $\mathrm{U}$ tests were performed (with Bonferroni correction) to identify which scenarios differed. 
[Type here]

A

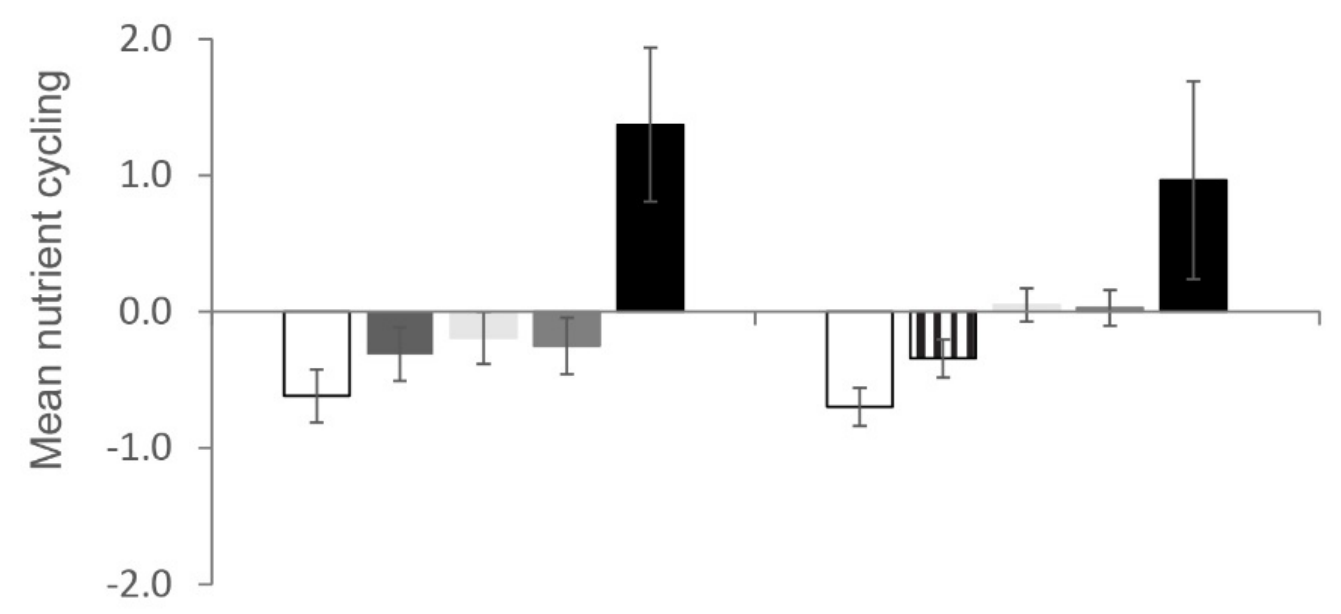

B

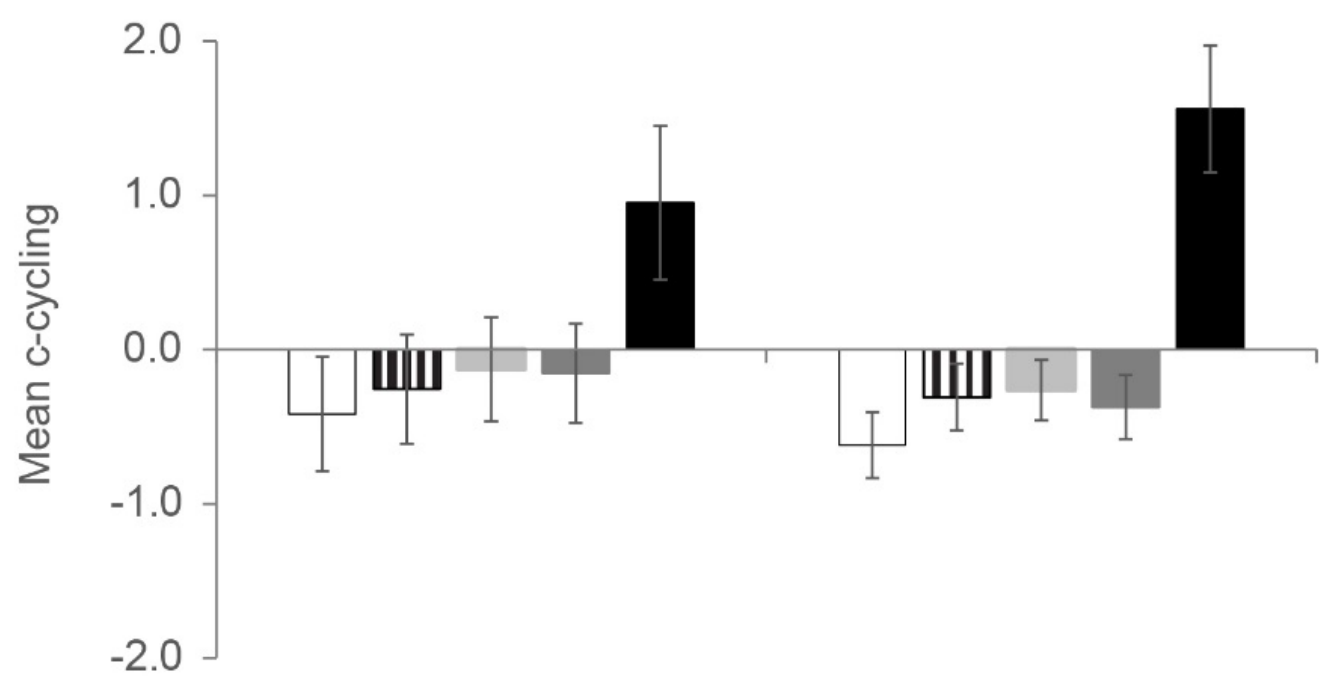

C

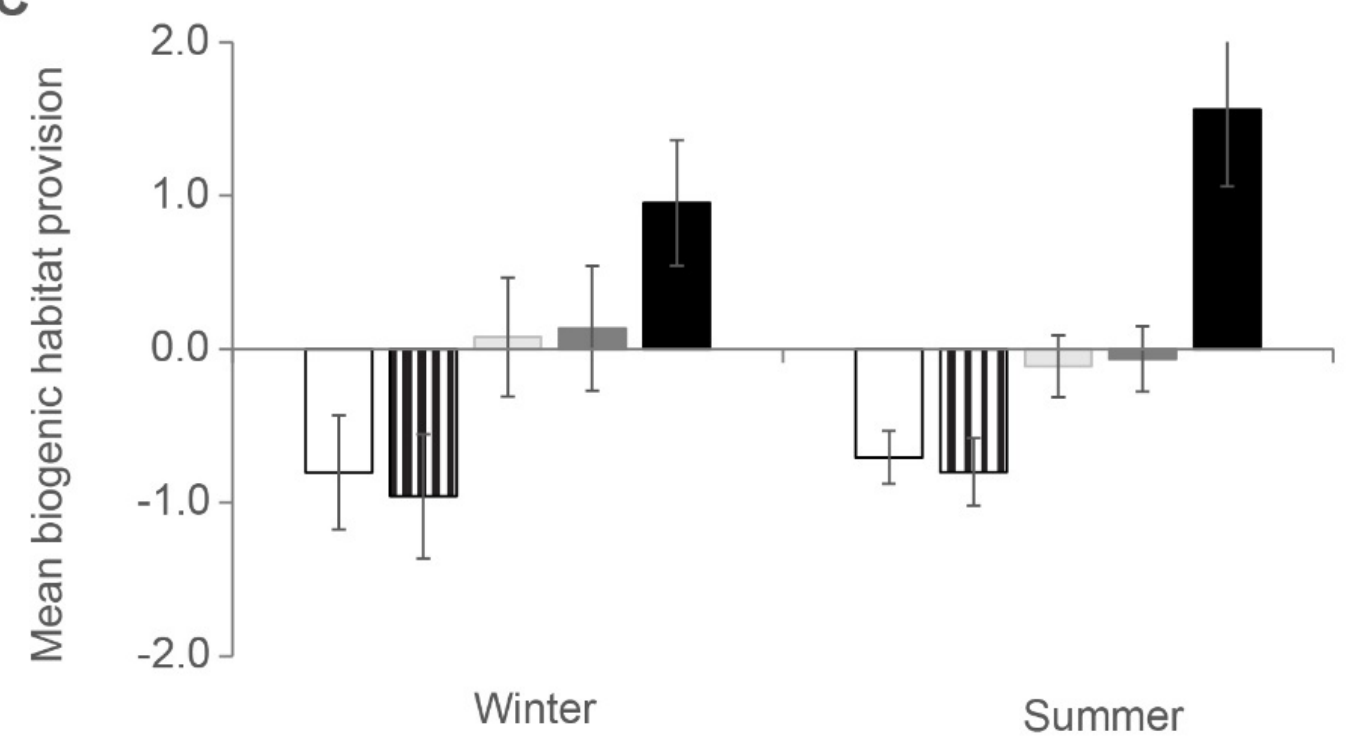

$\square$ Pre-invasion scenario $\square$ Baseline scenario

Further invasion scenario

Loss of sensitive temperate sp. scenario

Loss of all temperate sp. scenaro

Fig B.6. Delivery of three ecological functions (mean \pm SE of 6 sites) of the SE Queensland mudflats, standardised to zero mean and unit variance under five scenarios of species compositional change (A) nutrient cycling, (B) C-cycling and (C) biogenic habitat provision in model A (weighted by density constrained) in both winter and summer. For unconstrained estimates see Fig. 7 
[Type here]

A

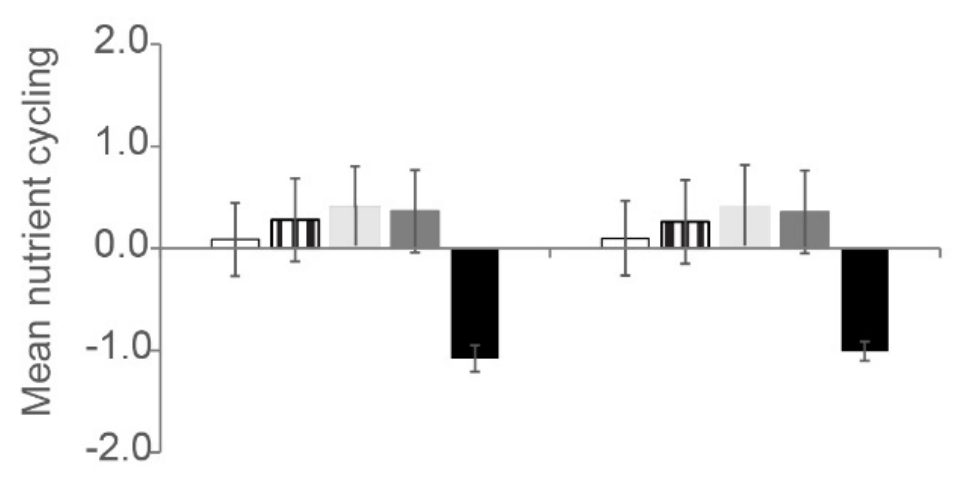

C

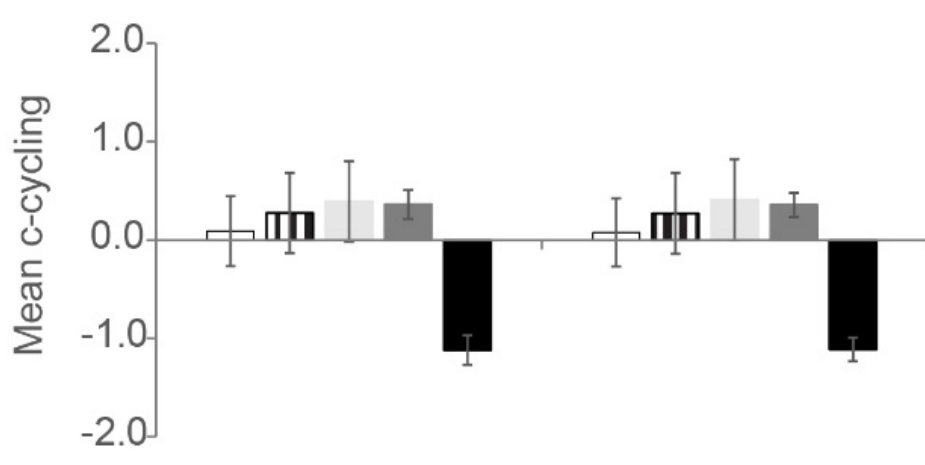

E

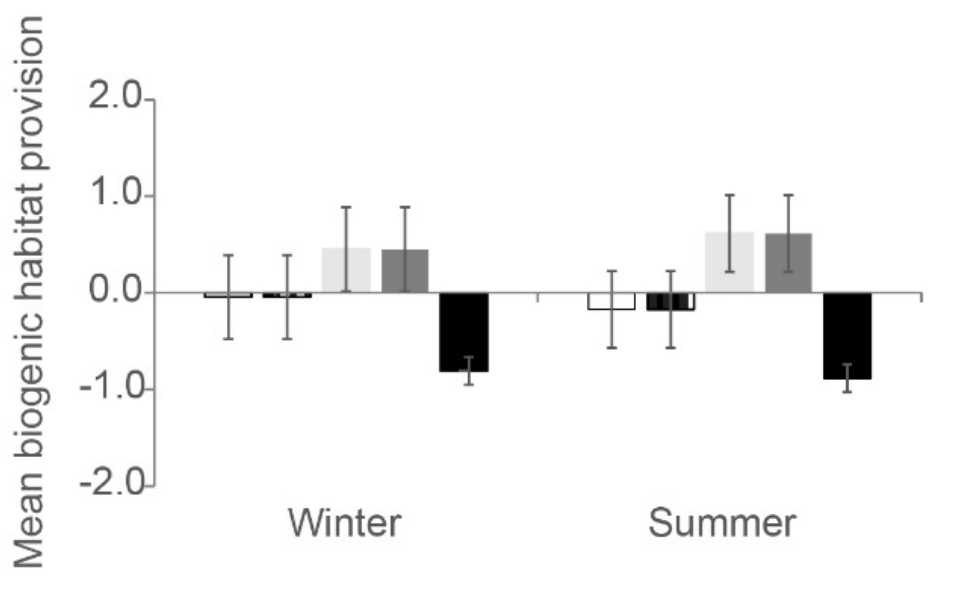

B

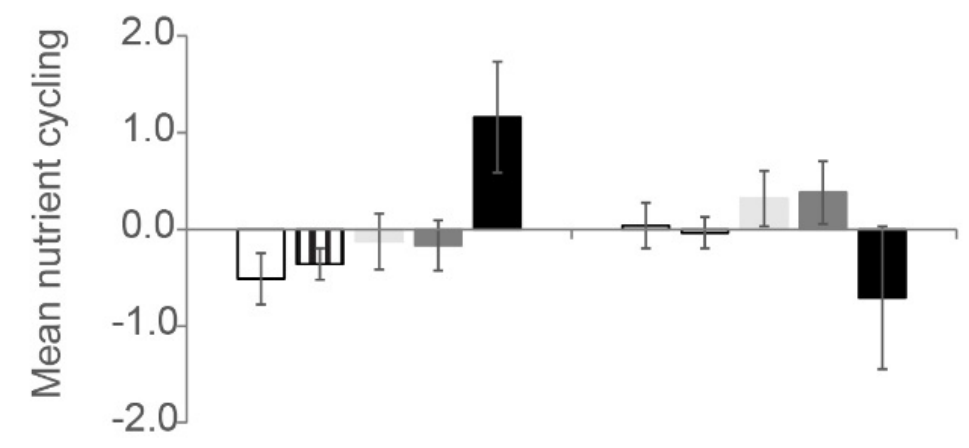

D

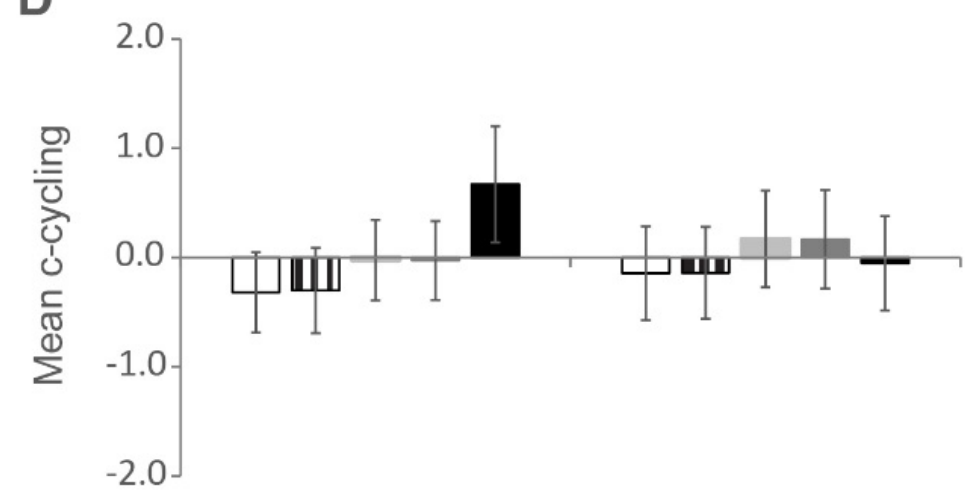

$\mathbf{F}$

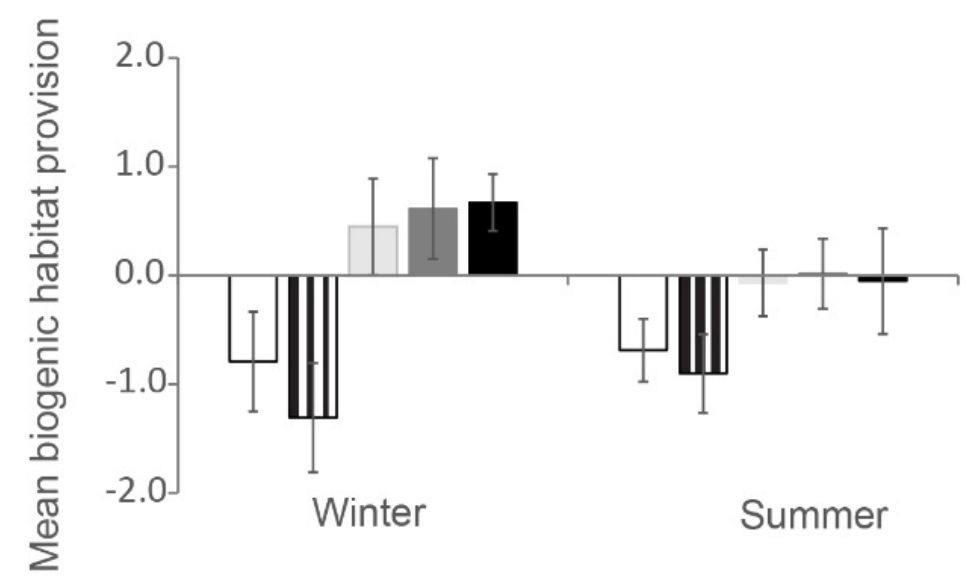

$\square$ Pre-invasion scenario $\square$ Baseline scenario $\square$ Further invasion scenario $\square$ Loss of sensitive temperate sp. scenario

Loss of all temperate sp. scenaro

Fig. B.7. Delivery of three of ecological functions (mean $\pm \mathrm{SE}$ ) of the SE Queensland mudflats, standardised to zero mean and unit variance under five scenarios of species compositional change (A) nutrient cycling density unconstrained, (B) nutrient cycling density constrained, (C) c-cycling density unconstrained, (D) and c-cycling density constrained (E) biogenic habitat provision density unconstrained and (F) biogenic habitat provision density constrained between the five scenarios in model $\mathbf{B}$ in both winter and summer.

\section{References}

ALA, 2018. Atlas of Living Australia, 16 November 2018 ed. Altas of Living Australia, Canberra, Australia.

Biles, C.L., Solan, M., Isaksson, I., Paterson, D.M., Emes, C., Raffaelli, D.G., 2003. Flow modifies the effect of biodiversity on ecosystem functioning: an in situ study of estuarine sediments. Journal of Experimental Marine Biology and Ecology:285, 165-177. 
Bolam, S.G., Fernandes, T.F., Huxham, M., 2002. Diversity, biomass, and ecosystem processes in the marine benthos. Ecological Monographs:72, 599-615.

Boulding, E.G., 1984. Crab-resistant features of shells of burrowing bivalves: decreasing vulnerability by increasing handling time. Journal of Experimental Marine Biology and Ecology:76, 201-223.

Bracken, M.E.S., 2018. When one foundation species supports another: Tubeworms facilitate an extensive kelp bed in a soft-sediment habitat. Ecosphere:9, e02429.

Branch, G.M., Pringle, A., 1987. The impact of the sand prawn Callianassa kraussi Stebbing on sediment turnover and on bacteria, meiofauna, and benthic microflora. Journal of Experimental Marine Biology and Ecology:107, 219-235.

Buhl-Mortensen, L., Vanreusel, A., Gooday, A.J., Levin, L.A., Priede, I.G., Buhl-Mortensen, P., Gheerardyn, H., King, N.J., Raes, M., 2010. Biological structures as a source of habitat heterogeneity and biodiversity on the deep ocean margins. Marine Ecology:31, 21-50.

Cetina-Heredia, P., Roughan, M., Van Sebille, E., Coleman, M., 2014. Long-term trends in the East Australian Current separation latitude and eddy driven transport. Journal of Geophysical Research: Oceans:119, 4351-4366.

Clare, D.S., Robinson, L.A., Frid, C.L.J., 2015. Community variability and ecological functioning: 40 years of change in the North Sea benthos. Marine Environmental Research:107, 2434.

D'Andrea, A.F., DeWitt, T.H., 2009. Geochemical ecosystem engineering by the mud shrimp Upogebia pugettensis (Crustacea: Thalassinidae) in Yaquina Bay, Oregon: Density-dependent effects on organic matter remineralization and nutrient cycling. Limnology and Oceanography:54, 19111932.

Dissanayake, N.G., Frid, C.L.J., Drylie, T.P., Caswell, B.A., 2018. Ecological functioning of mudflats: global analysis reveals both regional differences and widespread conservation of functioning. Marine Ecology Progress Series:604, 1-20.

Fenchel, T., 1996. Worm burrows and oxic microniches in marine sediments. 1. Spatial and temporal scales. Marine Biology:127, 289-295.

Fenchel, T., Finlay, B., 2008. Oxygen and the spatial structure of microbial communities. Biological Reviews:83, 553-569.

Frid, C.L.J., Caswell, B.A., 2016. Does ecological redundancy maintain functioning of marine benthos on centennial to millennial time scales? Marine Ecology:37, 392-410.

Greve, W., Reiners, F., Nast, J., Hoffmann, S., 2004. Helgoland Roads meso-and macrozooplankton time-series 1974 to 2004: lessons from 30 years of single spot, high frequency sampling at the only off-shore island of the North Sea. Helgoland Marine Research:58, 274-288.

Hansen, L.S., Blackburn, T.H., 1992. Mineralization budgets in sediment microcosms: effect of the infauna and anoxic conditions. FEMS microbiology ecology:11, 33-43.

Kristensen, E., Blackburn, T.H., 1987. The fate of organic carbon and nitrogen in experimental marine sediment systems: influence of bioturbation and anoxia. Journal of Marine Research:45, 231-257.

Kristensen, E., Penha-Lopes, G., Delefosse, M., Valdemarsen, T., Quintana, C.O., Banta, G.T., 2012. What is bioturbation? The need for a precise definition for fauna in aquatic sciences. Marine Ecology Progress Series:446, 285-302.

Mascaró, M., Seed, R., 2001. Choice of prey size and species in Carcinus maenas (L.) feeding on four bivalves of contrasting shell morphology, Advances in Decapod Crustacean Research. Springer, pp. 159-170.

Mermillod-Blondin, F., Rosenberg, R., FranÃfÂßois-Carcaillet, F., Norling, K., Mauclaire, L., 2004. Influence of bioturbation by three benthic infaunal species on microbial communities and biogeochemical processes in marine sediment. Aquatic Microbial Ecology:36, 271-284. 
Narayan, Y.R., Pandolfi, J.M., 2010. Benthic foraminiferal assemblages from Moreton Bay, South-East Queensland, Australia: Applications in monitoring water and substrate quality in subtropical estuarine environments. Marine Pollution Bulletin:60, 2062-2078.

Nates, S.F., Felder, D.L., 1998. Impacts of Burrowing Ghost Shrimp, Genus Lepidophthalmus Crustacea: Decapoda: Thalassinidea, on Penaeid Shrimp Culture. Journal of the World Aquaculture Society:29, 188-210.

Norkko, A., Villnäs, A., Norkko, J., Valanko, S., Pilditch, C., 2013. Size matters: implications of the loss of large individuals for ecosystem function. Scientific Reports:3, 26-46.

OBIS, 2018. Ocean Biogeographic Information System. International Oceanographic Data and Information Programme. Intergovernmental Oceanographic Commission of UNESCO.

Olafsson, E., 2003. Do macrofauna structure meiofauna assemblages in marine softbottoms? Vie Milieu:53, 249-265.

Penha-Lopes, G., Bartolini, F., Limbu, S., Cannicci, S., Kristensen, E., Paula, J., 2009. Are fiddler crabs potentially useful ecosystem engineers in mangrove wastewater wetlands? Marine Pollution Bulletin:58, 1694-1703.

Piepenburg, D., Blackburn, T H., Von Dorrien, C.F., Gutt, J.,, Hall, P.O.J., Hulth, S., Kendall, M.A., Opalinski, K.W., Rachor,, E., S., M.K., 1995. Partitioning of benthic community respiration in the Arctic (northwestern Barents Sea)'. Marine Ecology Progress Series:118, 199-213.

Rabaut, M., Guilini, K., Van Hoey, G., Vincx, M., Degraer, S., 2007. A bio-engineered softbottom environment: the impact of Lanice conchilega on the benthic species-specific densities and community structure. Estuarine, Coastal and Shelf Science:75, 525-536.

Smaal, A.C., Prins, T.C., 1993. The uptake of organic matter and the release of inorganic nutrients by bivalve suspension feeder beds, Bivalve filter feeders. Springer, Berlin, Heidelberg, pp. 271-298.

Spalding, M.D., Fox, H.E., Allen, G.R., Davidson, N., Ferdaña, Z.A., Finlayson, M., Halpern, B.S., Jorge, M.A., Lombana, A., Lourie, S.A., 2007. Marine ecoregions of the world: a bioregionalization of coastal and shelf areas. BioScience:57, 573-583.

Thomsen, M.S., McGlathery, K., 2005. Facilitation of macroalgae by the sedimentary tube forming polychaete Diopatra cuprea. Estuarine, Coastal and Shelf Science:62, 63-73.

Thrush, S.F., Hewitt, J.E., Gibbs, M., Lundquist, C., Norkko, A., 2006. Functional role of large organisms in intertidal communities: community effects and ecosystem function. Ecosystems:9, 1029-1040.

Van Oevelen, D., Soetaert, K., Middelburg, J.J., Herman, P.M.J., Moodley, L., Hamels, I., Moens, T., Heip, C.H.R., 2006. Carbon flows through a benthic food web: Integrating biomass, isotope and tracer data. Journal of Marine Research:64, 453-482.

Warwick, R.M., Clarke, K.R., 1984. Species size distributions in marine benthic communities. Oecologia:61, 32-41.

Welsh, D.T., 2003. It's a dirty job but someone has to do it: The role of marine benthic macrofauna in organic matter turnover and nutrient recycling to the water column. Chemistry and Ecology:19, 321-342.

Wilson, R.S., Cohen, B.F., Poore, G.C.B., 1993. The role of suspension-feeding and depositfeeding benthic macroinvertebrates in nutrient cycling in Port Phillip Bay. CSIRO, Melbourne, pp.

Worden, A.Z., Follows, M.J., Giovannoni, S.J., Wilken, S., Zimmerman, A.E., Keeling, P.J., 2015. Rethinking the marine carbon cycle: factoring in the multifarious lifestyles of microbes. Science:347, 1257594.

Zeuthen, E., 1953. Oxygen uptake as related to body size in organisms. The Quarterly review of biology:28, 1-12. 